\title{
${ }^{66}$ Even though I am Māori sometimes I feel like a bit of a fraud": Mixed-Race Māori Identity and The Influence of Legislation and Legal Administration c. 1850-1950
}

\author{
By \\ Kiriana Siobhan Haze \\ (Ngāti Pikiao, Te Arawa, Pākehā)
}

\begin{abstract}
A thesis
submitted to the Victoria University of Wellington in fulfilment of the requirements for the degree of

Master of Arts

in History
\end{abstract}

Victoria University of Wellington 


\begin{abstract}
In 1910, Āpirana Ngata stated that both he and the Young Maori Party were proponents for children born from a Māori - Pākehā mix. Ngata believed the children would then have the prime characteristics of each parent. This thesis explores how such rhetoric about mixed-race children was a consequence of the symbiotic influence Pākehā legislation and legal administration had on Māori identity. This influence was relevant to both mixed-race Māori historically, and today.
\end{abstract}

Too often, mixed-race people are questioned for their lack of authenticity. This questioning began the moment Pākehā people first came to New Zealand and courted interracial relations with Māori. Therefore, the period of 1850 to 1950 is where this thesis' substantive research and analysis lies as here the construction of legislation and legal administration to do with mixed-race Māori was most visible.

The themes this timeframe is considered through are 'marriage and land', 'native schools' and 'enumeration.' These themes are the best mechanism to display the ways in which the law has worked and continues to work to maintain a mixed-race dichotomy of privilege and disadvantage. This thesis draws on a wide range of legislative and administrative sources, to demonstrate the mentioned dichotomy crafted into the law. It contextualises these sources through consideration of existing literature, and oral interviews with self-identifying mixedrace Māori today. This work tracks Māori reclamation of the control to self-identify and the recurring indicators of colourism and dehumanisation which contributed to the speed bumps along this journey. 
In memory of my grandfather, Gerrit “Gerry" Haze.

I love you and I miss you, but I do not miss our driving lessons. 


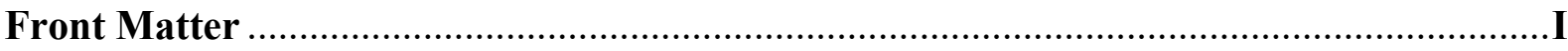

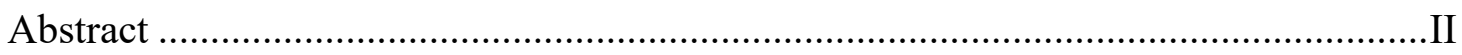

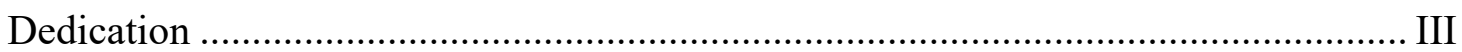

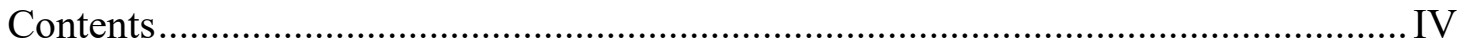

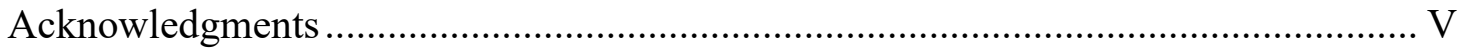

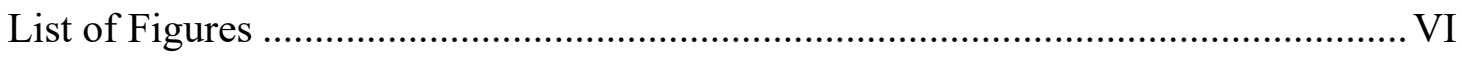

A Note on Terminology and Language ....................................................................

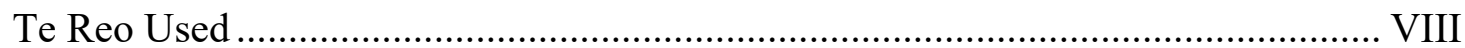

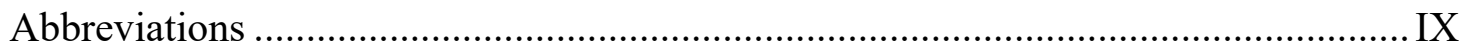

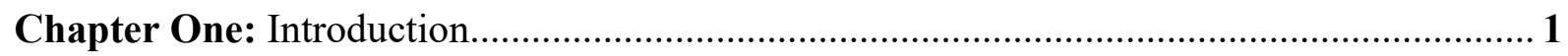

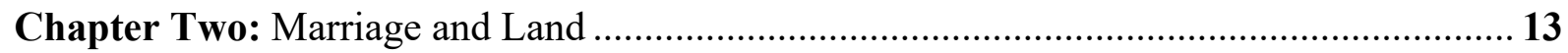

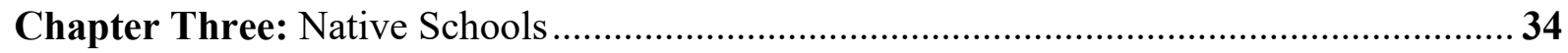

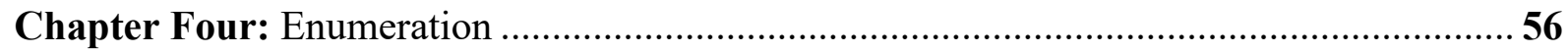

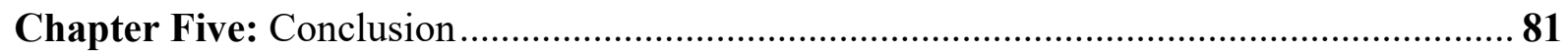

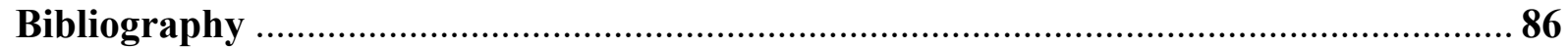




\section{Acknowledgements}

I would not have been able to complete this work without the generous support of so many people. Firstly, my supervisors, Professor Jim McAloon and Dr Arini Loader. You both told me that it will be both a blessing and a curse having two supervisors. I can only say that you both complemented each other so well and I always felt supported during this process. Arini, I am indebted to you for telling me to just "keep going" and to "feed" you more writing, no matter how much I resisted. Jim, I have always found your intelligence both amazing and intimidating but getting to know you has shown me that your kindness outshines that. I want to thank you both for your feedback, invaluable insights, and assistance in the development of this project. I look up to both of you.

To the academic and administrative staff in the Victoria University History Department, thank you for pretending not to see me pour staff-only milk into my coffee. I need to especially acknowledge Dr Cybèle Locke and Associate Professor Kate Hunter; it may not have been obvious but thank you both for making me recognise that history was something that I was OK at as a 19-year-old undergraduate. Without your initial push I would not have done this thesis. Also, Associate Professor Dolores Janiewski; thank you for the late night laughs while we both kept nocturnal hours in the department.

Thank you to my fabulous peers in the 2017 history honours cohort and the 2018/2019 history MA cohort. Particularly Rachel and Max for putting up with me in the master's office and starting before me. I believe they did this, so I knew what not to do, of which I then proceeded to do anyway. My gratitude goes to my proof-readers (Emma, Isabella, Rachel, Will, and Harriet) for your assistance in the editing stages. Errors that remain in this work are my own. The utmost appreciation must also go to my interviewees in this project; Chelsey, Jordan, Maddison, Matthew, Vanessa and Rhianna. Ultimately, this is for you.

To my Mum, Wendy, I owe you everything, all I ever want is for you to be proud of me. To my brother, Jamie, I have idolised you my entire life and your continuous belief (and annoyance) towards me has been (somewhat) appreciated. Thank you also to my extended family, best friends, and workplaces for being so accommodating during this period of my life. I must also mention my cats, past and present; Tom, Lucious, Penélope and O’Malley. 


\section{List of Figures}

Figure 1:

Page 1. 'Whymper' illustration featured in Arthur S. Thomson, The Story of New Zealand: Past and Present - Savage and Civilized, Volume 2 (London: John Murray, 1859), p. 306.

\section{Figure 2:}

Page 13. Alexander Cowan with his wife Mere (née Whakamairu) and son Peter. Iorns, Bennett, 1883-1977: Photographs relating to Masterton and the Wairarapa. Ref: PA1-q-13132-1. Alexander Turnbull Library, Wellington, New Zealand.

\section{Figure 3:}

Page 34. Illustration from Richard Taylor, The Past and Present of New Zealand; With its Prospects for the Future. With Numerous Illustrations, (London and New Zealand: William Macintosh and Henry Ireson Jones, 1868), p. 87.

\section{Figures 4, 5 and 6:}

Page 50. 'Table No. 3', 'Summary of Table No. 3', 'Table No. 8' from 'Education in Native Schools', AJHR, Session 2, E-3, 1909.

\section{Figure 7:}

Page 56. Jane Maria Gray with her children. Ref: 1/2-137188-F. Alexander Turnbull Library, Wellington, New Zealand. /records/23010883.

\section{Figure 8:}

Page 76. Te Arawa Iwi Registration Form as at 2019 from Te Arawa Lakes Trust: https://tearawa.iwi.nz/; accessed 1 July 2019.

\section{Figure 9:}

Page 81. Auckland Māori Community Centre, 1960s: Photograph by Ans Westra. Ref: AAMK W3495/28H. Archives New Zealand - Te Rua Mahara o te Kāwanatanga. 


\section{A Note on Terminology and Language:}

I am not fluent in te reo Māori. To the best of my ability throughout this work I have used macrons and spelling in accordance with 'Te Aka Māori-English, English-Māori Dictionary and Index.' ${ }^{1}$ I have kept source formatting when using direct quotes. I have omitted using macrons in my own writing when they were not used in their time (i.e. The Young Maori Party). I have refrained from using [sic] within quotations for te reo that is variable, or unconventional by current standards, but frequently used in their time (i.e. the pluralisation of Māori to 'Maories').

When talking about the children from interracial relationships I use the term 'mixedrace.' I will not use any other derivative. This is due to its current societal acceptance and negative connotations with other terms. When terms such as 'half-caste' are used it is solely attributed to the quote/context it is from.

This work will use the label 'Pākehā' to refer to 'European' or 'takata pora' unless quoted or contextually appropriate. 'Pākehā' encompasses white arrivals to New Zealand in the eighteenth and nineteenth centuries and their descendants. I do not use the term 'takata pora' or "people of the ships" which was popular with South Island iwi, Ngāi Tahu. 'Takata pora' referred to "strangers who were especially associated with the world of the ocean and with a European maritime technology." ${ }^{3}$ Its usage in the South Island was strong until the late nineteenth century when Pākehā became more commonly used. ' 'Pākehā' was in wide usage in the North Island from the outset of contact. Though not synonymous, it is not necessary for this thesis to differentiate the subtleties. Thus, I use Pākehā to encompass all white arrivals to New Zealand in the eighteenth and nineteenth centuries and their descendants.

\footnotetext{
1 John C Moorfield, Te Aka Māori-English, English-Māori Dictionary and Index, 3rd ed. (Auckland: Longman/Pearson Education, 2011).

2 Tony Ballantyne, Webs of Empire: Locating New Zealand's Colonial Past (Vancouver: UBC Press, 2014), p. 118.

${ }^{3}$ Tony Ballantyne, Webs of Empire, pp. 117-118.

${ }^{4}$ Tony Ballantyne, Webs of Empire, pp. 117-118.
} 


\section{Te Reo Used}

This glossary briefly details how this thesis has interpreted the te reo words it uses. Please note, often multiple meanings can be attributed to the words below and this list is not exhaustive.

Aotearoa - New Zealand.

Haka - ceremonial performance with actions and words.

Hāngī - earth oven.

Hapū - subsection of iwi.

Hui - gathering.

Iwi - group of people who share a common ancestor.

Kaumātua - a (usually older) person of status in a family (comparable to a patriarch/matriarch).

Kaupapa Māori - approaching topics with a Māori ideology, relevant to educational pedagogy in New Zealand.

Kīngitanga - King Movement with support from some Māori tribes to promote tino rangatiratanga.

Kotahitanga - Māori parliament, also 'togetherness'.

Kura - school.

Poi - a light ball on a string used in performance.

Tangata whenua - indigenous people of the land where their ancestors lived.

Te Reo - Māori language.

Taonga - treasured things of social, cultural or physical value.

Tapu - sacred.

Te Kōhanga Reo - Māori kindergarten/nursery.

Tūpuna - ancestors.

Tino rangatiratanga - Māori self-determination.

Wānanga - meeting to discuss.

Whakamā - ashamed, embarrassed, guilty.

Whakapapa - genealogy.

Whānau - family.

Whāngai - loosely translated to Māori customary adoption. 


\section{Abbreviations}

Appendix to the Journal of the House of Representatives (AJHR)

New Zealand Official Yearbooks (NZYB)

New Zealand Parliamentary Debates (NZPD)

The Appendix to the Journal of the Legislative Council (AJLC)

Victoria University of Wellington, New Zealand (VUW)

United States of America (USA)

New Zealand Legislative Council (NZLC) 


\section{Chapter One: Introduction}

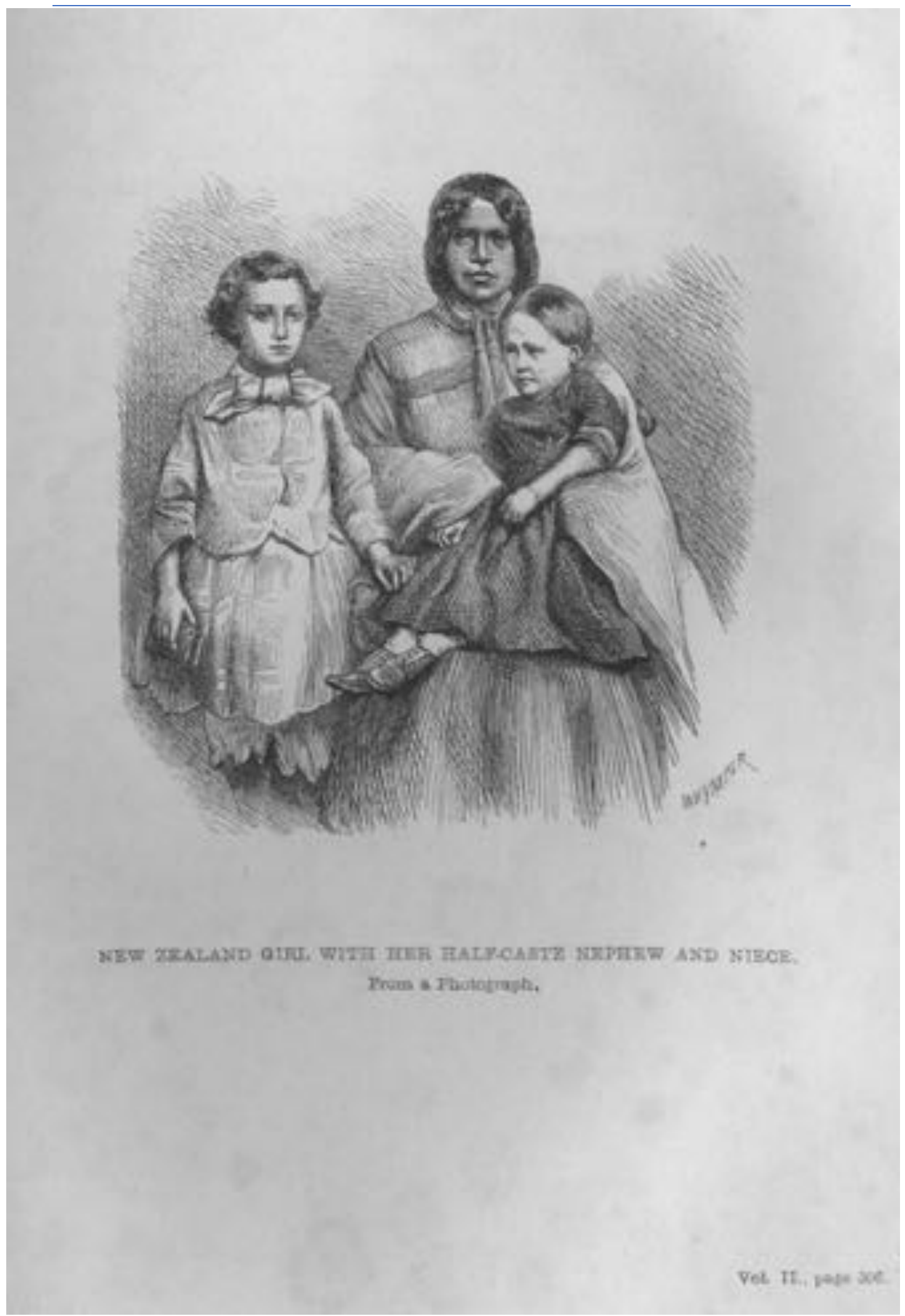

Figure 1. 'Whymper' illustration featured in Arthur S. Thomson, The Story of New Zealand: Past and Present - Savage and Civilized, Volume 2, (London: John Murray, 1859), p. 306. 


\section{Introduction}

An Oreo is a biscuit that has two circular chocolate wafers sandwiching a sweet crème filling. It is also what I used to be called in high school. According to my friends, I was brown (by a hair's breadth) on the outside and white on the inside. To be labelled after a 45-caloriecookie was something I was proud of. Sixteen-year-old me congratulated herself for overcoming her other 'half' and appearing white. Sixteen -year-old me was also an ignoramus; she thought she could not be both Pākehā and Māori and she did not arrive at that assumption by accident. The moment Pākehā arrived on New Zealand shores in the eighteenth century, mixed-race children were born, most definitely from the sexual, and possibly romantic, relations between Māori and Pākehā. There were never any laws forbidding these relationships, but racist legislation and legal administration were crafty. No matter the historic duplicity, looking back now it can be seen for what it is. The motivations behind, and consequences of, over two hundred years of assimilating and illegitimating is central to understanding the complexities behind mixed-race Māori identity, both historically and today.

I have chosen the period of c. 1850-1950 to base this thesis on because this is when construction of legislation and legal administration to do with mixed-race Māori was most visible. Mixed-race Māori were placed in a precarious position; to benefit through colourism, paternalism, infantilisation, and generations of legal privilege, while simultaneously not being able to inhabit Pākehā space comfortably. Due to having a long temporal scope I have restricted the analysis of this period in various ways. I have structured my chapters around legal processes concerning marriage, land, education, and enumeration. It must be stressed that, as this thesis considers the importance of identity, not all Māori identify as mixed-race. There are those who consider themselves as solely Māori, just as there are those who consider themselves as solely Pākehā (or another distinct group). My work does not concern itself with, or 'diagnose' a reason for this. Self-determination, in the way of self-identification, past and present will be accepted at face value. As stated, substantive analysis will be between c.1850-1950. Anything after this period is positioned to bridge the gap between 1950 to today. I have conducted oral interviews which appear at the end of each substantive chapter. Their placement is intended to generate correlations with the past to contextualise the present. The interviews offer insightful suggestions about how mixed-race identities are shaped now.

I have also limited my research to Māori/Pākehā mixed-race people. There are two reasons for this. Firstly, I do not feel it is appropriate to write a piece of identity history from a place I do not recognise. Kaupapa Māori was partly born out of "a prevailing sense of mistrust and wariness of Western research practices...from their ongoing interpretations of Māori 
reality, which have tended to misrepresent Māori..." I do not want to contribute to misinterpretation of a reality I do not come from. My mother is Pākehā and my father is Māori, they provided the foundation for my racial identification. It is necessary to recognise diversity within minorities and to do away with the interpretation of Māori as a homogenous group is necessary. It allows others, for example, Māori/Chinese or Māori/Samoan, the space and platform to research and write their truth and their perspective without the imposition of someone who is Māori/Pākehā "imposing their own constructions." "2 The second reason is that in the century following 1850, legal and administrative issues were almost all about the Māori - Pākehā mix.

\section{Theoretical Perspectives}

This research has been informed by socio-legal, colourism and Kaupapa Māori theories. The theories have organically intersected between each other and have influenced how I have gathered and considered various sources. Socio-legal theory is a growing idea that suggests that legal actions, as well as newspaper articles, disputes, and statistics about them, can influence identities. ${ }^{3}$ It argues that social history should be examined with the understanding that the law worked and continues to work in a way to engrain "multiple privileged and subordinate social and political statuses, differentiated according to characteristics such as lineage, caste and race."4 The majority of socio-legal theory is located in a United States historical context, however the basic premise that legal actions can and do "constitute aspects of social life, including... aspects of social identity" is what underpins discussions throughout this work. ${ }^{5}$

Colourism allows for the articulation of a social categorisation that has proved to be elusive to define and discuss. Little historical writing in New Zealand has been informed by colourism and how it helped to form interracial hierarchy and intra-racial racism. ${ }^{6}$ Colourism is not discussed so much in New Zealand due to the special pains taken to accommodate the principle set in 1974 that anyone with Māori heritage is entitled to identify as Māori. ${ }^{7}$ Despite this principle, colourism is still present and has been present for a long time and this thesis will

\footnotetext{
${ }^{1}$ Alayne Mikahere-Hall, 'Constructing Research from An Indigenous Kaupapa Māori Perspective: An Example of Decolonising Research', Psychotherapy and Politics International, Vol. 15, no. 3, October 2017, p. 3.

2 ibid, p. 4.

${ }^{3}$ Eric J. Mitnick, 'Law, Cognition, and Identity', Louisiana Law Review, Vol. 67, no. 3, September 2007, pp. 823869.

4 ibid, p. 824.

5 ibid, p. 823.

${ }^{6}$ For examples of work with meaningful discussions on colourism in New Zealand see: Tess Moeke-Maxwell, 'Bi/Multiracial Maori Women's Hybridity in Aotearoa/New Zealand', Discourses: Studies in the Cultural Politics of Education, Vol. 26, no. 4, 2005, pp. 497-510; Tahu H Kukutai, 'White Mothers, Brown Children: Ethnic Identification of Maori-European Children in New Zealand', Journal of Marriage and Family, Vol. 69, no. 5, 2007, pp. 1150-1161.

${ }^{7}$ Maori Affairs Amendment Act 1974.
} 
show that colourism was a real force in the century from 1850, and since 1974. While legal forms have denied its presence, it still has a legacy. I employ Margaret Hunter's definition of colourism being "a social process that privileges light-skinned people of colour over dark skinned people of colour in areas such as income, education, criminal justice sentencing, housing and the marriage market." ${ }^{8}$ Hunter continued that "people of color are often reluctant to discuss" colourism due to varying reasons including the shame of articulating inferiority. ${ }^{9} \mathrm{I}$ would add academics to the group of people reluctant to examine colourism in New Zealand which may be due to the popular perception that it is a process monopolised by black people and/or Latinx. ${ }^{10}$ Subsequently, there is substantial work that describes ideas of colourism and complexion, particularly in British and North American literature. ${ }^{11}$

Trina Jones, a law professor from the United States, has researched the ways in which colourism works within the law as a racial classifier. ${ }^{12}$ Jones argues that the law needs to understand how colourism works contemporarily and how it worked historically to understand the lack of equal opportunity. ${ }^{13}$ Colourism is not just imposed from outside groups, it is present and imposed within minority groups intra-racially. Aisha Phoenix's work on the politics of beauty and how colourism is a feminist issue shows this. Phoenix argues "people of colour are often complicit in the very colourism that disadvantages them, reproducing it in their treatment of other people of colour, including within their own families." ${ }^{14}$ In a New Zealand history context, colourism is heavily alluded to in nearly every piece regarding Māori-Pākehā relations, but very rarely is the label of colourism attributed to such dialogue, nor the intra-racial complexities of it. Tess Moeke-Maxwell has labelled colourism as something that was and still is a very active part in relations between Māori and regarding Māori. ${ }^{15}$ Moeke-Maxwell considers the issue of colourism and its association with culture in her work. Moeke-Maxwell states that colourism "functions metonymically to mark bi/multiracial women to particular

\footnotetext{
${ }^{8}$ Margaret Hunter, 'The Consequence of Colorism', in Ronald E Hall (ed.), The Melanin Millennium: Skin Color as $21^{\text {st }}$ Century International Discourse, (Dordrecht: Springer, 2013), p. 247.

9 ibid, p. 248.

10 ibid.

${ }^{11}$ Works about colourism and complexion include but are not limited to: Deborah Gabriel, Layers of Blackness: Colourism in the African Diaspora, (London: Imani Media, 2007); Evelyn Nakano Glenn (ed.), Shades of Difference: Why Skin Color Matters, (Santa Clara: Stanford University Press, 2009); Margaret L. Hunter, Race, Gender and the Politics of Skin Tone, (New York: Routledge, 2005); Meeta Rani Jha, The Global Beauty Industry: Colourism, Racism, and the National Body, (Oxford: Taylor \& Francis, 2015); Ronald E Hall (ed.), The Melanin Millennium: Skin Color as 21 ${ }^{\text {st }}$ Century International Discourse, (Dordrecht: Springer, 2013); Stephanie Rose Bird, Light, Bright, and Damned Near White: Biracial and Triracial Culture in America, (Santa Barbara: Greenwood Publishing Group, 2009); Winifred Barbee, Coming Aware of Our Multiraciality: The Politics of Skin Color, (Colorado: Outskirts Press, 2006).

12 Trina Jones, 'Shades of Brown: The Law of Skin Color', Duke Law Journal, Vol. 49, 2000, pp. 1487-1557.

${ }^{13}$ Ibid.

${ }^{14}$ Aisha Phoenix, 'Colourism and the Politics of Beauty', Feminist Review, Vol. 108, no. 1, 2014, p. 103.

15 Tess Moeke-Maxwell, 'Bi/Multiracial Maori Women's Hybridity in Aotearoa/New Zealand', p. 505.
} 
spaces and places."16 This aligns with Hunter's description that to understand colourism is to understand that "the racialized features of the body are embedded with racial meanings and cues about civility, modernity, virtue, and beauty."17

To further understand Māori identity in multiple ways and in multiple spaces it is appropriate to use Kaupapa Māori. Kaupapa Māori is defined by Leonie Pihama as a theory which has "grown from Māori struggles for tino rangatiratanga and mana motuhake... As such there is a clear cultural and political intent... The idea that theorists and researchers are acultural is directly challenged by the assertion of indigenous theories, such as Kaupapa Māori, that are grounded within cultural frameworks and epistemologies." 18 What this theory brings to my thesis is the validation of multiple Māori experiences. Though its genesis is within educational scholarship, as Pihama states, its use can and should be far-reaching in academia, as it was never intended to be prescriptive:

Kaupapa Māori theoretical framework must be cognisant of our historical and cultural realities, in all their complexities...a common complaint by Māori students is regarding the inaccessibility of some theoretical discussions...this is especially relevant to Kaupapa Māori theory as its sustainability is dependent on its reproduction by Māori for Māori. To write in ways that deny access to the majority of Māori people is in my opinion bringing closure rather than ensuring ongoing debate and evolution. ${ }^{19}$

This thesis' interpretation of Kaupapa Māori is that it is a theoretical paradigm that has evolved to welcome discussion, debate and transformation through the inclusion of Māori who also identify as Pākehā. I resist the Western hegemonic theorisation standard, which acts to exclude indigenous experiences.

\section{Methodology}

I am not using oral history methodology ornamentally. As a methodology, it allows for the researcher to "establish meaning for events." 20 By this, I mean what happened in the past still means something and it still matters because people are still hurting over it. The oral histories in this research were conducted with the innate understanding that what is being told is special, like Judith Binney states: "it is their history." ${ }^{21}$ Consequently, minorities can reclaim

\footnotetext{
${ }^{16}$ Ibid.

${ }^{17}$ Margaret Hunter, ‘The Consequence of Colorism', p. 249.

${ }^{18}$ Leonie Pihama, 'Kaupapa Māori Theory: Transforming Theory in Aotearoa', in Leonie Pihama, Sarah-Jane Tiakiwai, and Kim Southey (eds.), Kaupapa Rangahau: A Reader, (Hamilton: Te Kotahi Research Institute, 2015), p. 6.

19 ibid, pp. 9-10.

${ }^{20}$ Judith Binney, Stories Without End: Essays 1975-2010, (Wellington: Bridget Williams Books, 2010), p. 83.

${ }^{21}$ Italicisation of 'their' attributed to Judith Binney, Stories Without End, p. 83.
} 
the popular canon of New Zealand history by shifting the focus from outsider to insider knowledge about how colonialism has contributed to the narratives that the interviewees share. This is, of course, a major question of this work; the influence of the past on the present. Despite most of my interviewees missing an in-depth knowledge of New Zealand legislation and legal administration, what they could articulate was their emotions. No matter how unrefined their articulations were, their importance was unquestionable. Binney explained her management of oral histories which reinforced the approach I took to the methodology:

The integrity of the various oral histories has to be retained when they are transmitted in a written form...The contradictions in what constitutes history - oral and written - cannot be resolved. We cannot translate other histories into our own. We can merely juxtapose them. The structures and the events have been bonded, culturally, in time place...Maori oral narrative histories convey what is seen to be the essence of human experience to the people who are living... The 'telling of history', whether it be oral or written, is not and never has been neutral. It is always the reflection of the priorities of the narrators and their perceptions of their world..$^{22}$

I have conducted six oral interviews with self-identified mixed-race Māori. The interviewees vary in age, gender and sexual identities. Binney's explanation relates to this thesis as during the interview process there was constant acknowledgment of individual experiences being loaded with political and personal meaning - neutrality was not present. I asked the interviewees questions to consider who they are and how they identify. This was important to outline as "the ways that people who occupy a potentially ambiguous space between categories may fashion their identities from multiple sources to produce the outcome they desire." ${ }^{23}$ The interviewees were also asked for their thoughts and opinions on themes related to the main categories of my chapters.

All the interviewees in this work have agreed for their real names to be used. They are: Maddison Huaana Baker (Ngāti Kahungunu ki Wairarapa, Ngāti Porou, Ngāi Tahu, Pākehā), Jordan Letitia Bougen (Te Rarawa, Te Aupōuri, Pākehā), Chelsey Hine Te Aroha Brown (Ngāti Tūwharetoa, Ngāti Porou), Vanessa Jaye Immink (Ngā Waiariki Ngāti Apa, Ngāti Hauā, Tūwharetoa, Pākehā), Matthew Lambert (Ngāti Kahungunu), and Rhianna Eve Morar (Tapuika, Ngāti Porou, Pākehā, Indian). I will refer to them using their first names throughout this work.

22 Judith Binney, Stories Without End, p. 85.

${ }^{23}$ Emma Kowal, 'Descent, Classification and Indigeneity in Australia', in Kirsten McGavin and Farida Fozdar (eds.), Mixed Race Identities in Australia, New Zealand and the Pacific Islands, (New York: Routledge, 2017), p. 20. 
The interviewees in this thesis are people with whom I am friends. Their agreement to be interviewed stemmed from the fact that through friendship, I have learnt that these people selfidentify as mixed-race Māori and they were willing to explore their experiences. I have inserted myself into this research by this fact, alongside researching and writing this work. I care about these people and I care about the shared experience of being mixed-race. I do not see this as a detriment as it has allowed for the interview experience to be collaborative and has made me aware of my own subjectivities, such as the relationship between the interviewer and interviewee informing what is discussed and the outcome of the information given.

Alongside the interviews, this work makes use of legislation and legal administration sources. To contextualise pieces of legislation, I use the of Appendix to the Journal of the House of Representatives (AJHR), New Zealand Official Yearbooks (NZYB), New Zealand Gazettes, New Zealand Parliamentary Debates (NZPD), the Appendix to the Journal of the Legislative Council (AJLC), and newspaper articles. In terms of legal administration, past survey forms and reports from Native Affairs, Statistic New Zealand, and native school inspectors have been used. There is also use of New Zealand case law, Education Department resources, and active iwi websites.

\section{Historiography}

New Zealand historiography on mixed-race children is focused on the parents of the offspring rather than the offspring themselves. An historiography of existing New Zealand mixed-race literature would be incomplete without the inclusion of Ngāi Tahu academics Atholl Anderson, Tipene O'Regan, Hana O'Regan and Angela Wanhalla. I use Ngāi Tahu because the contact period with Pākehā in the South Island began far earlier and the contact was far closer than what occurred in the North Island. ${ }^{24}$ Hana O'Regan describes the legacy that Pākehā/Māori procreation has had on the South Island iwi, stating, "they have had generations of being talked about as being 'not real Māori', 'plastic Māori', 'inadequate', and 'culturally incompetent.",25

Atholl Anderson has done extensive research on Māori-Pākehā families by tracing the population growth of Pākehā and the corresponding decrease of Māori in the South Island during the nineteenth century. ${ }^{26}$ Anderson believes that the most obvious effect of colonisation was the loss of culture and tradition due to population decrease, "the most difficult of historical trends to measure." ${ }^{27}$ Anderson's work shows how the preoccupation with terms such as 'fullblooded' or 'half-caste' has continued long after the accuracy of the labels. Most useful to my

\footnotetext{
24 Tipene O'Regan, 'Old Myths and New Politics. Some Contemporary Uses of Traditional History', The New Zealand Journal of History, Vol. 26, no. 1, 1992, p. 7.

${ }^{25}$ Hana O’Regan, Ko Tahu, Ko Au: Kāi Tahu Tribal Identity, (Wellington: Horomaka Publishing, 2001), p. 141.

${ }^{26}$ Atholl Anderson, Race Against Time: The Early Māori-Pākehā Families and the Development of the MixedRace Population in Southern New Zealand, (Dunedin: Otago University Press, 1991).

27 ibid, p. 186.
} 
work were the discussions on the influence of religion and Bishop Selwyn's belief that bilingual children "taught their mothers Pakeha ways and thus helped bridge the cultural divide." 28 Throughout the entirety of Anderson's work, the notion of mixed-race children being praised as tools of assimilation and the legislative preparation for them to occupy a liminal position is persistently seen.

Angela Wanhalla is one of New Zealand's most prolific historians in the field of Māori and Pākehā relationships. ${ }^{29}$ Wanhalla's work is predominantly focused on nineteenth century relations between Pākehā men and Māori women in the South Island. To contextualise Wanhalla's work, the attention she gives to race, and intimacy, is often connected to Ngāi Tahu history. This is important to note as throughout this thesis it will be shown that the South Island situation was very different to the North Island situation when it came to interracial relations. Wanhalla's work questions how strong the argument is for Māori and Pākehā existing in different worlds when there has been over 200 years of contact in different communities which says otherwise. This thesis extends what Wanhalla has done to consider what marriage legislation meant for the children of interracial relationships.

Samoan New Zealand academic Damon Salesa has done extensive work on race relations and intermarriage which has been influential in increasing my interest in this topic and the complexities behind policy and ideology to do with hybridity. Salesa's research outlines the importance of letting go of any preconceived notions of miscegenation. ${ }^{30}$ The British Empire was not the United States of America (USA), and although the USA's race relations dominate much current-day media, historically New Zealand identity was connected to being a British settler colony. ${ }^{31}$ The intentions of the British Empire during my research's focus period involve a more horizontal rather than vertical integration which influenced the legislation and legal administration implemented throughout the dominions. The British Empire's horizontal integration via colonisation of land that was already occupied by indigenous peoples was complex. For example, New Zealand found it difficult to make any laws against Indian

\footnotetext{
28 ibid, pp. 195, 214.

29 Angela Wanhalla, Matters of the Heart, (Auckland: Auckland University Press, 2013); Angela Wanhalla, In/Visible Sight, (Wellington: Bridget Williams Books, 2009); Angela Wanhalla, 'Rethinking 'Squaw Men' and 'Pakeha-Maori': Legislating White Masculinity in New Zealand and Canada, 1840-1900', in Leigh Boucher, Jane Carey, Katherine Ellinghaus (eds.), Re-Orienting Whiteness, (New York: Palgrave Macmillan, 2009); Angela Wanhalla, 'Interracial Sexual Violence in 1860s New Zealand', The New Zealand Journal of History, Vol. 45, no. 1, 2011, pp. 71.84; Angela Wanhalla, 'The Politics of 'Periodical Counting': Race, Place and identity in Southern New Zealand', in Tracey Banivanua Mar and Penelope Edmonds (eds.), Making Settler Colonial Space, (London: Palgrave Macmillan, 2010); Angela Wanhalla, 'Transgressing Boundaries: A History of the Mixed Descent Families of Maitapapa, Taieri, 1830-1940', PhD Thesis, University of Canterbury, 2004.

${ }^{30}$ Damon Salesa, Racial Crossings: Race, Intermarriage, and the Victorian British Empire, (New York: Oxford University Press, 2011).

31 ibid.
} 
immigration, despite concerns about racial crossing, since the British had colonised India and as such, were British subjects. ${ }^{32}$ Salesa states:

These were not matters that could be easily banished by blunt laws, simple declarations, or spuriously engineered ideas, nor could they be controlled or ordered by policy or official fiat. Interest in racial crossing did not always manifest blatantly, and was as often chronic as it was acute, insinuated into policy and other techniques of governmental and social management. The complexity of all that came to overlay and underpin the practices, discourses and experiences of race crossing is richly revealing of British, imperial and colonial histories. ${ }^{33}$

Kate Riddell, through her consideration of New Zealand data collection methods in relation to intermarriage, focused on investigating intermarriages' link to societal opinion on the survival of the Māori population post-contact. ${ }^{34}$ Unlike Riddell, this research moves away from 'popular' or 'Pākehā' views towards a more inward-looking approach to enumeration and its role in influencing how Māori self-define. Lachy Paterson disrupts the popular contact narrative of Māori passivity to colonisation through Māori language newspapers, propaganda from the government, various religious denominations and the Kingitanga. ${ }^{35}$ Despite the intent of the Māori newspapers to disseminate colonial news, they were also an opportunity for Māori to constructively discuss and argue issues that affected Māori on a public platform. ${ }^{36}$ John Barrington and Kuni Jenkins' work on Māori in the education system is useful to consider alongside legislation concerning native schools in the century following $1850 .{ }^{37}$ Ian Pool's extensively detailed demography of New Zealand's population was the influence behind the enumeration chapter's argument that population statistics are as dynamic as the people they count. ${ }^{38}$

\footnotetext{
32 Jane McCabe, 'Working the Permit System: Anglo-Indian Immigration to New Zealand, 1920-1940', New Zealand Journal of History, Vol. 48, no. 2, 2014, pp. 27-49.

${ }^{33}$ Damon Salesa, Racial Crossings, p. 1.

${ }^{34}$ Kate Riddell, “Improving' the Maori: Counting The Ideology of Intermarriage”, New Zealand Journal of History, Vol. 34, No. 1, 2000, pp. 80-97.

${ }^{35}$ Lachy Paterson, 'Hāwhekaihe: Māori Voice on the Position of 'Half-Castes' within Māori Society', Journal of New Zealand Studies, Vol. 9, March 2010, pp. 135-156

36 ibid, pp. 135-156

${ }^{37}$ John Barrington, and T.H. Beaglehole, Maori Schools in a Changing Society, (Wellington: New Zealand Council for Education Research, 1974); John Barrington, Separate but Equal? Māori Schools and the Crown 1867-1969, (Wellington: Victoria University Press, 2008); John Barrington, Maori and the State: Crown-Māori Relations in New Zealand/Aotearoa, 1950-2000, (Wellington: Victoria University Press, 2009); Kuni Jenkins, 'Becoming Literate - Becoming English, A Research into The Beginnings of English Literacy Within Maori Society', (Auckland: Monograph, University of Auckland, 1993); Kuni Jenkins and Kay Morris Matthews, Hukarere and the Politics of Maori Girls 'Schooling 1875-1995, (Auckland: The Dunmore Press, 1995).

38 Ian Pool, Te Iwi Maori: A New Zealand Population Past, Present and Projected, (Auckland: Auckland University Press, 1991).
} 
The children of interracial unions are well studied in an international context. As Wanhalla does, Daniel Livesay, Justin Nystrom, and Tony Austin have used sources including probates, marriage certificates and laws enacted about (or against) mixed-race children in British, USA and Australian contexts. ${ }^{39}$ Livesay and Austin look at how legal documents and racial ideologies can create a context of mixed-race children brought up in a world that constantly negotiates their identities for them. ${ }^{40}$ Wherever white settlers went, so too did a preoccupation with race-mixing. There were the "Cape Coloureds', the Métis of Canada, the Eurasians of India, the half-castes in New Zealand, or the smallest and perhaps most fetishized population, the descendants of the Bounty mutineers discovered on Pitcairn Island." 41

Paul Lachance has done research on how a "Three-Caste Society" can be formed with mixed-race children attaining class mobility through inheritance during and after the reconstruction era in New Orleans, Louisiana. ${ }^{42}$ The probates of white men who became fathers from their involvement in sexual relationships with free black women give insight into New Orleans' mixed-race children. ${ }^{43}$ Children from such relations who inherited land, possessions, and/or money through their white fathers' last will and testament meant that they were better off financially and socially. Most of all, the mixed-race children would have the social benefit of being claimed and recognised as a white man's child. ${ }^{44}$ Although these children were better off than black people, they were also in a society where privilege was afforded by whites, creating a pseudo-elitism and a skewed mentality surrounding colourism, social status and class. ${ }^{45}$

As the international contexts have shown, mixed-race peoples all over the world have faced similar impacts from colonisation and assimilation. The justification for this thesis giving less attention to the international exchange of colonial ideals is that the differences are as important as the similarities of minority oppression. As Salesa explains, "the differences are too important or too large, the political, social and cultural landscapes - and, of course, the individuals - too different." 46 So while not featured greatly, the literature available on

39 Daniel Livesay, Children of Uncertain Fortune: Mixed-Race Jamaicans in Britain and the Atlantic Family, 1733-1833, (Chapel Hill: North Carolina Press, 2018); Justin Nystrom, 'In My Father's House: Relationships and Identity in an Interracial New Orleans Creole Family, 1845-1875', Louisiana History: The Journal of the Louisiana Historical Association, Vol. 49, no. 3, 2008, pp. 287-313; Tony Austin, 'Cecil Cook, Scientific Thought and 'Half-Castes' In the Northern Territory 1927-1939', Aboriginal History, Vol. 14, no. 1, 1990, pp. 104-122.

${ }^{40}$ Daniel Livesay, Children of Uncertain Fortune: Mixed-Race Jamaicans in Britain and the Atlantic Family, 1733-1833, pp. 8-9; Justin Nystrom, 'In My Father's House: Relationships and Identity in an Interracial New Orleans Creole Family, 1845-1875', pp. 304-305.

${ }^{41}$ Damon Salesa, Racial Crossings, p. 7.

${ }^{42}$ Paul Lachance, 'The Formation of a Three-Caste Society: Evidence from Wills in Antebellum New Orleans', Social Science History, Vol. 18, no. 2, Summer 1994, pp. 211-242.

43 ibid.

44 ibid.

45 ibid

${ }^{46}$ Damon Salesa, Racial Crossings, p. 2. 
mixed-race history should be considered in the sense that these issues are not isolated to New Zealand. The way others have considered mixed-race in their respective countries matters to evaluate how to consider New Zealand.

\section{Chapters}

The three substantive chapters of this thesis deal with, in the following order, 'marriage and land', 'native schools', and 'enumeration'. These themes are the best mechanism to display the ways in which the law has worked and continues to work to maintain a mixed-race dichotomy of privilege and disadvantage. They have been ordered this way to thematically represent the coming together of parents to create a child, the education of a child and, finally, how one is counted. Chapter two on marriage and land pieces together the idea that interracial couples and mixed-race children had a price to pay that was greater than that of land. This chapter is about the consequences thrust upon the children of such unions. It considers the origins of mixed-race children in both the literal and legislative sense to see how the laws behind marriage and land are inextricably connected to mixed-race Māori. Chapter three on native schools establishes how the education system has influenced Māori self-worth historically through to today. The system itself was a paradox, as the ethnic, racial and class ranking meant a simultaneous inclusion and exclusion of mixed-race children. The children were provided opportunities by the education system, but these often came with caveats. Chapter four on enumeration considers the influence of the 'encounter narrative' between Māori and Pākehā and its reflection in enumeration and immigration policy. Pākehā used enumeration to create an ancestral identity they were comfortable with at the expense of mixed-race identity. This chapter's underlying argument is that a census or any method of enumeration is not objective and can be a tool for erasure. How one is enumerated teaches us a lot about how Māori interpret themselves. Blood quantum, Māori culture and physiognomy feature heavily in this chapter as years of enumeration based on these qualifiers have shaped Pākehā and Māori opinion on Māori identity, as we have all been affected by these activities and ideas.

\section{Outcome}

The title of this work comes from interviewee, Maddison, saying "even though I am Māori sometimes I feel like a bit of a fraud." ${ }^{47}$ The sense of discomfort and emotion in the interview made it clear what this work needed to achieve. The term 'half-caste' and its use in the law in the century after 1850 cannot and should not be considered only in historical terms. This is because the history is still producing very real consequences. Maybe in 100 years

\footnotetext{
${ }^{47}$ Maddison Baker interview conducted by Kiriana Haze, 14 March 2019, Wellington, New Zealand.
} 
saying 'mixed-race' will feel wrong, the linguistics will have evolved, and future scholars and society will be able to define those of Māori descent with more nuance. For now, the term 'mixed-race' feels appropriate as it represents a mixed bag of historical, emotional trauma felt all over the country today. 


\section{Chapter Two: Marriage and Land}

Normally understood as extending the rule of law, commerce and Christianity into Māori communities, racial amalgamation also ideally functioned to bring about the creation of 'one people' through social intermixing, including interracial marriage.

-Angela Wanhalla. ${ }^{1}$

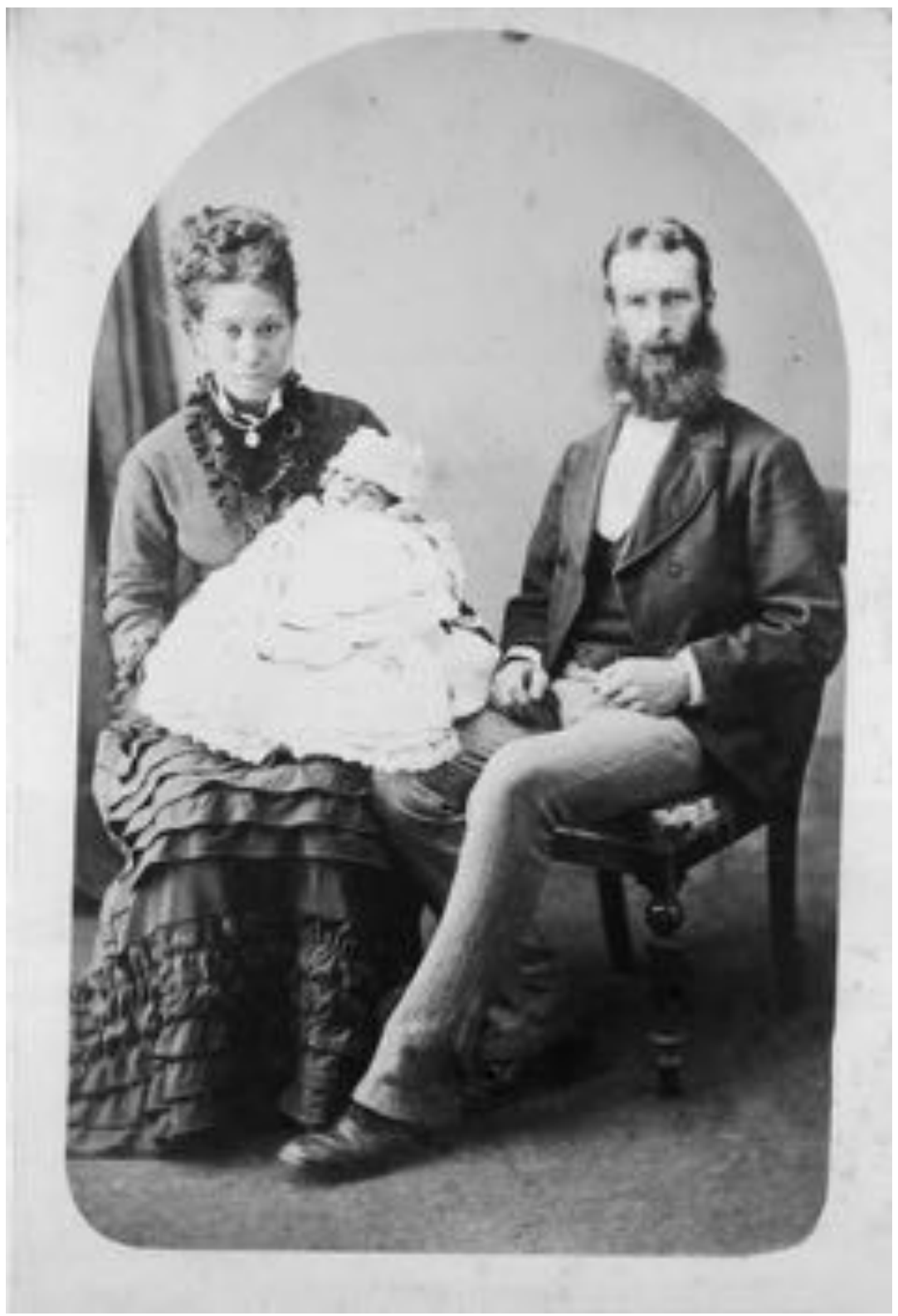

Figure 2. Alexander Cowan with his wife Mere (née Whakamairu) and son Peter. Iorns, Bennett, 1883-1977: Photographs relating to Masterton and the Wairarapa. Ref: PA1-q-131-32-1. Alexander Turnbull Library, Wellington, New Zealand.

\footnotetext{
${ }^{1}$ Angela Wanhalla, Matters of the Heart, (Auckland: Auckland University Press, 2013), p.47.
} 


\section{Introduction}

Interracial marriage has never been prohibited in New Zealand. But marriages laws were still a colonising tool used to remove both custom and land. This chapter maps this removal in legislation and legal administration c.1850-1950 in relation to mixed-race Māori. The law reinforced popular Pākehā ideology where mixed-race Māori children were to be considered 'better' than 'full' Māori. This is despite the children being touted by Pākehā as 'the solution for the world's racist problems in a vacant celebration of sanitized cultural hybridity." 2 In actuality, mixed-race children were made "intelligible in ways that maintain racial hierarchy" in legislation, rather than in ways which erase colour. ${ }^{3}$ Light brown children in dark brown communities were increasingly present and were representative of a change to "the boundaries which demarcate Pākehā and Māori sanctioned landscapes."4 This chapter will show the complexity in the treatment of mixed-race children through infantilization and paternalism, alongside dehumanisation and amalgamation tactics. Through this treatment, the idea of 'caste' will also be considered in terms of social mobility for mixed-race Māori identity.

\section{Mixed-Race Fragility}

In 1854, the Marriage Act introduced compulsory marriage registration for Pākehā couples. ${ }^{5}$ Māori and interracial couples could choose to register this way or continue marrying under Māori custom. From 1814, Christian missionaries' arrival in New Zealand saw custom influenced by the insistence of monogamy and Christian morals. ${ }^{6}$ Missionaries would often officiate Christian marriages for Māori and mixed couples. Though the missionaries' presence was persuasive, it was not redefining. This is as "Māori marriage took diverse forms and couples regularly entered unions without reference to Christian models or secular marriage law."7 As will be discussed later, it was not until 1910/1911 that it became compulsory for Māori to record marriages on a separate register. This meant that Māori and interracial couples who married before 1910 under the 1854 Act would have been recorded as Pākehā since it did not apply to Māori. ${ }^{8}$ However, any interracial marriage, customary or Pākehā, was considered

\footnotetext{
2 Minelle Mahtani, 'What's in A Name? Exploring the Employment of 'Mixed Race' as an Identification', Ethnicities, Vol. 2, no. 4, 2002, p. 470.

3 ibid, p. 471.

4 Tess Moeke-Maxwell, 'Bi/Multiracial Maori Women's Hybridity in Aotearoa/New Zealand', Discourses: Studies in the Cultural Politics of Education, Vol. 26, no. 4, 2005, p. 506.

${ }^{5}$ Marriage Act 1854, s. 27.

${ }^{6}$ Angela Wanhalla, 'Modernizing' Māori Marriage in New Zealand', Journal of Religious History, Vol. 43, no. 2, June 2019, p. 219.

7 ibid.

${ }^{8}$ Angela Wanhalla has done extensive work collating alternative materials such as church records and intentions to marry which did list race and Wanhalla has crossed referenced these with marriage certificates, see: Angela Wanhalla, 'Modernizing', pp. 217-133.
} 
"fragile" and the children from such unions were representative of this. ${ }^{9}$

Most mixed-race children were recorded as being born from "well behaved European fathers, and high born native mothers" or "parents living as a couple under Māori custom."10 This division matters as the former represented harmony and signalled to the government that such children would be easily assimilated. The latter posed a financial and moral risk. 'An Ordinance for the Support of Destitute Families and Illegitimate Children' was enacted in October 1846 to summon fathers and/or relatives to provide financial help to 'half-caste' children upon abandonment. ${ }^{11}$ The intentions behind this were twofold. Firstly, it was an anticipatory approach where relatives were entrusted to prevent a child from destitution if they were deserted by their father. Secondly, it was to help the government avoid spending money on children "who had relations competent to sustain them." 12 The 1846 Ordinance made very clear that if such a support person was not present in a child's life, they would be supported by the government. The Governor of New Zealand, George Grey, stated that "no greater evil could scarcely be imagined than a race of half-caste children coming within our circle...who, being left without proper support, would have recourse to every species of impropriety."13 The Colonial Secretary, Andrew Sinclair, echoed Grey's sentiments believing that "some provision should be made for them - but he thought that it should be made in education - for it was admitted by all the world, that all half-caste children, unless highly educated, imbibed the vices of both races." 14

Mixed-race children thus became a source of anxiety in early colonial New Zealand. Parliamentarians did not want the children to be brought up by their Māori whanau, but at the same time they were touted by the government as a great colonial 'accomplishment'. The children needed to act the part of their Pākehā heritage with standards to match if, as intended, they were to join the circle of the Pākehā middle class. It was suggested by the NZLC that the 1846 Ordinance should stipulate that 'half-caste' children be entrusted to a Pākehā woman to raise, if their Pākehā parent left them. In the end it was proposed that if a 'half-caste' child was left "to the care of any persons of the native race," such as their Māori mother, then the deserter had to pay "an additional sum towards the education of such children in the English language and Christian religion." 15 This was to encourage "fathers to get European women to take charge

\footnotetext{
${ }^{9}$ Angela Wanhalla, Matters of the Heart, p. 57.

10 ibid.

${ }^{11}$ An Ordinance for the Support of Destitute Families and Illegitimate Children, 26 October 1846, s. 1.

12 'Legislative Council', Nelson Examiner and New Zealand Chronicle, 26 December 1846, p. 3.

13 ibid.

14 'General Legislative Council', Daily Southern Cross, 25 August 1849, p. 4.

15 'Legislative Council', Nelson Examiner and New Zealand Chronicle, 26 December 1846, p. 3.
} 
of these children, by making them pay more when the child was left with the Maori mother."16 There were varying levels of acceptance in colonial society that intersected with gender inequality when one was born from a Māori/Pākehā relationship. In the case of the 1846 Act, such variance manifested itself in an ugly, racist rhetoric.

Contradictory social rules grew from the fear of white fathers abandoning responsibilities and white women going "native" if they had a child with a Māori man. ${ }^{17}$ Worry was exacerbated by the belief that the more Pākehā the upbringing the more civilised the child would be. ${ }^{18}$ An 1852 Taranaki Herald article stated of Pākehā men who marry Māori women that "[Māori wives] can never be [a] friend and companion; [they] may be [a] servant." 19 The same article also stated that most Māori men would not marry white women as "he feels her superiority, and he cannot make a slave of her" as, it is implied, he would a Māori woman. ${ }^{20}$ By 1856 it was reported that only three marriages were witnessed where the husband was a Māori man and the wife was a Pākehā women. ${ }^{21}$ Three years later it was stated that though "Caucasian blood already flows in the veins of two thousand of the native population" this was only because of the children of Māori women to Pākehā men. ${ }^{22}$ Even half a century later, in 1903, it was observed in a literary column for The Press that "very few Maori men marry white women, except Irish women." ${ }^{23}$ However, the latter part of the statement was said to lack "real ground" for accuracy. ${ }^{24}$ Whatever the child's parental mix was, it was the essence of these views that shaped legislation and legal administration of marriage and in turn land.

\section{Divide and Conquer: Mixed-Race vs. Māori}

In 1856 responsible government was established. ${ }^{25}$ That is, ministers were responsible to the House of Representatives and were required to have the confidence of the House. The electoral rules that followed from the 1852 Constitution, however, operated to exclude most Māori from the vote. ${ }^{26}$ Parliament discussed Māori without Māori being represented. In 1856 Governor of New Zealand, Thomas Gore Browne, appointed a board to report on 'Native

\footnotetext{
16 ibid.

${ }^{17}$ Angela Wanhalla, Matters of the Heart, pp. 112-114.

18 ibid.

19 'The Taranaki Herald New Plymouth', Taranaki Herald, 29 September 1852, p. 2.

20 ibid.

${ }^{21}$ Angela Wanhalla, Matters of the Heart, p. 110.

${ }^{22}$ Arthur S. Thomson, The Story of New Zealand: Past and Present-Savage and Civilized, Volume 2 (London: John Murray, 1859), pp. 305-306.

23 'Literary Column. A Journey Through New Zealand', The Press, 4 March 1903, p. 8.

24 ibid.

${ }_{25}$ Atholl Anderson, Judith Binney, Aroha Harris, Tangata Whenua: A History, (Wellington: Bridget Williams Books, 2015), pp. 223-224.

26 ibid.
} 
Affairs' ${ }^{27}$ Among many issues discussed (such as land, liquor, ammunition, the press, and education), were mixed-race children. The report considered mixed-race children an "increasing and interesting class of individuals." 28 Their intermediary position in colonial society was considered useful in accelerating the colonisation process through population. ${ }^{29}$ However, mixed-race children's characteristics were contradictorily said to have no "advantages" or good traits from either their Māori or Pākehā parent. ${ }^{30}$ However, "by proper management" they could avoid behaving unacceptably due to neglect and instead could "be directed in the wellbeing of the Colony." 31 The report introduced a plan for the "proper management" of the children:

They are objects of great solicitude to their native relatives, as well as to their European fathers, who desire to secure them sufficient portions of land for their maintenance, and when such is the case there is every reason for the cooperation of the Government. The [Native Land] Board would therefore recommend, provided the native title is in the first place extinguished, that Crown Grants should be issued in their favor in trust to some public functionary. ${ }^{32}$

The power and wealth of land in Pākehā ideology was considered so very different to the power and wealth of land in Māori ideology. Pākehā wanted land, and the 1856 report exposed the use of mixed-race children to attain it. The implication is that the 1856 report was bargaining on a parent's love of their child to remove land from Māori customary ownership. In doing so, the children were not regarded as capable of managing their own ancestral land.

At the end of the appendix of evidence in the 1856 report it generally concluded that the Māori population was decreasing. ${ }^{33}$ This is the same report that noted 'half-castes' were increasing in population. Damon Salesa states on the Māori/mixed-race differentiation that "indigenous discourses did not make the fetish of race crossing that colonial discourses did... the constitution of 'half-caste' as an operational colonial category, and the targeting of mixed families, had made clear the expanded horizons of colonial rule." ${ }^{34}$ As will be explained later in this chapter, indirectly defining a 'half-caste' as someone who is not Māori was not

\footnotetext{
27 'Report of the State of Native Affairs in New Zealand', Appendices to the Journals of the House of Representatives (AJHR), Session 1, 9 July 1856.

28 ibid., p. 5.

29 'Report of the State of Native Affairs in New Zealand' AJHR, Session 1, 9 July 1856, p. 5.

${ }^{30}$ ibid.

31 ibid.

32 ibid.

33 'Report of the State of Native Affairs in New Zealand' AJHR, Session 1, 9 July 1856, p. 4.

${ }^{34}$ Damon Salesa, Racial Crossings: Race, Intermarriage, and the Victorian British Empire, (New York: Oxford University Press, 2011), p. 214.
} 
something Māori took lying down. There was continuous pushback to this variant of blood quantum division. Popularised in the USA, blood quantum, took on a unique New Zealand meaning. Melissa Derby and Sonja Macfarlane describe blood quantum in the New Zealand historical context as "the archaic notion of defining who is (or who is not) Māori based on a mathematical formula, whereby (we think) we are supposed to divide the number of generations since our tūpuna (ancestors) were 'full-blooded' by the number of marriages with people who are non-Māori in order to determine who is a "real Māori' (or not)." 35 Māori resistance was seen in the resurgence of self-identification in the late twentieth century. However, the superimposition of British racial hierarchy and blood quantum through a divide and conquer method continued.

The 1860 Half-Caste Disability Removal Act had two intended purposes, one primary and one secondary. ${ }^{36}$ Its first purpose was to retroactively legitimise mixed-race children born out of wedlock, this encompassed customary marriages. If the parents married under Pākehā law after the child's birth or within a year of the 1860 Act being passed, then:

Such children shall be deemed to be the lawful issue of such parents and shall be capable of inheriting property, and shall have to all intents and purposes such and the same rights as they would have had if such parents had been legally intermarried before the birth of such children. ${ }^{37}$

The reason this stipulation was of the most importance was because of both Christianity and land. It would only apply to 'half-caste' children and not general "illicit connections." 38 This was a modification of the law of 'illegitimacy', where during the period of first contact interracial relations were "under circumstances which in some degree should modify the judgments pronounced generally." 39 If the parents had "subsequently made all the reparation in their power by marrying" then mixed-race children should not have to carry "all invidious disability." 40 This modification was only to be temporary to dissuade encouragement of 'illegitimate' relationships.

The secondary purpose that was debated was about land and Pākehā morals. Prior to the 1860 Act "a Maori woman possessing any property in land retained those rights so long as she remained only the mistress of a European, but the moment she married she forfeited those

\footnotetext{
${ }^{35}$ Melissa Derby and Sonja Macfarlane, 'How High is your RQ?' Is Te Reo Māori the New Blood Quantum?', Te Kaharoa, Vol. 11, no. 1, 2018, p. 219.

${ }^{36}$ Thomas Forsaith, New Zealand Parliamentary Debates (NZPD), 1858-60, p. 640.

${ }^{37}$ Half-Caste Disability Removal Act 1860 , s. 3.

38 Thomas Forsaith, NZPD, 1858-60, p. 640.

39 ibid.

40 ibid.
} 
rights, because our [settler] laws did not recognize the tenure by which her property was held." 41 Parliamentarian Thomas Forsaith saw this as an incentive "in favour of concubinage." 42 Forsaith believed the "premium" should be removed as then more children born out of wedlock could be made legitimate as their Māori mothers' would not fear they would lose their land. Another parliamentarian, Fredrick Weld, agreed stating that "it was unjust that a Native woman by contracting marriage should lose rights which she would be allowed to retain when living in a state of concubinage." 43 It seems counterintuitive that parliament would debate that it was unfair to take a Māori woman's land away through Pākehā law, given Pākehā preoccupation with Māori land. Nevertheless, Māori women's land would be protected through the 1860 Act, and the customary gifting of land to her child/ren could continue without worry of ownership, regardless of her husband's race. This is because it was stipulated that it "shall not affect the inheritance of any hereditaments which before the passing of this Act may have descended to any person to the exclusion of any child or children legitimatized by this Act." ${ }^{\prime 4}$ The morals of Pākehā marriage, compared to customary marriage, seemed to trump Pākehā interest in Māori land. These morals were to do with settler Christianity and the 'legitimising' of children. However, the promise of securing a Māori woman's land for her, if she married according to Pākehā law, was another example of the attempts to remove Māori customary marriage.

\section{Kemp's Purchase and Mantell's Promise}

The Native Land Acts of 1862 and 1865 not only removed Crown pre-emption to buy Māori Land, it created the Native Land Court. The removal of this pre-emption allowed for the introduction of private sales between settlers and Māori. The creation of the Court saw the facilitation of the transition from Native communal holdings to individual holdings for the private sales. Māori could write to the Court stating they had a claim on land and wanted a land title issued following investigation into ownership. No matter the number of acres in any block, a maximum of ten owners was allowed. A wave of Māori were now involved in the Pākehā economic system with freehold title where an individual could sell, rent and do anything at their whim for their own profit with no need for consultation with their iwi. In 1860, when the 1862 and 1865 Acts were in the reading stages, Lieutenant-Colonel Andrew Russell saw the Court as a way to relieve Pākehā as "it was unpleasant to be living, as we were at present, in a state of sufferance; and, if for no other consideration, he would support the Bill as it would

\footnotetext{
41 ibid.

42 ibid.

${ }^{43}$ Fredrick Weld, NZPD, 1858-60, p. 640.

${ }^{44}$ Half-Caste Disability Removal Act 1860, s. 3.
} 
enable us, he thought, in time to become masters of the country." 45 Colonel William Henry Kenny concurred with Russell stating that "he should vote for its adoption, because it would put the Europeans in possession of native lands - in fact, make us masters of the country, which was the object desired." 46 The "suffering' that Russell and Kenny believed Pākehā, such as themselves, were enduring was something that an area purchased 12 years earlier, in the South Island, in excess of 20,000,000 acres, did not alleviate.

Kemp's Purchase, also known as the Ngāi Tahu purchase, occurred in 1848 where more than 20,000,000 acres was bought from Ngāi Tahu for $£ 2,000 .{ }^{47}$ Henry Kemp oversaw the acquisition, and was told to extinguish native title, reserve some land for Māori, and most importantly, purchase it. ${ }^{48}$ However, the purchase strayed from the instructions given to Kemp as transactions took place without reserves for Māori being confirmed. Walter Mantell was appointed by the government to determine the reserves for Māori which Kemp failed to do. ${ }^{49}$ Mantell stated in 1888, 40 years after Kemp's purchase that:

... I believed at the time, and reported to that effect, that the reserves were sufficient for the present and future wants of the Natives, but now I believe them to be insufficient... I think now the reserves ought to have been larger. I have come to this conclusion because the Native sources of food are lessened... At that time my estimate was Colonel McCleverty's, whom I consulted. The idea was to allow enough to furnish bare subsistence by their own labour.... I have not said that I thought the reserves sufficient to satisfy the honour of the Crown, but, according to Colonel McCleverty's opinion, sufficient to live upon.... My rule, in calculating what quantity of land I would give the Natives, was that I allowed ten acres to each man, woman, and child.... In making the allowance I tried to allow as little as the Natives would agree to take... I was instructed verbally by Lieut.-Governor Eyre to make certain promises to the Natives of what the Government intended to do for them in addition to paying for the land. I made this representation, and found it had great weight in inducing the Natives to come under the deed, but these promises have not yet been fulfilled. ${ }^{50}$

\footnotetext{
${ }^{45}$ Lieutenant-Colonel Andrew Russell, NZPD, 1861-63, p. 716.

${ }^{46}$ Colonel William Henry Kenny, NZPD, 1861-63, p. 716.

${ }^{47}$ Report on Middle Island Native Land Question', AJHR, Session 1, G-1, 1 January 1888, p. 3.

48 ibid.

49 ibid.

50 'Report on Middle Island Native Land Question', AJHR, Session 1, G-1, 1 January 1888.
} 
The "certain promises" Mantell mentions are were aimed directly at interracial couples, with Mantell saying in 1869:

So when I was sent in August [1848] to persuade or compel those natives who had not joined in Kemp's deed to acknowledge that their land was sold to the Crown, and with the rest to permit the survey of Reserves within the Block, I was instructed to promise these people, that when the land belonged to the Crown provision in land under Crown Title would be made for their wives and children. To have included this provision within the Native Reserves would have, it was held, subjected the Natives therein to undue domination on the part of the Whites and half-castes of their families. ${ }^{51}$

The Stewart Island Grants Act 1873 was enacted due to Stewart Island/Rakiura land being ceded to the Crown by Māori under the provision that some areas of land "should be reserved for and divided amongst the half-caste residents." ${ }^{52}$ The Land Claims Commissioner, Harry Atkinson, wrote to Alexander Mackay, the Commissioner for Native Reserves (Nelson), in 1876 about Mantell's promise. Atkinson stated, “if you will make out a list of all those persons of the half-caste race for whom you consider it is desirable that provision should be made - as in the case of the Stewart Island purchase - I shall endeavour to have an Act passed to authorize the issue of grants to them." 53 The Middle Island Half Caste (Crown) Grants Acts of $1877,1883,1885$, and 1887 were thus a consequence of Mantell's promise. ${ }^{54}$

\section{'Half-Castes' and 'So-Called Half-Castes'}

Ngāi Tahu parliamentarian, Hori Kerei Taiaroa, requested that all the information be distributed to the House of Representatives concerning reserving sections of land for 'halfcastes' of Ngāi Tahu. ${ }^{55}$ A list was compiled of those who were considered 'half-castes' and "only those persons who come within the category." 56 Essentially, one would be ineligible for a grant unless their parents were 'full' Māori and 'full' Pākehā. It was stated that in order to fulfil Mantell's promise, women would receive 8 acres of land, and men 10, which equated to roughly 1,676 acres overall. ${ }^{57}$ In 1851 , Mantell stated that he made the reserves small as it

\footnotetext{
51 'Evidence of Walter Mantell before the Public Petitions Committee', 20 July 1869, Land Claims of South Island Half-Castes, MA 13/20 12[e], Part 5, Archives New Zealand, Wellington in Angela Wanhalla, In/Visible Sight, (Wellington: Bridget Williams Books, 2009), p. 96.

52 Stewart Island Grants Act 1873, preamble.

53 'Half Caste Claims in the South and Stewart Island', AJHR, Session 1, G-9, 12 July 1876, p. 11.

${ }^{54}$ Middle Island Half-Caste Crown Grants Act 1877; Middle Island Half-Caste Grants Act 1883; Middle Island Half-Caste Grants Act 1885; Middle Island Half-Caste Crown Grants Acts 1877.

55 'Half Caste Claims in the South and Stewart Island', AJHR, Session 1, G-9, 12 July 1876, p. 1.

56 ibid.

57 ibid.
} 
"would not enable the Natives in the capacity of large landed proprietors to continue to live in their old barbarism on the rents of an uselessly extensive domain." 58

In determining the principles of distribution of land there were two options. First, "whether it was the intention of the Government of the day to make provision for the whole of the half-caste population who were resident within the boundaries of the blocks severally purchased from the Ngaitahu in consideration of their descent on the maternal side from the original proprietors of the soil." ${ }^{59}$ Second, "whether it was merely intended to award land to those who were otherwise unprovided." 60 Though seemingly contradictory to the narrative of a tunnel-vision-land-hungry government, the option taken was the first. The government did not want to go with the second option as "it will appear that those who have obtained land through the forethought of their parents are to be treated with less consideration than those who have descended from the thriftless and improvident." ${ }^{61}$ This choice appears to be a moral one overriding land interest. The government rewarded those who had parents who already had land, without considering the circumstances of those who did not.

There were very strict qualifications to be entitled to a grant. A grantee could not be descended from someone deemed a 'half-caste.' A grantee could not be considered a 'threequarter-caste.' The obsession with precision was shown where Susan Lowry, a 'half-caste' mother, had three daughters who were "disqualified" from receiving a grant for being "threequarter-caste', only Susan's eldest daughter would receive the share that Susan was entitled to by succession. ${ }^{62}$ Mackay believed that it was imperative that the percentage should be strictly 'half' in order to qualify. ${ }^{63}$ This was because any looser interpretation of caste "would open the door to a large number of claimants" and would thus require the government to issue more grants. ${ }^{64}$ With this knowledge, the 1877 'Middle Island Half-Caste Act' passed.

In 1882, Taiaroa requested that the number of claims made under the 1877 Act come before the House of Representatives. The information included the names, the location of the land they were granted, and how many claims were left. ${ }^{65}$ Taiaroa did this as he had heard some 'half-castes' had not received their grants or had their land size detailed. The 'Middle Island Half-Caste Act' 1883 included the names omitted from the 1877 Act and made sure that the land granted was of a high enough standard for self-sufficiency as previous claimants were

\footnotetext{
58 'Native-Land Claims Commission', AJHR, Session 1, G-5, 1 January 1921, p. 33.

59 'Half Caste Claims in the South and Stewart Island', AJHR, Session 1, G-9, 12 July 1876, p. 2.

${ }^{60}$ ibid.

61 ibid.

62 'Half Caste Claims in the South and Stewart Island', AJHR, Session 1, G-9, 12 July 1876, p. 4.

63 'Half Caste Claims in the South and Stewart Island', AJHR, Session 1, G-9, 12 July 1876, pp. 7, 16.

64 ibid.

${ }^{65}$ Hori Kerei Taiaroa, NZPD, 1882, Vol. 43, p. 566.
} 
given land of "inferior quality not sufficient for their support." Caste Act' included names that were not in the earlier Acts and was considered a "technical" Act as it was for rectifying omissions, while the 1885 Special Powers and Contracts Act covered the practical aspect of granting land. ${ }^{67}$ Finally, The 'Middle Island Half-Caste Act', 1888 included those omitted from previous Acts. ${ }^{68}$ In 1890, the grants were still in the process of being actioned showing the Crown's reticence in fulfilling promises its representatives made to acquire Māori land.

\section{Traditions and Consolidations}

In 1888, the Supreme Court heard a case, Rira Peti v Ngaraihi Te Paku. ${ }^{69}$ Chief Justice Prendergast's decision effectively withdrew any legal recognition from customary marriage. The case involved Ngaraihi te Paku who contested that Rira Peti should not be recognised as both the executor and the receiver of the property and legacy of her husband, Pehimana te Paku. ${ }^{70}$ It was argued that the deceased was unduly influenced by Peti and Peti's husband, Tukino Pauro. This case had to determine whether Pauro, who was named as the attester of the deceased's will, was Peti's legal husband. If Pauro was Peti's legal husband, this made the deceased's bequeathment to Peti void under section 15 of the Wills Act 1837 (UK) where the spouse of a beneficiary could not legally be a witness. ${ }^{71}$ Prendergast stated that "unless there is some other law on the subject, marriage between persons of the native race is governed by the common law of England as modified by the Marriage Ordinance of $1842 . " 72$ Prendergast conveniently ignored the recent history of the country in this decision as his "proposition that tribal marriages had been subject to the common law since 1840 " was simply not true. ${ }^{73}$ The 1854 Marriage Ordinance, mentioned at the beginning of this chapter, explicitly stipulated that Māori did not come under the Act. Māori prior to 1888 were consistently exempted from laws relating to Pākehā when Māori custom was already practiced. The Native Land Court Act 1894 saw that customary marriages could be recognised as the Court would have jurisdiction if succession of Māori land or property to a spouse was questioned. The term "successor" in the 1894 Act was defined as "the person who, on the death of any Native, is, according to Native custom, or, if there be no Native custom applicable to any particular case, then according to the

\footnotetext{
${ }^{66}$ Middle Island Half-Caste Grants Act 1883, preamble.

${ }^{67}$ John Ballance, NZPD, 1885, Vol. 52, p. 578.

68 'Middle Island Half-Caste Grants', $A J H R$, Session 1, G-8, 23 July 1890, p. 1.

${ }^{69}$ Rira Peti v Ngaraihi Te Paku (1888) 7 New Zealand Law Reports (NZLR), pp. 235-241.

70 ibid.

71 ibid.

72 ibid.

${ }^{73}$ Grant Morris, Prendergast: Legal Villain? (Wellington: Victoria University Press, 2014), p.119.
} 
law of New Zealand, entitled to the interest of such Native in any land or personal property." 74

The idea of Māori having a collective identity was focused on in face of continuous and irreparable loss of land - this focus included the "nexus between land and people."75 To capitalise on this connection, the 1912 Native Land Amendment Act no longer categorically defined descent by blood. It allowed for the governor, following a recommendation from the Native Land Court, to assert that anyone under the term 'native' could be declared as a Pākehā. ${ }^{76}$ Member of Parliament, William Herries stated that "they had always advocated the freeing of the educated Natives from the shackles of the Native-land laws that kept the down and prevented them being placed on the same footing as the European." 77 Mixed-race Māori Member of Parliament, Peter Buck (later Te Rangi Hiroa), wondered if Māori were ready be on equal footing with Pākehā stating:

Younger members of the Maori race, who had had the advantage of being born in more civilized times and of having the advantages that the New Zealand educational system gave them of acquiring some education and of mixing with Europeans, it might seem almost a disgrace to be held in by restrictions; but, personally, he would sooner that those restrictions existed in his own case than that a number of his own people should suffer because there was no protection afforded to them. $^{78}$

In a compromise between the two parliamentarians, to be declared Pākehā would only mean you would be considered Pākehā in terms of the law. But, if you were declared to be Pākehā you would have met requirements that suggested you were of a mixed-race background. This is seen in the requirements for recommendation where "the Native applying is acquainted with the English language, and is possessed of educational qualifications equal to the Fourth Standard as prescribed by the Education Act, 1908."79 It also stipulated that if upon application they have "Native freehold land...or sufficient European land... or that he is, in the opinion of the Court, able to earn an adequate maintenance by reason of some special profession, trade, or calling; or that he has any other income which in the opinion of the Court is sufficient for his adequate maintenance." 80

\footnotetext{
${ }^{74}$ Native Land Court Act 1894, s.2.

${ }^{75}$ Richard Hill, State Authority, Indigenous Autonomy: Crown-Maori Relations in New Zealand/Aotearoa 19001950, (Wellington: Victoria University Press, 2004), p. 98.

${ }^{76}$ Native Land Amendment Act 1912, s. 17.

77 William Herries, NZPD, 1911, Vol. 156, pp. 966-967.

${ }^{78}$ Peter Buck, NZPD, 1911, Vol. 156, pp. 966-967.

${ }^{79}$ Native Land Amendment Act 1912, s. 17(4)(a).

80 ibid., s. 17(4)(b).
} 


\section{The Native Land Act of 1909}

The Native Land Act of 1909 stated that Māori couples and Māori/Pākehā interracial couples had to register their marriages on a register separate to Pākehā couples. ${ }^{81}$ It did this by repealing the previous exception in the 1854 Marriage Act. The 1909 Act no longer recognised Māori customary adoption as legal due to the removal of any form of registration for it through the Native Land Court. Māori couples and Māori/Pākehā interracial couples were enticed to marry in accordance with the 1854 Marriage Act as "no adoption in accordance with Native [marriage and whāngai] custom, whether made before or after the commencement of this Act, shall be of any force or effect, whether in respect of intestate succession to Native land or otherwise." ${ }^{82}$ As a replacement, the Act introduced a protection "by will.",83

In the parliamentary debates concerning intestacies, Taranaki parliamentarian Thomas Kelly, proclaimed that "the law already said that a Maori had all the rights of a British subject. Well, one of the rights of a British subject was the inheritance of property that belonged to a relative who died intestate. Why did this not apply to the Maori people?"84 Adoptive parents now needed to have a formal will set up for their children to be beneficiaries. This new approach was "based on the adoption of European children before the Magistrates." ${ }^{85}$ However, for Māori, it would be before the Native Land Court. A "full” Pākehā child could not be adopted by Māori, but Māori could adopt Pākehā children "so defined with Maori blood in his veins." 86 In the case of the latter, the child would attain the same succession rights for property as a Pākehā child, but this would be under the Māori register. Notably, Pākehā could not be named a beneficiary in a Māori registered will, unless they were the husband or wife or in a similarly close relationship. Thus, interracial Māori/Pākehā marriages would always be through the Native Land Court and not the Pākehā register.

Regarding intestacies, if the land was considered "Native freehold" it would be passed on to the children of the deceased as per Māori custom. However, if the children of the deceased were born to parents who did not have a Native Land Court registered marriage the children would be considered illegitimate and would not be guaranteed beneficiaries if either of the parents had 'legitimate' children. This was due to "a laudable desire to encourage Natives to get married according to New Zealand law, the provision of the Marriage Act which recognised

\footnotetext{
${ }^{81}$ Native Land Act 1909, s. 190.

82 ibid., s. 161.

${ }^{83}$ Native Land Act 1909; 'The Native Land Act. Review of the Alterations.' Poverty Bay Herald, 9 February 1910, p. 2.

84 Thomas Kelly, NZPD, 1910, Vol. 152, p. 254.

85 'The Native Land Act. Review of the Alterations.' Poverty Bay Herald, 9 February 1910, p. 2.

86 Native Land Act 1909, s.164; 'The Native Land Act. Review of the Alterations.' Poverty Bay Herald, 9 February 1910, p. 2.
} 
Maori customary marriages, has been repealed and a ready means of marrying before an officiating clergy-man prescribed." 87 Without registration through the marriage register, children were at a risk of losing land regardless of customary acknowledgement of marriage.

Arguably the most staggering amendment in the Act was the removal of any provision for children considered 'three-quarters-European-one-quarter-Māori' or those "intermediates in blood between a half-caste and a European." 88 If the parents of such children were not officially registered as married, the child would not have presumed succession of Māori freehold land as per custom in the event of intestacies. The child would be considered Pākehā and come under general law. This is significant because freehold Māori land was "protected against execution and bankruptcy" unlike Pākehā land which could be used to cover debt liabilities left by the deceased that the successor became responsible for. ${ }^{89}$ This provision for Māori was in line with Richard Seddon's beliefs in 1900 concerning Māori land administration where the goal of the government was to "prevent Maoris from becoming landless [and would] lead to subdivision...put a stop to this communal life which is so disastrous to their wellbeing." 90 This meant those who considered themselves Māori, but were not by definition of the 1909 Act considered 'Native' could mortgage their land as it would be deemed Pākehā because "the exemption attaches to the person and not to the land, so that land exempt in the hands of a Native may not be so in the hands of his successor being a European."91

\section{Equality or Equity?}

In 1910, Āpirana Ngata gave a speech in parliament about intermarriage, land and the consequences that the past 50 years would have for the next 50 years. Ngata quotes the speech William Herries made in parliament regarding the Māori Land Laws Bill 1903 which stated: "I look forward to the next hundred years or so to the time when we shall have no Maoris at all, but a white race with a dash of the finest coloured race in the world...I believe that is the ultimate solution of the Maori question - an intermingling of the races, where you have the best qualities of both, combined and mixed together, so as to make a new Anglo-Saxon-Maori race in these Islands." 92 Ngata expressed that both he and the Young Maori Party agreed, stating their aim was not "to preserve the Maori race as a separate and distinct race...the aim and effort of the party is to secure that fusion is brought about on the highest possible plane." 93 Though

\footnotetext{
87 'The Native Land Act. Review of the Alterations.' Poverty Bay Herald, 9 February 1910, p. 2.

${ }^{88}$ Native Land Act 1909, s.2.

89 Native Land Act 1909, s.423; 'The Native Land Act. Review of the Alterations.' Poverty Bay Herald, 9 February 1910, p. 2.

${ }^{90}$ Richard Seddon, NZPD, 1900, Vol. 115, p. 172.

91 'The Native Land Act. Review of the Alterations.' Poverty Bay Herald, 9 February 1910, p. 2.

92 William Herries, NZPD, 1903, Vol. 137, p. 538 in Āpirana Ngata, NZPD, 1910, Vol. 150, pp. 577-582.

93 Āpirana Ngata, NZPD, 1910, Vol. 150, pp. 577-582.
} 
Ngata's stance on this would change in later years, (which will be shown in greater detail in chapter four) Ngata was making a clear distinction between Herries' point of view and the Young Maori Party's. Herries was happy about interracial children leading to the dissolution of Māori, the latter had resigned themselves to it.

Despite sharing the goal to treat both Māori and Pākehā equally, Ngata wanted to know how this would be attained by removing provisions set aside for Māori which would "throw the Maori absolutely on his own resources, and at once, and to let him fend for himself." 94 Ngata went on to mention that in the past, land provisions for Māori were positively thought of by the likes of William Massey in 1897 who stated it was imperative to leave Māori "in nearly as possible the same position as Europeans." 95 The main point of difference in the early twentieth century Māori question was that Ngata saw that the provisions lessened the gap of difference in order for Māori to be equal while Herries and the opposition saw the removal of provisions for Māori would mean they were being treated equally.

Ngata, rather boldly, claimed in the 1910 speech that "there is not in the legislation of New Zealand any legislation which differentiates between Maori and pakeha as such." ${ }^{96}$ Ngata genuinely understood the definition of differentiation to be when "the Maori is not penalized as a Maori." ${ }^{97}$ Ngata believed the provisions made were equity measures to bring Māori to the same place as Pākehā and to protect Māori. Ngata argued that laws for Māori had historically, and should continue to, come back to the idea that "the native mind was not ripe to receive [equal laws to Pākehā]." 98 The provision in the aforementioned 1909 Act which protected Māori land from “execution or bankruptcy” was brought up in Ngata's speech. On this issue Ngata argued:

You do not have to go very far to find that there is differentiation as between Maori and pakeha, not because one is a Maori and the other a pakeha, but because of the character of one, his business ability and position, does not give to the financial institutions that confidence which the character, ability, and position of the average European does give. ${ }^{99}$

\footnotetext{
94 ibid.

${ }^{95}$ William Massey, NZPD, 1897, Vol. 99, pp. 573-575 as quoted by Āpirana Ngata, NZPD, 1910, Vol. 150, pp. 577-582.

${ }^{96}$ Āpirana Ngata, NZPD, 1910, Vol. 150, pp. 577-582.

97 ibid.

98 ibid.

99 ibid.
} 
The fundamental difference Ngata makes between Māori and Pākehā is that of character, not of colour. However, his distinction based on character echoes William Herries ideas about the children of inter-racial unions becoming the future of Māori as "a white race with a dash of the finest coloured race in the world." 100 The 1909 Act defining anyone less than 'half' Māori as Pākehā was a direct reference to the notion of this thesis that mixed-race children were afforded privileges that other Māori were not.

The early twentieth century saw a shift from Pākehā enforced land removals to Māori removing themselves from their remaining land and "customary patterns of living." 101 This was due to increased poverty and reliance on welfare as employment opportunities in industries (such as timber) near their land dwindled. During the 1930s, seasonal work saw Māori migrate to work in agriculture (shearing, general duties) and market gardens. ${ }^{102}$ In 1929, Māori owned land was taken under the Māori land development scheme. ${ }^{103}$ This was introduced so Māori could be enabled to use their lands efficiently. The owners of land could not injuriously get in the way of the government development that took place which forced the move away from communal to individual use. ${ }^{104}$ This included Māori being unable to sell or lease their own land. By the mid-twentieth century, there had been a noticeable change in government ideas regarding Māori moving from their rural homes to the city to counter the severe poverty and general lack of opportunities. The former "entrenched belief" was that "Māori were and would always be a rural people, separated from Pākehā." ${ }^{105}$ Melissa Williams states that in the early twentieth century "reconfiguring the nation's colonial boundaries was not seriously on the state's agenda." 106 What was on the governments agenda by 1967 was the Maori Affairs Amendment Act, which converted any Māori land with fewer than four owners to 'general', not Māori land. This has been described as the "last land grab", which resulted in major public opposition. $^{107}$

The Maori Purposes Act 1951 decided that "every marriage to which a Maori is a party

\footnotetext{
${ }^{100}$ William Herries, NZPD, 1903, Vol. 127, pp. 537-538 quoted by Āpirana Ngata, NZPD, 1910, Vol. 150, pp. 577-582.

${ }^{101}$ Melissa Matutina Williams, Panguru and the City: Kāinga Tahi, Kāinga Rua: An Urban Migration History, (Wellington: Bridget Williams Books, 2016), p. 41.

102 ibid., p. 43.

103 Tai Tokerau District Maori Land Development Scheme Register, c. 1961, Series 24179, Box 5, Record R23419177, Archives New Zealand, Auckland.

104 ibid.

105 Melissa Matutina Williams, pp. 69-70.

106 ibid.

107 Aroha Harris, Hīkoi: Forty Years of Māori Protest, (Wellington: Huia Publishers, 2004), p. 24; Ranginui Walker, Ka Whawhai Tonu Matou - Struggle Without End, (Auckland: Penguin, 1990), pp.139, 207; Richard Hill, Maori and the State: Crown Relations in New Zealand/Aotearoa 1950-2000, (Wellington: Victoria University Press, 2009), p. 158.
} 
shall be celebrated in the same manner, and its validity shall be determined by the same law, as if each of the parties was a European." ${ }^{108}$ This created only one valid marriage law and ended the legal recognition of Māori customary marriage. Angela Wanhalla argues by that through this "amalgamation was finally achieved." 109 This argument differs to those made by Māori and Pākehā Members of Parliament at the time. Ernest Corbett was Minister of Māori Affairs for the National Party from 1949-1957, during the Holland, then Holyoake premierships. Corbett believed that the Act was merely a formality to ease succession in relation to land stating:

I want to make it quite clear that the clause does not in any way affect these customary unions that have already taken place or that will have taken place prior to 1 April 1952. Those who know the Maori people know that these customary unions have been as binding as, if not more binding than, many European marriages. However there has been trouble from customary marriages in that the difficulties of succession in relation to Maori lands are multiplied. It is felt that in 1951 the time has arrived when the Maori marriage laws should be the same as those apply to Europeans in New Zealand. ${ }^{110}$

Though we can see now that through this Act marriage law amalgamation was complete, it also makes sense that they would consolidate two systems for the ease of probate dealings. It is important to consider why there was a need to make the system easier; simply, interracial relationships continued.

Eruera Tirikatene, the Southern Māori District MP for the Labour Party attended the Māori Purposes committee where the 1951 Bill was considered prior to its third reading. Tirikatene believed "the Maori people, as from 1 April 1952, must conform to the laws of consanguinity that apply to Europeans. It is well that that should be so, because it will facilitate matters relating to inheritance and social-security benefits."111 Tirikatene and Corbett's statements are quite stark, though both referred to making the system easier for Māori in terms of benefits and succession. Tirikatene approved of this law due to the Pākehā pre-occupation with blood quantum in terms of intestate succession and being a beneficiary of an estate as laid out by consanguinity. This point of view places the blame on Pākehā for the law regarding marriage becoming so confusing.

\footnotetext{
${ }_{108}$ Maori Purposes Act 1951, s. 8(1).

${ }^{109}$ Angela Wanhalla, Matters of the Heart, p. 51.

${ }^{110}$ Ernest Corbett, NZPD, 1951, Vol. 296, p. 1358.

${ }^{111}$ Eruera Tirikatene, NZPD, 1951, Vol. 296, p. 1359
} 
It was Pākehā who superimposed the obsession with blood into New Zealand law and everyday life, not Māori. Angela Wanhalla, among other scholars, note that after considering historians' and demographers' observations of the time, "these decades were characterised by 'high levels of intermarriage', accelerated by Māori urbanisation."' 112 By the early $21^{\text {st }}$ century, such relationships were very common indeed. Statistics New Zealand researchers Paul Callister, Robert Didham and Deborah Potter found that by 2001, "a significant number of Maori living in couples are recording both European and Maori ethnicity."113 What the research notes is the steady acceleration of intermarriage from the 1950s led to these "complex interactions." 114 The complexity is attributed to the "greater likelihood of younger people to report multiple ethnicities." 115 The available pool of people in New Zealand in 2001 was also noted to contribute to Māori (well qualified women in particular) "to look beyond" and embrace the differences in their choice of partners. ${ }^{116}$

\section{Whakamā}

A 2019 opinion piece on New Zealand online commentary site, The Spinoff, made a poignant remark regarding questions of whether someone is Māori 'enough' which inadvertently called back to the consequences of urbanisation. ${ }^{117}$ Labour Member of Parliament, Willie Jackson, questioned National Member of Parliament, Paula Bennett, on the validity of her Māori identity. Regardless of political allegiances, deciding that someone has less of a claim to being Māori because they do not know te reo or are less intimately connected to their whakapapa is problematic. This political episode is a reminder of the conversations around Māori urbanisation and Pākehā fears that Māori would not adjust to Pākehā centred landscapes and as a result would experience social and emotional dislocation. ${ }^{118}$ The fears eventuated, just not as anticipated. Regarding the Bennett incident The Spinoff stated:

There was no consideration that there might be a group of people in our community struggling in first year language classes; squinting at whakapapa put on Facebook groups they joined in the hope of finding

\footnotetext{
112 Angela Wanhalla, Matters of the Heart, p. 146,

113 Paul Callister, Robert Didham and Deborah Potter, 'Ethnic Intermarriage in New Zealand', Working Paper, Statistics New Zealand, 2005, p. 29.

114 Paul Callister, Robert Didham and Deborah Potter, p. 35.

115 ibid., p. 31.

116 ibid. p. 35.

117 Graham Cameron, 'The Cruelty Behind Willie Jackson's Attack on Paula Bennett's Māori Identity', The Spinoff, 6 May 2019; accessed 10 May 2019.

118 Angela Wanhalla, Matters of the Heart, p. 143.
} 
out more; being bullied at school for being brown; and being rejected

by Māori who mock them for being too white. ${ }^{119}$

In another Spinoff article from 2019 one person states "even if I did want to explore my Māori whakapapa, I wouldn't know where to start." 120 To discover who you are is a big decision. To know your whakapapa is a gift that many do not have yet it is a hard gift to navigate because of the emotional weight of a shared mixed-race experience. Joan Metge usefully encapsulates the essence of this emotion through the concept of Whakamā: "not only shyness and shame but also feelings of inferiority, inadequacy, self-doubt and (but not necessarily) guilt. Its root meaning could be rendered as 'conscious of being at a disadvantage."'121 The idea of not knowing or feeling 'enough' is what I have found to be the underlying theme of all of my interviewees.

Matthew explained to me that being mixed-race had always been difficult for him because when he was with his white cousins, he and his brother would be looked at as "the naughty Māori boys." However, when he went to his marae in Wairoa to spend time with his Māori cousins “we were the goody good white boys, so we couldn't win, and we didn't know our own identity, we were torn. Where do we fit? What are we doing? Who and how are we supposed to act?"122 Matthew told the story of his experience shopping in a boat store in Plimmerton trying to buy a new bung for his boat, "the guy came over and was like 'oh you're in the wrong place, those ones are too big." Despite Matthew knowing exactly what he was looking for, the storeman continued "yeah, the ones for waka ama are over here." 123 Matthew, being Samoan and Māori on his father's side and white on his mother's side understood that the man assumed, because of his looks, that he would be involved in waka ama, traditionally a Polynesian sport.

Rhianna stated that she dealt with situations in her childhood where internally she did not feel Māori enough, but externally - and through colourism - she straddled the border between her Pākehā upbringing and her Māori looks. Rhianna stated, "the first school I went to was primarily a white school, I just remember saying I wish I wasn't brown and I wanted to be white because everyone at school was white and I remember saying that to my mum and my mum being horrified that I would say that, obviously at the time I didn't know." ${ }^{24}$ Rhianna

\footnotetext{
119 Graham Cameron, 'The Cruelty Behind Willie Jackson's Attack on Paula Bennett's Māori Identity', The Spinoff, 6 May 2019; accessed 10 May 2019.

${ }^{120}$ Leonie Hayden, 'How to Tell If You're Māori', The Spinoff, 4 January 2019; accessed 10 May 2019.

${ }^{121}$ Joan Metge, Rautahi: The Maori of New Zealand, (London: Psychology Press, 2004), p. 65.

122 Matthew Lambert interview conducted by Kiriana Haze, 22 May 2019, Upper Hutt, New Zealand.

123 ibid.

${ }^{124}$ Rhianna Morar interview conducted by Kiriana Haze, 1 May 2019, Wellington, New Zealand.
} 
further explained that it was not until she started university that she really started learning, exploring and identifying as Māori. Rhianna found Nga Rangahautira, the VUW Māori Law Students' Association and Ngāi Tauira, VUW's Māori Students' Association. However, she did not attend the orientation programmes aimed at first year university students until she was in her third year at VUW. "They were like: 'Why are you [here]? Why haven't I seen you before?' And it was like 'oh because I didn't actually know this was a thing."'125

Vanessa has a contrasting narrative to Matthew and Rhianna stating that "I haven't had any [negative experiences] but that's because I can walk on that very fine line where I can switch into Pākehā or Māori and that's just purely on how I look." ${ }^{126}$ Moeke-Maxwell has considered this hybridity and the link to colourism stating, "corporeality influences the social constriction of Māori identity." 127 Maxwell also touches on the nature of colonisation where "assimilated individuals are perceived to be privileged with Pākehā beliefs, values, practices and norms and are aligned with whiteness/racial superiority and privilege." 128 This, however, is too simplistic. Mixed-race people struggle with the notion of straddling both worlds, but the mentioned privilege is true. There is no 'perceiving'; pale, 'light-skinned' mixed-race people are privileged in acting or looking 'more' assimilated, however much of a paradox that may be. Vanessa continued to explain that the boys she was on her theatre tour with in 2018 had "really bad racist experiences, because one is a really big Samoan boy the other is a big Māori boy with tā moko and everything like that, loveliest boys, and I couldn't relate to [their experiences with racism] because I will probably never have that experience." ${ }^{29}$ The different lived experiences on the colour spectrum between Vanessa and the boys she worked with show how experience is informed by where one places themselves on the scale of brownness. This placement may shift throughout one's life.

Maddison expressed similar sentiments in being mixed-race Māori where she understood that she experienced hybridity due to corporeality and understood her privilege in doing this, but this came with feeling fraudulent. Maddison stated, "there are some things to do with Māori that I'm not as entitled, well not entitled, but I'm not worthy of them, as those that know a lot about their Māori history and everything in Māoridom and te reo and that sort of thing." 130 On the ability of having a fluid racial identity Maddison believed that her selfidentifying as mixed-race Māori has always been static internally, the fluidity was only present externally and was more to do with the influence of those around her, stating;

\footnotetext{
125 ibid.

${ }^{126}$ Vanessa Immink interview conducted by Kiriana Haze, 12 April 2019, Wellington, New Zealand.

127 Tess Moeke-Maxwell, 'Bi/Multiracial Māori Women's Hybridity in Aotearoa/New Zealand', p. 498.

128 ibid., p. 502.

129 Vanessa Immink interview conducted by Kiriana Haze, 12 April 2019, Wellington, New Zealand.

${ }^{130}$ Maddison Baker interview conducted by Kiriana Haze, 14 March 2019, Wellington, New Zealand.
} 
You struggle sometimes to be yourself when you wanna' be. But, then you're thinking about what other people think, and I know you shouldn't be thinking about what other people think of you, but you just do. You kind of want the best outcome and in my mind, sometimes, the best outcome is not being Māori which sounds sad, but, yeah. ${ }^{131}$

\section{Conclusion}

This chapter has shown that for mixed-race Māori, the effects of legislation and legal administration are real and immediate. Regardless, Māori continued and continue to have some customary practices. Different pieces of law told mixed-race Māori what they were, but this does not mean Māori took them as fact. The actual influence of the law was as vast and as various as the people the law was made for. Partial acceptance, unconscious acceptance, complete acceptance or complete denial are all valid responses to such laws. How it is interpreted and acted upon privately versus publicly, officially versus at home, all contribute to choosing one identity or the other, but having very little legal freedom to be both. This chapter considered the limits of legislative assertions as well as the enabling and reaffirming potential in terms of identity. Eric Schwimmer argued in 1990 that "Maori hapū is far from defunct today even though it has shed many functions...we have shown that it may periodically recover its identity as a descent group when its members see the need for it and that it may then restructure itself." 132 The removal of land and marriage custom through legislation and legal administration c.1850-1950 in relation to mixed-race Māori is complex in its intersections and consequences. What happened in the past matters now. Mixed-race children being made "intelligible in ways that maintain racial hierarchy", historically, has resulted in a difficulty to articulate personal identity today. ${ }^{133}$

\footnotetext{
131 ibid.

${ }^{132}$ Eric Schwimmer, 'The Māori Hapū: A Generative Model', Journal of Polynesian Society, Vol. 99, no. 3, 1990, p. 313.

${ }^{133}$ Minelle Mahtani, p. 471.
} 


\section{Chapter Three: Native Schools}

There can be a continuity of identity despite the fact that its composition may have been irrevocably modified, for example, in the case of Māori, by Christianity, literacy and language loss...It is possible that this new identity may be based upon the very process and experience that saw the demise of the old identity...

- Hana O’Regan. ${ }^{1}$

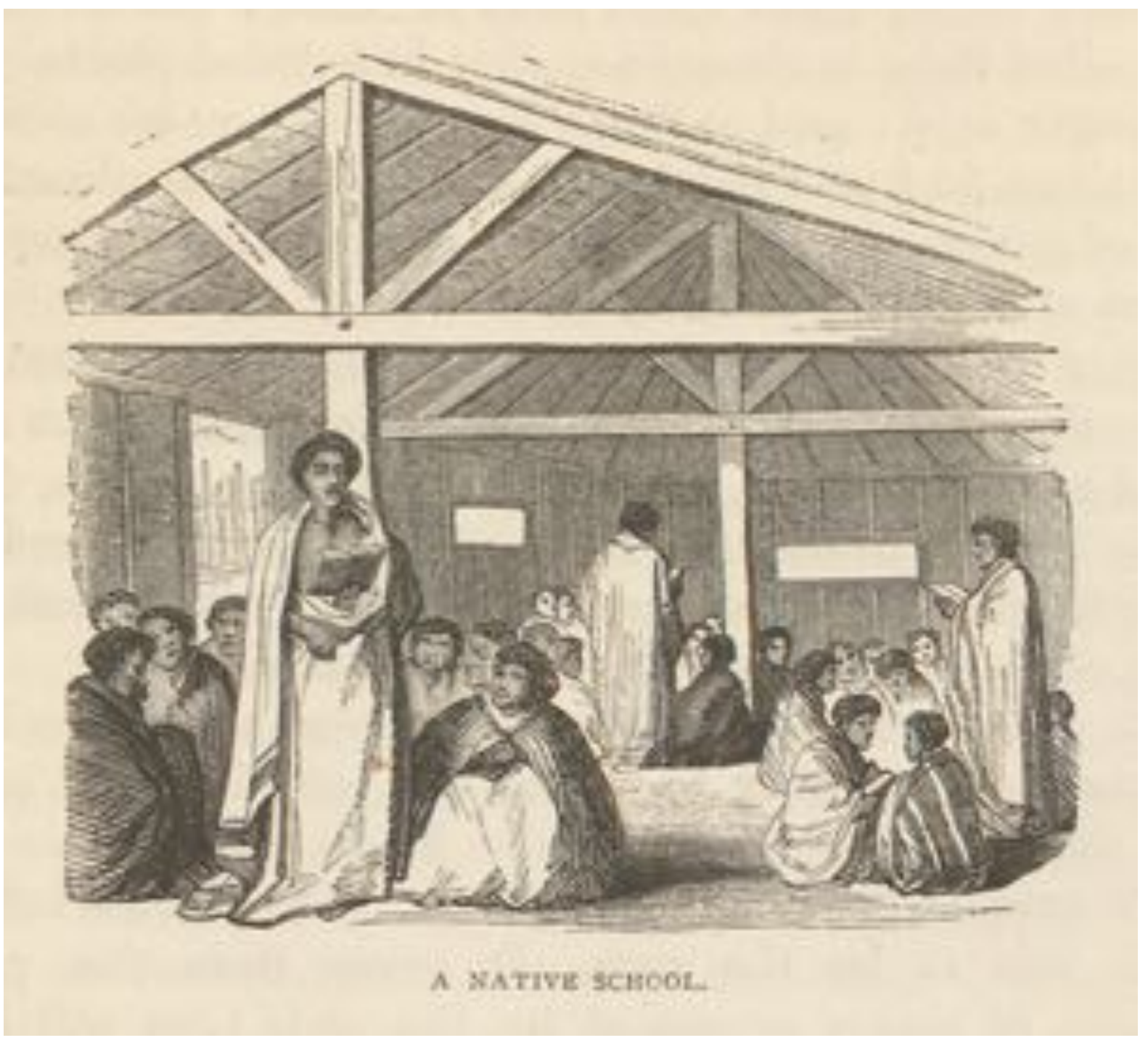

Figure 3. Illustration from Richard Taylor, The Past and Present of New Zealand; With Its Prospects for the Future. With Numerous Illustrations, (London and New Zealand: William Macintosh and Henry Ireson Jones, 1868), p. 87.

\footnotetext{
${ }^{1}$ Hana O’Regan, Ko Tahu, Ko Au: Kāi Tahu Tribal Identity, (Wellington: Horomaka Publishing, 2001), pp.38-39.
} 


\section{Introduction}

Native schools were "complex and contradictory." 2 Prior to European contact Māori had their own traditional forms of educating their youth. With the arrival of Pākehā, small primary schools for Māori 'education' were erected throughout the country. Initially called missionary schools, they were founded on providing the children with religion and basic literacy which would lead to 'civilising' Māori to a Pākehā 'temperament.' They were a tool for assimilating and exploiting but they also did provide opportunity to Māori. ${ }^{3}$ This chapter looks at the legislation and legal administration that implemented the Pākehā ideology that Māori were 'better suited' to vocational education. The colonisation-through-education process occurred when a British structure was superimposed on to Māori. This structure included a system that categorised race. The system was paradoxical as the racial (and ideological) rankings meant a simultaneous inclusion and exclusion of mixed-race children. The children were provided opportunities through the education system, but these came with conditions. The consequences of Native Schools directly contributed to Māori self-identity complexes. In the nineteenth century, New Zealand educational policies "privileged exclusive identities based on essentialist notions." ${ }^{4}$ The first half of this chapter outlines major legislative moves in the nineteenth century regarding education. The early twentieth century saw the creation of a cacophony of policy to do with Māori education. As you often cannot disentangle 'Māori' and 'half-caste' education, to understand what happened to mixed-race Māori, one must understand the general context of educational policy. Consequently, in the latter half of this chapter, I will move from a chronological outline to more thematic groupings. As this thesis' focus is on state policy, the discussion on secondary schooling will not include church run secondary schools. Finally, oral interviews with self-identified mixed-race Māori contextualise the continuation of inclusion and exclusion in the education system today.

\section{Background}

Prior to the signing of the Treaty of Waitangi in 1840, Christian missionaries set up schools for Māori children that were for religious learning, industrial training and academic education. ${ }^{4}$ These had to be instructed in te reo and not English for pragmatic reasons, chiefly, most of the country's population spoke te reo. There was little animosity towards the schools and Māori chiefs were happy to sponsor schools that extended Māori knowledge to English language and Christianity. ${ }^{5}$ However, post-treaty New Zealand saw a Pākehā shift from

\footnotetext{
2 J. Simon (ed.), L. Smith, G. Smith, S. McNaughton, K. Matthews, W. Smith, L. Pīhama I. Hēperi, V. Tuteao, Ngā Kura Māori: The Native Schools System 1867-1969 (Auckland: Auckland University Press, 1998), p. 2.

${ }^{3}$ Ngā Kura Māori: The Native Schools System 1867-1969, p. 2.

${ }^{4}$ Farida Fozdar and Maureen Perkins, 'Antipodean Mixed Race: Australia and New Zealand', in Rebecca C. King-O'Riain, Stephen Small, Minelle Mahtani, Miri Song, Paul Spickard (eds.), Global Mixed Race (New York: NYU Press, 2014), p. 139.

${ }_{5}^{5}$ Bernard Spolsky, 'Reassessing Māori Regeneration', Language in Society, Vol. 32, no. 2, September 2003, p. 556.
} 
enabling meaningful interactions through education to "civilizing and pacifying the Māori" through missionary schools. ${ }^{6}$

As chapter two stressed, land was an issue of the utmost contention between Pākehā and Māori. The best way to illustrate the shift of Pākehā ideology on Māori education posttreaty is through land. In 1844, Te Āti Awa leader, Wiremu Te Rangitake, saw that his iwi's land at Waitara could potentially be seized through government ratification of a New Zealand Company claim to the land. ${ }^{7}$ Te Rangitake wrote a letter to the governor of the country at the time, Robert FitzRoy. In it he stated "Friend, Governor, do you not love your land-England, the land of your fathers - as we also love our land at Waitara?" 8 FitzRoy did not agree with the Land Claims Commissioner, William Spain, that the country recognise the New Zealand Company's claim to Waitara. FitzRoy was, instead, "aided in his inquiries by those best acquainted with the Maoris [such as missionaries] and versed in their customs, he obtained the consent of the Maoris to an arrangement by which a block of land was secured for the New Zealand Company by payment of a small sum of money." Pākehā were upset with FitzRoy as they believed that the governor acted with too much affection and care for Māori and their customs, as well as being "spurred on by the missionary clique to dispossess the Company of the finest territory they had ever acquired." 10

With this context in mind, it is possible to see that Pākehā saw George Grey as a more than attractive candidate to govern the country post-FitzRoy. Before Grey's first term as governor he had served in South Australia, where he wrote a travel journal between 1837 to 1839. The journal illustrates Grey's character and ideals and how they informed his 1847 Ordinance for Promoting the Education of Youth in the Colony of New Zealand. ${ }^{11}$ Grey's journal showed he wished to bring European ideas of civilisation to the aboriginal populations of the countries he served in. Grey believed that aboriginals "must disappear before advancing civilization, successively dying off" or they must show "the truths of Christianity or the benefits of civilization."12 Such 'truths' and 'benefits' could be attained through education.

\section{The 1847 Education Ordinance}

Many ordinances enacted post-treaty were motivated by the establishment of a settler society. Aside from the adoption of laws from New South Wales, the focus was heavily set on law and order. The first decade of post-treaty ordinances concerned the formation of courts,

\footnotetext{
${ }^{6}$ ibid.

${ }^{7}$ George William Rusden (ed.), Aureretanga: Groans of the Maoris, (London: William Ridgway, 1888), p. 12.

8 ibid.

9 ibid.

10 ibid.

11 An Ordinance for Promoting the Education of Youth in the Colony of New Zealand, 7 October 1847.

12 George Grey, Journals of Two Expeditions of Discovery in North-West and Western Australia, During the Years 1837, 38, and 39 (London: T and W Boone, 1841); accessed January 122019.
} 
military and police as well organising religion, land, marriage, and education. ${ }^{13}$ Education was of great concern to the governing powers in these early decades. The 1847 Education Ordinance was introduced to actively encourage education and ensure pedagogy towards children be founded on three categories; religious education, industrial training, and "instruction in the English language."14 The Ordinance's wording was not targeted towards 'half-caste' and Pākehā children, but it did not explicitly exclude them either. In fact, there was no specification of which children they were promoting to educate. However, it was created for "Native children" as was made explicit by Grey's NZLC. ${ }^{15}$ It was stated that "the aborigines forming the great bulk of the population, were eager for education, as well as instruction in agriculture and other industrial arts, by which they might be made better subjects, and serve powerfully to develop the resources of the Colony." 16 The discussion included the elaboration that "though not intended to exclude European children, the bill was intended mainly to provide for the education of children of the native race."17 The targeted approach to Māori indicates that the main foundational document of education in post-treaty New Zealand saw children as resources. However, the children were 'resources' that needed to be 'improved' to become 'better' citizens.

The 1847 Ordinance allocated public funds to schools that were established or were to be established and maintained. ${ }^{18}$ Established schools were usually those set up by missionaries and the Ordinance authorised the annual inspection, reporting and publishing of a school's competence. ${ }^{19}$ The schools were to be managed by leaders connected to a religious body which included The Bishop of New Zealand, The Bishop or Head of the Roman Catholic Church in New Zealand, the Superintendent of the Wesleyan Mission and any other head of a religious body who had proven experience educating children in New Zealand. ${ }^{20}$ Education was synonymous with missionary work. The introduction of the 1847 Ordinance was not the end of missionary schools and the beginning of Native Schools, it was the continuation of treating Māori children as uncivilised offspring that needed to be saved by God. The Ordinance is comparable to the interdenominational 'ragged' day schools of the United Kingdom in the midnineteenth century. 'Ragged' schools were usually for lower class, disadvantaged children that taught with a focus on vocational instruction and basic literacy and numeracy. ${ }^{21}$ The children

\footnotetext{
13 'Early New Zealand Statutes and Ordinances 1841-1940', The University of Auckland New Zealand, accessed 2 August 2019.

${ }_{14}$ An Ordinance for Promoting the Education of Youth in the Colony of New Zealand, 7 October 1847, s. 3.

15 'Legislative Council', New Zealand Spectator and Cook's Strait Guardian, 10 November 1847, p. 3.

16 ibid.

17 ibid.

${ }^{18}$ An Ordinance for Promoting the Education of Youth in the Colony of New Zealand, 7 October 1847, s. 1.

19 ibid., s. 2.

20 ibid., s. 10.

${ }^{21}$ Laura M Mair, 'They 'Come for a Lark': London Ragged School Union Teaching Advice in Practice, 1844-70', Churches and Education, Vol. 55, June 2019, p. 325.
} 
of such schools were associated with bad behaviour and morals but "God's love and saving work through Jesus Christ was at the core of a ragged school education."22 This 'saving' would lead to improvement. It is likely that the leaders of settler society in New Zealand were aware of this method of education from their homeland to 'civilise' the 'immoral' and imparted the ideology onto Native Schools.

Missionary schools, prior to the 1847 Ordinance, were private provisions with their own religious agendas that they could uphold with relative freedom. ${ }^{23}$ The 1847 Ordinance was not an offence to those liberties, but the enticement of funding had a synergising impact on both the missionaries' and the State's agendas. The NZLC recognised that the already established denominations who had opened Missionary Schools were financially frugal while simultaneously having "succeeded to such an extent as they had done, in raising the native population from the grossest barbarism to Christianity, and an eagerness after farther instruction and advancement in civilization." ${ }^{24}$ The NZLC supposed that the 1847 Ordinance was a result of the missionary schools success through "benevolence." ${ }^{25}$ The 1847 Ordinance's religious undertones recognised the important role religion plays in assimilation. However, vocational pedagogy, basic arithmetic and reading, and full instruction and immersion in English were just as important.

Settler authority had to mitigate the risk of losing Māori children from being productive subjects of the Colony. One such danger to avoid was secular education to educate Māori youth. This risk was articulated by the NZLC by drawing comparisons to France. Secular education introduced during Napoleon I's reign (1804-1814, 1815) was described as the cause of children who were "impious," morally corrupt, and "revolutionary" in a way that was a risk to colonial harmony. ${ }^{26}$ The NZLC noted what they believed to be a causative link between the increase in crime and the introduction of secular education in France. This was considered a fate that needed to be avoided at all costs in New Zealand. ${ }^{27}$ It was imperative that in New Zealand "intellectual instruction must be subordinate to the regulation of the thoughts and habits of the children, by the doctrines and precepts of revealed religion." 28 The Attorney General, William Swainson, believed that failure to indoctrinate children through the education system "would certainly fail in producing the desired result." 29 The State's underlying intention for early educational legislation was made clear by Governor Grey's advisors and their discussion on

\footnotetext{
22 ibid.

${ }^{23}$ Ngā Kura Māori: The Native Schools System 1867-1969, p. 2.

24 'Legislative Council'New Zealand Spectator and Cook's Strait Guardian, 10 November 1847, p. 3.

25 ibid.

26 ibid.

27 ibid.

28 ibid.

29 ibid.
} 
the 1847 Ordinance. The NZLC concluded that Native Schools were "chiefly for the instruction of natives, but to which European and half-caste children should be admitted." 30

\section{Declining Attendance}

In 1857, the Whanganui Industrial School began admitting "half-caste and destitute European children" due to a lack of "native" pupils in attendance. ${ }^{31}$ The drop in early Māori attendance can reasonably be attributed to the beginnings of Māori mistrusting Pākehā officialdom. These attendance issues began before the New Zealand Wars impacted Whanganui greatly in 1846. In 1841, a New Zealand Company settlement established itself in Whanganui which led to early “unresolved land disputes." ${ }^{32}$ However, Vincent O’Malley states "the most immediate cause of anger among Whanganui Māori in late 1846 was the treatment meted out to their kin, who had been executed or exiled."33 'Half-castes' admittance to schools intended for 'natives' was likely connected to Māori retaliation on settler families whereby “a number of Māori women living with Pākehā men at Whanganui left the settlement, which was seen as a sure sign that hostilities were imminent." 34 This indicates that prior to 1857 , due to the conflicts, 'half-caste' children were associated through their parents as aligning themselves with Pākehā.

Despite the main purposes of the 1847 Ordinance being for the "instruction of natives" it is important to remember the secondary specification that "European and half-caste children should be admitted" as well. ${ }^{35}$ This encapsulates the hierarchy of students in the midnineteenth-century education system; at the bottom are Māori children, then above them is 'half-caste' children, and above them is orphaned and/or poor Pākehā children. This shows an imposed form of inter and intra-racial racism. A report presented to the House of Representatives stated that "towards the close of the year 1856, the hostilities which had so long prevailed seemed to be likely to cease." ${ }^{36}$ However, while Māori students remained the majority, they were no longer exclusive in schools due to declining attendance.

The escalation of the New Zealand Wars in the mid-nineteenth-century had considerable influence on the lower rates of attendance of Māori students and the increase in 'half-caste' and Pākehā students at missionary schools. Many Māori men, women and children were killed, and exact numbers are not known, given that "British military commanders and colonial authorities underplayed the full extent of such casualties." ${ }^{37}$ Other consequences of

\footnotetext{
30 ibid.

31 'Reports on Native Schools', AJHR, Session 1, E-1, 16 June 1858, p. 51.

32 Vincent O’Malley, The New Zealand Wars: Ngā Pakanga o Aotearoa, (Wellington: Bridget Williams Books, 2019), pp. 73-74.

33 ibid.

34 ibid., p. 75.

35 'Legislative Council', New Zealand Spectator and Cook's Strait Guardian, 10 November 1847, p. 3.

36 'Reports on Native Schools', AJHR, Session 1, E-1, 16 June 1858, p. 52.

37 Vincent O’Malley, The New Zealand Wars: Ngā Pakanga o Aotearoa, p. 18.
} 
war would also have affected school attendance, such as homelessness and the orphaning of many Māori children.

\section{'To the Parents of Half-Caste Children in New Zealand'}

Joseph Jenner Merrett, was a Pākehā artist, poet, trader and Māori interpreter, born in England in $1816 .{ }^{38}$ Merrett took up residence in Auckland where he married Maria Rangitetaea of Ngāti Kura. ${ }^{39}$ Between 1845-1847, Governor Grey took Merrett under his patronage for his art, this benefaction clearly influenced Merrett's complimentary views on Grey. ${ }^{40}$ Merrett wrote a letter in 1847 published in the New Zealander titled "To the Parents of Half-Caste Children in New Zealand." 41 Merrett wrote of Governor Grey's favourable views towards mixed-race children and the importance of European influence:

I deeply esteem him that he is willing and anxious to improve the half caste children; who, from their personal advantages, combined with their natural intelligence, deserve the attention of the Government, even if they make it an act of charity in bestowing it. ${ }^{42}$

Merrett is grateful to Grey for his compassion towards mixed-race children and differentiates them from Pākehā and Māori by noting their unusual situation of coming from both. The children's parentage is seen by Merrett as a potential detriment however he is also aware of the advantages mixed-race children have compared to Māori children. Though he is unclear about the advantages, there are many possible allusions.

Merrett placed blame on absent Pākehā fathers not supporting their mixed-race children's plight against "the state of degradation, from whence their mothers sprung." ${ }^{43}$ This belief in the inferior social circumstances of mixed-race children was not unusual, as even a school inspector stated, "nothing will tend more to improve their moral and social condition than schools." ${ }^{44}$ The absent Pākehā father argument was raised at an 1857 Education Officials meeting regarding New Zealand's Industrial Schools. Pākehā who attended the meeting were "invited to submit their opinions respecting the Half-Caste children in the school." 45 One suggestion was that school attendance by mixed-race students had dropped due "to the neglect of the mothers of those children who have been deserted by their father." 46 A storekeeper from

\footnotetext{
38 Vincent O' Sullivan, 'Joseph Jenner Merrett' in Roger Robinson and Nelson Wattie (eds.), The Oxford Companion to New Zealand Literature, Online Version, (Oxford: Oxford University Press, 2006), np. Web. Accessed 27 Aug. 2019, from https://www.oxfordreference.com/view/10.1093/acref/9780195583489.001.0001/acref-9780195583489-e-802.

${ }^{39}$ Una Platt, Nineteenth Century New Zealand Artists: A Guide and Handbook, (Christchurch: Avon Fine Prints, 1980), p. 168.

40 ibid.

41 Joseph Jenner Merrett, 'To The Parents of Half-caste Children in New Zealand', New Zealander, 9 October 1847, p. 3.

42 ibid.

43 ibid.

44 'Native Schools: Reports of Inspectors Presented to Both Houses of The General Assembly Pursuant to Act 21 \& 22 VIC. C. 55', AJHR, Session 1, E-9, 1863.

45 'Reports on Native Schools', AJHR, Session 1, E-1, 16 June 1858, p. 57.

46 ibid.
} 
Ōtaki, Richard Eager, shared his opinion that "there is a strong disinclination amongst the parents of Half-Caste children at Otaki to send their children to the School while it is under a Maori master only...there are some 30 half-caste children who have been deserted by their fathers. ${ }^{47}$ Eager saw it imperative that there be a Pākehā male who could influence the children to ensure that the child was not solely exposed to Māori ways of life at home as well as at school. Māori responses greatly differed from that of Pākehā, particularly from Māori nationalist and religious movement leaders. Many Māori "continued to oppose the establishment of schools" into the early twentieth century. ${ }^{48}$ Reasons included being "part of a general rejection of European institutions; a wish to maintain traditional Māori language, beliefs and social organisation; or because of continuing resentment over land confiscations."49

The order of Māori at the bottom, mixed-race above and Pākehā at the top also converges with the notion of infantilising white women, and to a lesser degree, mixed-race women. Education was imperative for mixed-race women but less so for Māori women, parliamentarian Hugh Francis Carleton stated "in consequence of their peculiar position, they [mixed-race women] need more careful attention than the women of purely native Race... if well brought up they readily obtain European husbands; but, unless they be respectably married, their usual fate is all well too known." ${ }^{50}$ Merrett's aforementioned letter argued that education would ensure the protection of mixed-race women writing, "it makes my blood boil with indignation, when I see the friendless, homeless, daughters of Europeans, by native women, with their delicate and interesting features and persons, wandering about, the victims of prostitution and disease." ${ }^{51}$ The main feature Merrett is referring to of mixed-race women is their lighter skin, not quite white, but not dark either. This colourism has a white man impose intra-racial racism onto Māori women.

Reverend John Morgan, headmaster of the missionary school in Otawhao, King Country, was dissatisfied with Pākehā fathers' disregard of their mixed-race children. Morgan believed it was imperative the children attend the schools to avoid "poverty, ignorance and vice, and from the degradation of being brought up as Maoris." ${ }^{.52}$ Mixed-race children were treated differently to and better than Māori, regardless of whether instructed to in legislation. Morgan vehemently believed that a school where "half-castes" should attend with "Natives" would "considerably retard the Half Caste children in the acquisition of English language." 53

\footnotetext{
47 ibid.

48 John Barrington, Separate but Equal? Māori Schools and the Crown 1867-1969, (Wellington: Victoria University Press, 2008), p. 46.

49 ibid. p. 19.

50 'Reports on Native Schools', AJHR, Session 1, E-1, 16 June 1858, p. 77.

51 Joseph Jenner Merrett, p. 3.

52 John Morgan to C.S, 6 April 1848 in in J.M Barrington and T.H. Beaglehole, Maori Schools in a Changing Society, (Wellington: New Zealand Council for Education Research, 1974), p. 51.

53 John Morgan to Grey, 4 April 1850 in J.M Barrington and T.H. Beaglehole, Maori Schools in a Changing Society, p. 51.
} 
When the school begun opening its doors to all Māori students due to low student enrolment, superior accommodation and food was set aside for the 'half-caste' children that Māori children would not receive. ${ }^{54}$ By the mid-nineteenth-century, Otawhao school was a mixture of Māori and mixed children. Despite Morgan's teaching and interventionism over 'half-caste' students, both Māori and mixed children were "indistinguishable both socially and intellectually." 55

An 1860 Report of Inspectors of Native Schools shows clear preferential treatment of mixed-race children throughout the country. Very rarely were Māori children given meat for dinner at the schools while, "the Half-Castes get meat generally every day for dinner." ${ }^{56}$ In 1862, Kawhia School had "half-caste boys sleep under the manager's roof; the rest of the pupils in the room off the new dining room." 57 There was also a noticeable difference in names between those marked as 'half-caste' children and those marked as Māori children on 1860 school attendance books. ${ }^{58}$ For the latter there were the likes of Arihia Karamana and Hopia Waretini, and for the former there were students named Catherine Green, Philomena Aldy, and Josephine Baker. ${ }^{59}$ Not only names, the standard of which education was being received by Māori and 'half-caste' children was different. Exemplifying this succinctly, St. Mary's Roman Catholic School in Auckland was inspected in 1863, it was noted that "the two half-castes receive more systematic instruction than the other Native pupils who reside at a distance." ${ }^{\circ 0}$

\section{Native Schools Acts}

Joseph Jenner Merrett's aforementioned letter in 1847 also petitioned the New Zealand public to "individually and collectively, appeal to [Governor Grey], whether these [mixed-race] children are not deserving of his consideration, and worthy of being made loyal subjects of the Queen, which they would become, if educated under the patronage of the Government." ${ }^{61}$ In 1858, this patronage was realised by the Native Schools Act. ${ }^{62}$ The 1858 Act granted public funding of a part-subsidy of $£ 100$ per year over seven years to be made to the superintendents of provinces and to be "proportionate to the number of Scholars." ${ }^{63}$ It also required attendance records and proof of such attendance to be provided to inspectors. ${ }^{64}$ If the 1847 Education Ordinance included a stipulation regarding instruction being in English, the 1858 Native

\footnotetext{
54 ibid.

55 J.M Barrington and T.H. Beaglehole, Maori Schools in a Changing Society, p. 52.

56 'Papers Relative to Native Education: Being Reports of Inspectors of Native Schools', AJHR, Session 1, E-8, 23 August 1860, p. 5.

57 ibid.

58 ibid., p. 22.

59 ibid.

60 'Native Schools: Reports of Inspectors Presented to Both Houses of The General Assembly Pursuant to Act 21 \& 22 VIC.

C. 55', AJHR, Session 1, E-9, 1863, p. 9 .

${ }^{61}$ Joseph Jenner Merrett, p. 3.

62 Native Schools Act 1858.

63 ibid., s. 3.

64 ibid., s. 7.
} 
Schools Act hardened this with "a more strident English-only approach" in the classroom. ${ }^{65}$ The government argued Māori civilisation and integration with Pākehā could be advanced through a shared language, an efficient way to break the barriers of discourse for harmonious race relations. ${ }^{66}$

The Native Schools Act 1867 officially established a central system for Native Schools in New Zealand to be run by and subsidised by the Government. ${ }^{67}$ When debated in parliament the main support came from an economic perspective where war had cost the government a lot of money and Hugh Carleton was of the opinion that "things had now come to pass that it was necessary either to exterminate the Natives or civilise them." 68 Government grants were to be calculated according to school attendance and preference was given to students showing "proficiency in the English language and in the knowledge of reading writing and arithmetic." 69 The 1867 Act was explicit in specifying whose education the Government would subsidise, being primarily "children of the aboriginal native race and of half-castes being orphans or being the children of indigent persons." $" 70$ The wording of this suggests that mixed-race children are not deemed Māori unless through the intersections of class where they are without one or both parents and/or through destitution.

During the early 1860 s, the disruption of the New Zealand Wars saw native school inspectors perceive the reservations held by Māori parents and caregivers, preventing them from sending their children through this system, as undoing the "good" done by the Government. ${ }^{71}$ In the eyes of inspectors it was seemingly preposterous that Māori could believe "the Government had some ulterior object beyond the welfare of their children in establishing Schools." 72 Their line of thinking was that "Natives" should be thankful for the education they were receiving. ${ }^{73}$ Adding to the climate of antagonism and growing disenchantment with the schools, Major Charles Heaphy V.C. stated in the parliamentary debate in 1867 on the "Maori Schools Bill" that "there could be no doubt that the Natives had retrograded in respect to education." ${ }^{74}$ Heaphy argued that the pull away from education not only correlated with but was a contributing causative factor in crime rates rising along with police expenditure. ${ }^{75}$

\footnotetext{
65 John Barrington, Separate but Equal? Māori Schools and the Crown 1867-1969, p. 19.

66 ibid.

${ }^{67}$ Ngā Kura Māori: The Native Schools System 1867-1969, p. 11.

${ }^{68}$ Hugh Carleton, NZPD, 1867, Vol. 1(2), p. 863.

${ }^{69}$ Native Schools Act 1867.

70 ibid., s. 3.

71 'Native Schools: Reports of Inspectors Presented to Both Houses of The General Assembly Pursuant to Act 21 \& 22 VIC.

C. 55', AJHR, Session 1, E-9, 1863, p. 1.

72 ibid., pp. 1-2.

73 ibid.

${ }^{74}$ Major Charles Heaphy V.C., NZPD, 1867, Vol. 1(2), p. 863.

75 ibid.
} 
In the parliamentary debate of the bill in 1867, it was mooted that Māori needed to contribute more to ensure a good Pākehā education for their children. It was suggested that they could utilise their already dwindling land reserves to contribute to a school, through Government insistence on "contributing something in land, labour, or money." "76 Carleton believed the government could no longer afford to continue fighting a war, relaying that the economy in a dire financial position, therefore Carleton argued that "all that the Government could do with the Natives must be done by moral influence." 77 The notion that force should not be used played into the idea that Māori would not bend to force. As though less than human, Carleton believed in 1867 that Māori "did not fear death...they could be crushed, they could be exterminated, by they could not by force be brought into subjection." 78

Though the ultimate consequences of the Native Schools Acts would take years to be fully realised, "it was the major step in the shift of Māori speakers from Māori monolingualism, through an intermediate stage of bilingualism, to English monolingualism”, despite Māori reluctance to lose te reo. ${ }^{79}$ Politician Henry Tancred noted that prior to 1867 , native schools were less of a triumph than anticipated, however, the 1867 Act was not as revolutionary as hoped. ${ }^{80}$ A system that was the same throughout the country was fine if those for whom the system was created actually wanted to use it. ${ }^{81}$ By 1871 , certain stipulations were repealed as there was a lack of schools being sponsored by Māori due to the land and materials required and the cost for Māori to maintain the buildings and teacher salaries. ${ }^{82}$ By this point the popularity of the schools to Māori communities in different pockets of the country varied. On the East Coast and at the top of the North Island there had been less distress from the Wars and a more optimistic approach. ${ }^{83}$ However, in areas such as Taranaki and Waikato, where the Wars had affected their communities more devastatingly, the Act was generally ignored. ${ }^{84}$

Member of Parliament, Alfred Brandon, stated in the parliamentary debate on the 1867 Act that he was in favour of what it stood for as:

The work which the Colony ought to endeavour to do for the remnant of a race which had been the owners and occupiers of the land before Europeans came to it, was to save them from extinction; this was a work of interest to all New Zealand colonists. After all, what were they [parliamentarian dissenters to the Act] asked to sacrifice? They were

\footnotetext{
${ }^{76}$ Hugh Carleton, NZPD, 1867, Vol. 1(2), p. 863.

77 ibid.

78 ibid.

${ }^{79}$ Bernard Spolsky, 'Reassessing Māori Regeneration', p. 557.

${ }^{80}$ Henry Tancred, NZPD, 1867, Vol. 1(2), p. 865

81 ibid.

${ }^{82}$ Ngā Kura Māori: The Native Schools System 1867-1969, p. 12.

83 ibid.

84 ibid.
} 
asked to grant, out of an annual revenue of a million of money, the miserable, the paltry sum of $£ 4000 .^{85}$

Unlike Carleton, Brandon framed the financial situation of the country differently. Brandon did not consider education as the cheaper method to morally control Māori if "extermination" through war was too expensive on the government's pockets. Brandon believed Māori were to be encouraged to look after their own schools to advance their own people, but Pākehā had an obligation (and more than enough means) to grant funds to allow Māori to self-govern. This peculiar form of paternalism forms an idea of an interdependent trust between Pākehā and Māori.

\section{Māori Petitions and Protest}

Māori opinion on Native Schools could not and should not be considered as collective during the period following the 1867 Act. Wi Te Hakiro and 336 others signed a petition in 1876 presenting an amendment to the House of Representatives that within the Native Schools scheme there needed to be two systems to educate Māori children. ${ }^{86}$ The petition was paradoxically written in Māori with an English translation underneath. It is not clear who translated the document but beneath the English version there is the stamp of the Government Printer, George Didsbury. The following petition interpretations are based off the English translation and those from other historians.

The first system suggested in the petition was for Māori children who already spoke te reo and whose world was a Māori one. For these children it was recommended that they should receive a syllabus that was immersive in te reo rather than retroactively learning English. ${ }^{87}$ For the second system it was proposed that when Māori children reached the age of two they "should be taught the English language, and all the knowledge which you the Europeans possess...our children will soon attain to the acquirements of the Europeans." 88 In the petition it also suggested that there should not be separation in the playground between Pākehā and Māori children and that play would be conducted in English. The petitioners saw it proper that "there should not be a word of Maori allowed to be spoken in the school... the master, his wife and children should be persons altogether ignorant of the Maori language." 89 A substantial number of Māori invested in the politics and proceedings of Native Schools deemed it imperative that the hard-line approach be followed.

Judith Simon and Linda Tuhiwai Smith state that other school committees (with predominantly Māori members) throughout the country adapted their own restrictions like

\footnotetext{
85 Alfred Brandon, NZPD, 1867, Vol. 1(2), p. 866.

86 'Petition of Wi Te Hakiro and 336 Others', AJHR, Session 1, J-4, 29 June 1876.

87 ibid.

88 ibid.

89 ibid.
} 
those mentioned in the petition and in the many other petitions presented. ${ }^{90}$ Simon and Smith explain that Karaitiana Takamoana, a new Māori Member of Parliament who served between 1871-1879, "sought legislation to ensure that Māori children were taught only in English."91 This is a turning point in the cog of Māori education in the late nineteenth century from one of resistance to one of elementary existence. As Simon and Smith argue "before the wars [Māori] focus had been on avoiding disadvantage in relation to Pākehā, their focus now was on surviving economically and politically within a Pākehā-dominated society." 92 Of course, there were dissenters, as mentioned earlier, and attendance was sporadic due to land court hearings after the wars. There was also "continued resistance to assimilation and resentment of Pākehā control by those Maori who remained bitter after defeat in war and subsequent land confiscation. ${ }^{93}$ It is of no surprise that those hardest hit by the War were ardently against Native Schools.

\section{The Education Act 1877}

The Education Act 1877 established the Department of Education and a Minister of Education. ${ }^{94}$ Within the department there was to be a general inspector and staff to perform the required responsibilities relating to the education department. ${ }^{95}$ This was a central system introduced to organise the education of the country's youth in a way that was free (paid for by the tax-payer), secular, and enforced compulsory attendance. This was the year after the provincial governments were abolished and was one of the first pieces of legislation that demonstrated increased control of the new centralising state over education. There was debate about the promises made in the Act (free, secular, compulsory) being too onerous for the Government to uphold. The debates concerning free education were over cost and Morgan Stanislaus Grace argued to other NZLC members that the Government was "entering upon a very dangerous course financially." 96 The debates about attendance, on the other hand, usually concerned whether the State should have greater authority than that of a parent. NZLC member, James Menzies, countered the concerns by stating that "the future welfare of the State depends upon the nature of the education given to the rising generation." 97 Those who did dissent free, secular and compulsory education usually had intentions that were based on their own personal grievances about fiscal and parental responsibility.

\footnotetext{
90 Judith Simon and Linda Tuhiwai Smith, A Civilising Mission? Perceptions and Representations of the Native Schools System, (Auckland: Auckland University Press, 2001), p. 164.

91 ibid.

92 ibid., p. 165.

93 J.M Barrington and T.H. Beaglehole, Maori Schools in a Changing Society, p. 125.

${ }_{94}$ Daniel Pollen, NZPD, 1877, Vol. 26, pp. 119-120.

95 ibid.

${ }^{96}$ Morgan Stanislaus Grace, NZPD, 1877, Vol. 26, p. 126.

97 James Menzies, NZPD, 1877, Vol. 26, p. 121.
} 
Just as the Native Schools Act 1867 made no explicit exclusion of Pākehā children, the 1877 Education Act was clever in its wording. It did not exclude Māori, but made it appear the choice belonged to Māori. The 1877 Act stated:

Nothing in this Act shall be binding on any Maori; but any Maori shall be at liberty to send his children to a public school under this Act, subject to the regulations for the time being in force in such school. The word "Maori" shall include every person of the aboriginal race of New Zealand and every person one of whose parents was a native of such race: But no half-caste shall be deemed to be a Maori within the interpretation of this Act unless he shall be living as a member of some Native tribe or community. ${ }^{98}$

What is telling is the stipulation that 'half-caste' shall not be considered Māori unless well involved in their iwi and hapū. It can be deduced that any Māori who were not with their iwi and tribe were Pākehā enough to be under the 1877 Education Act. By 1878, New Zealand had "two parallel systems operating" and the Education Department was unified to be more cohesive with both public schools and now native schools under the direction of the education board system introduced in the 1877 Act. ${ }^{99}$ By 1880, due to this merger, "Native Schools were more systematically managed than before." 100

\section{Native Schools Code 1880}

By 1880, The Native Schools Code was created as a point of reference to standardise how Native Schools were teaching their pupils across the country by James Pope. ${ }^{101}$ James Pope was only appointed in January 1880 to the role of inspector general of schools. ${ }^{102}$ Pope was considered the best man to unify the school system due to his successful teaching of history at Otago Boys and Otago Girls High Schools and in the Taranaki region. ${ }^{103}$ Creating the Code was one of Pope's first tasks, and he "made a point of travelling extensively throughout the country, visiting various Māori communities and schools, and building up sense of the state of Māori education in the country."104 Pope's concerns resulted in the 1880 Code.

Though the Code can be considered as a consolidated continuance of that which had occurred since first contact, it shows "both an unprecedentedly detailed and considered approach towards the issue of Te Reo Māori in Native Schools, and an intent by the state to

\footnotetext{
${ }^{98}$ Education Act 1877, s. 10.

${ }^{99}$ Ngā Kura Māori: The Native Schools System 1867-1969, pp. 12-13.

100 ibid., p. 13.

${ }^{101}$ Paul Moon, “To Teach the Natives English”: James Pope's 1880 Native Schools Code', History of Education, Vol 48, no. 5, 2019, p. 591.

102 Paul Moon, “To Teach the Natives English": James Pope's 1880 Native Schools Code', p. 598.

103 John Barrington, Separate but Equal? Māori Schools and the Crown 1867-1969, p.40.

104 Paul Moon, “To Teach the Natives English": James Pope's 1880 Native Schools Code', p. 598.
} 
codify more explicitly government preferences for Māori education more generally." ${ }^{105}$ The inconsistencies in the management of native schools were of Pope's greatest concern as his superior was education secretary, John Hislop, who tasked Pope to remedy the varying qualities of instruction and syllabus. ${ }^{106}$ The Code stipulated that te reo was not a prerequisite for teachers and that it only be used to ease the younger students into full English instruction. ${ }^{107}$ Pope wanted te reo to be recognised as a second language that could be used as a transitory means to reach an assimilatory goal; "the aim of the teacher, however, should be to dispense with the use of Maori as soon as possible." 108

The makeup of native school committees were to consist of "Maoris or half-castes, unless it be otherwise allowed by the Government." 109 The committees job was to oversee attendance and consider complaints about the schools before being raised to a district superintendent. ${ }^{110}$ Despite seemingly placing more control in the hands of the parents, this was transparent in its placating nature, and in reality yielded little authority. Paul Moon argues that this move of establishing Māori governance was a rally "to make the wider community play a role in the changes that Pope conceived for his new Native Schools." ${ }^{111}$ Pākehā children could attend Native Schools, but the Code insisted that Pākehā parents remember the purpose of the school was for "the instruction of Maori children" and that if there was an ethnic mixture at the school the children were to be recorded separately. ${ }^{112}$

It is articulated in the Code that 'native' is to be defined as "Maoris and half-castes" making it clear that descent mattered. ${ }^{113}$ If you could not categorically say you were Pākehā and thus be recorded on a different register, you were required to learn by the educational standard set for Māori, regardless of whether you identified as such. Moon argues that the Code and James Pope's intentions behind it were not an act of reckless removal but "a necessary and essentially humanitarian measure in order to enable Māori to play a greater role in the life of the country." 114 This deduction, like the Code, is not radical but it is the perfect description of paternalism and how it machinated in the late nineteenth century New Zealand education system. Pope believed in the 1880 Code as much as he believed in 1899 that "Hakas, poi dances, and feasting never yet saved the souls alive of any tribe or nation, and never will." 115

\section{Who Is Still Speaking Te Reo Māori?}

\footnotetext{
105 ibid., p. 592.

106 John Barrington, Separate but Equal? Māori Schools and the Crown 1867-1969, p. 40.

107 'The Native Schools Code', AJHR, Session 1, H-1, 4 June 1880, s. 2(3), p. 1.

108 ibid.

109 ibid., s. 16(1), p. 6.

110 ibid.

${ }^{111}$ Paul Moon, “To Teach the Natives English”: James Pope's 1880 Native Schools Code', p. 601.

112 'The Native Schools Code', AJHR, Session 1, H-1, 4 June 1880, s. 19(1, 2), p. 6.

113 ibid. s. 23 , p. 7.

114 Paul Moon, “To Teach the Natives English”: James Pope's 1880 Native Schools Code', p. 606.

115 'Education in Native Schools', AJHR, Session 1, E-2, 1899, p. 15
} 
Despite the increase in the number of native schools in New Zealand, by 1909 most Māori students were attending schools run by the Education Department Board ('Board schools'). One note in the 1880 Code was that native schools would aim to be transitioned to the Education Board once full competency of the English language was seen in Māori students. ${ }^{116}$ Despite language competency being the deciding factor officially and initially, overtime "ethnic composition of the school also became an influential factor in determining transfers." ${ }^{117}$ Pope's intentions were for native schools to be for Māori children, but he did not exclude Pākehā from attending the schools. William Bird, the new Native Schools Inspector saw that when there were more Pākehā students than Māori at a native school, the school would be immediately transitioned to a Board school. ${ }^{118}$

In a 1909 native schools report, Bird modified the 1880 Code where in terms of educational administration, there was less of a hyper fixation on the 'exactness' of a student's blood. In the report it defined a student who was Māori as one who was between 'full' to 'half' Māori, but a Pākehā student would include those with only one 'quarter' Māori, or anything less than a 'half.' ${ }^{119}$ Regardless of how a student was raised, or self-identified, if they were not made of 'enough' Māori, they would not be classified as such. The change of going from language competency to ethnic demography in determining a school transfer is central to this chapter's argument. Though percentage-based assessments of ethnic identities were still prevalent there seemed to be an administrative shift in 1909 from focusing on a person's exact genetic make-up to a broadening of the definitions of 'Māori' and 'European.' It can be reasonably assumed that this was to transfer more native schools into Board schools. The following tables, taken from the 1909 report, show the difference from before the change in the categorisation in 1908 , to after in 1909.

116 'The Native Schools Code', AJHR, 4 June 1880, s. 18, p. 6.

${ }_{117}$ Maxine Stephenson, 'Closing the Doors on the Maori Schools in New Zealand', Race, Ethnicity and Education, Vol. 9, no. 3, 2006, p. 311.

118 'Education in Native Schools', AJHR, Session 1, E-2, 1908, p. 13.

119 'Education in Native Schools', AJHR, Session 2, E-3, 1909, p. 22. 
Table No. 3.

Cuassification as regards Ages and Racg of Childses belonging to Nativg Schools at the end of December Quarter, 1908.

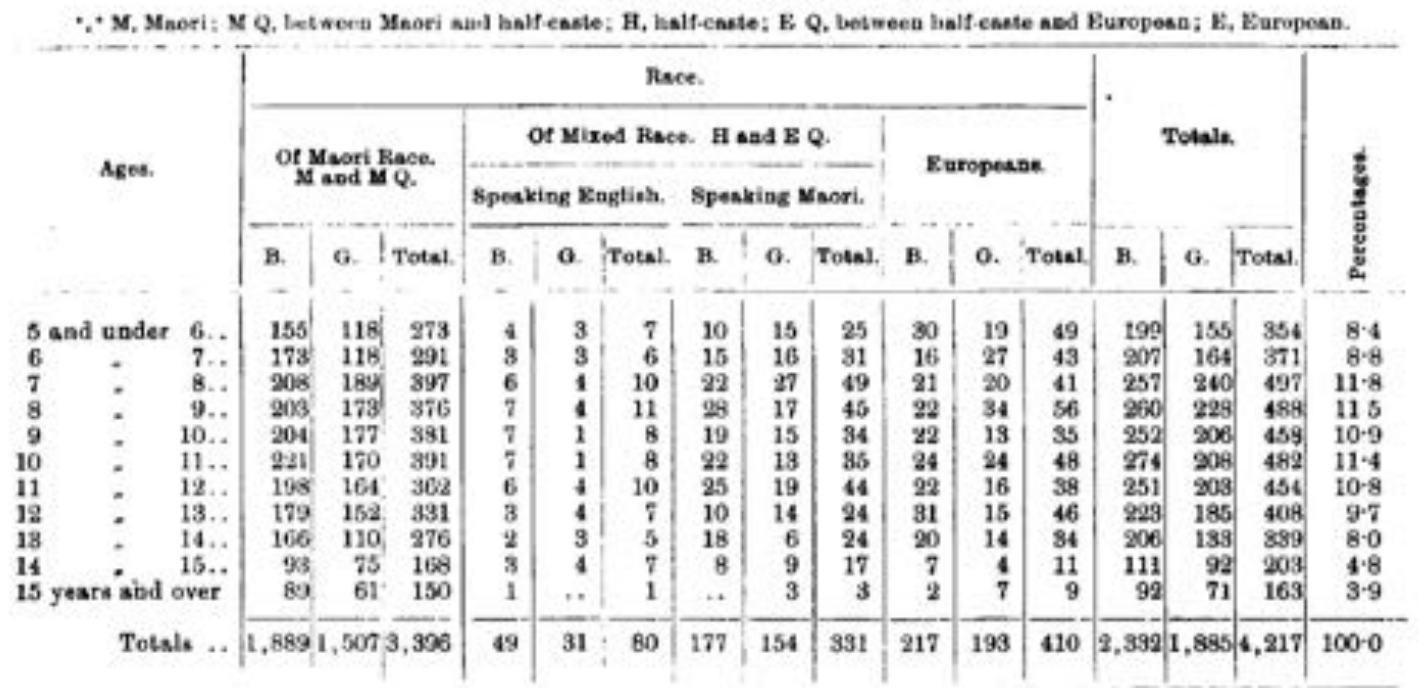

SUMMAKY OF TABLK No. 3.

\begin{tabular}{|c|c|c|c|c|c|c|c|c|}
\hline & $A g^{2}$ & & & Roye. & Girle. & Total. & $\begin{array}{l}\text { Percentage. } \\
\text { nowe. }\end{array}$ & $\begin{array}{l}\text { Poreentage, } \\
\text { 1607. }\end{array}$ \\
\hline Prom & $\begin{array}{l}\text { Eve to ten years } \\
\text { ten to fifteen years } \\
\text { ffteen upwards }\end{array}$ & $\ddot{z}$ & $\ddot{*}$ & $\begin{array}{r}1,175 \\
1,065 \\
92\end{array}$ & $\begin{array}{l}993 \\
821 \\
71\end{array}$ & $\begin{array}{r}2,168 \\
1,886 \\
163\end{array}$ & $\begin{array}{r}51 \cdot 4 \\
44 \cdot 7 \\
3-9\end{array}$ & $\begin{array}{r}59 \cdot 1 \\
41 \cdot 7 \\
3-2\end{array}$ \\
\hline & Totals & .. & $\cdots$ & 2,332 & 1,885 & 1,217 & $100-0$ & 1000 \\
\hline
\end{tabular}

Table No. 8.

Classification as regards Standazd and Raca of Pupils on the Sogoor Rolls at the End of December, 1908.

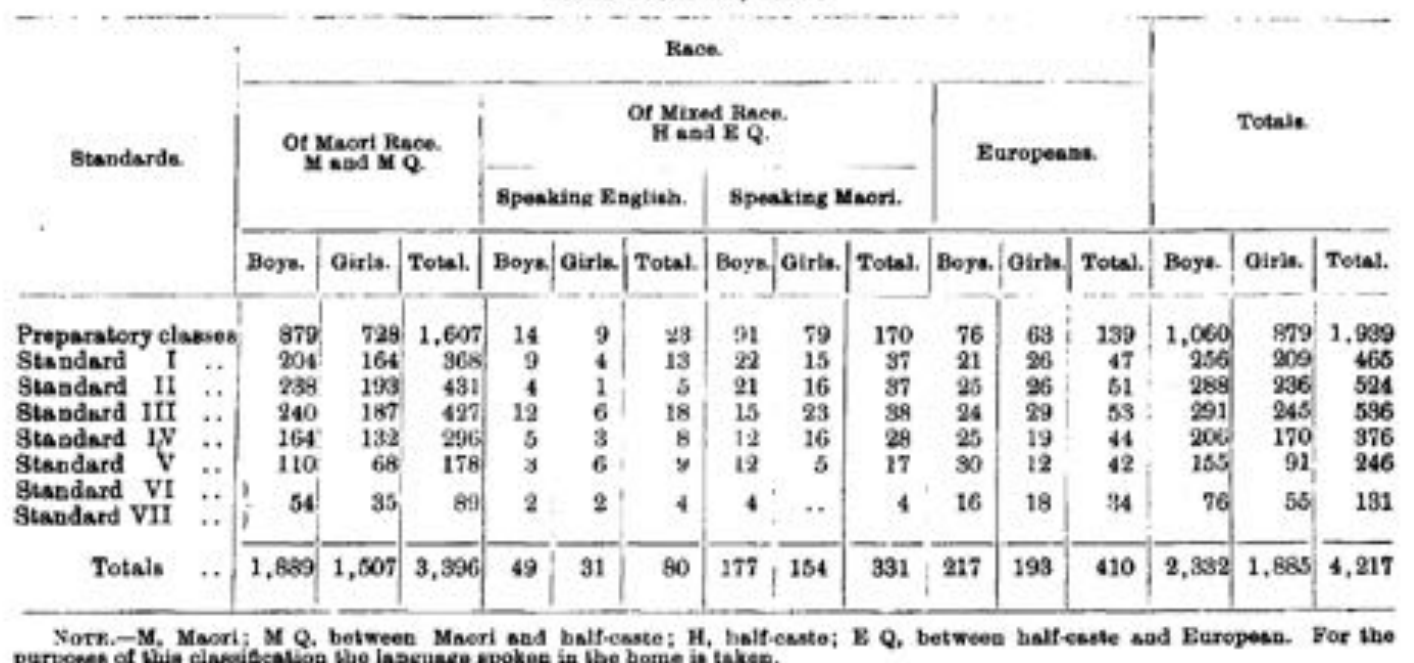

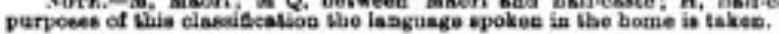

Figures 4, 5 and 6: 'Table No. 3', 'Summary of Table No. 3', 'Table No. 8' from 'Education in Native Schools', AJHR, Session 2 , E-3, 1909. 


\section{The Interwar Period}

In 1917, The Education Department published the workbook, "The Teaching of English in Native Schools: The Direct, Or Natural, Method." 120 The workbook does not lack ambiguity in the approach teachers should have with Māori children; "Do not speak to your pupils in Maori and do not permit them to speak in Maori to you, or to one another if you can help it. The less they hear of Maori the better it will be for their English." ${ }^{121}$ Aside from the syllabus being dominated by English language teaching at the expense of te reo, other historical factors contextualise the rapid loss of Māori language. Areas densely inhabited by Pākehā saw the first major decreases in the use of te reo. ${ }^{122}$ The migration of Māori to urban centres from rural areas was another factor. This migration was only exacerbated during and after the World Wars. ${ }^{123}$ In the 1920s and 1930s 'The Direct, Or Natural, Method' had made it so the only thing Māori in schools for Māori were the children themselves. ${ }^{124}$ It was not until 1931 that church-run Māori girls's schools would be approved to teach reo as a second language subject. ${ }^{125}$

The use of mixed-race children to fulfil the Education Department's needs, as seen by the 1909 expansion of the definition of European, was repeated. Just as the 1909 report showed the classification of mixed-race children change so that the number of Pākehā students would rise, in 1938 the opposite was effected. In the 1930s, the number of Māori going into any form of secondary school was very small compared to that of Pākehā students. In 1938, the inspector of native schools, Douglas Ball, stated that there were "no figures relating to the number [of Māori] attending the European secondary schools." "126 This was to appease the criticism from Āpirana Ngata regarding inadequate provisions for Māori entering secondary schools (such as distance, cost, and syllabus), the low enrolment of students at Māori secondary schools, and Ball's mentioned lack of data on Māori attendance at Pākehā State schools. ${ }^{127}$ Though it would not be until 1944 that compulsory secondary schooling was enacted and despite Ball's statement, data did exist on Māori in Pākehā State education, and that data revealed that next to no Māori attended them. ${ }^{128}$ When another data request on Māori records of attendance at these schools was conducted in 1938, the Department iterated to schools that when reporting data the definition of Māori was to strictly count "half-castes" as well. ${ }^{129}$ While still low in comparison to Pākehā student enrolments in various types of State secondary schools, the

\footnotetext{
120 The Teaching of English in Native Schools: The Direct, Or Natural, Method, (Wellington: Education Department, 1917). 121 ibid., p.6.

122 Bernard Spolsky, 'Māori Lost and Regained', in Allan Bell, Ray Harlow, Donna Starks (eds.), Languages of New Zealand, (Wellington: Victoria University Press, 2005), p. 71.

123 ibid.

124 John Barrington, Separate but Equal? Māori Schools and the Crown 1867-1969, p.17.

125 Ngā Kura Māori: The Native Schools System 1867-1969, p. 85.

126 Douglas Ball, NZPD, 1938, Vol. 253, pp. 420-421.

127 ibid.

128 John Barrington, Separate but Equal? Māori Schools and the Crown 1867-1969, pp. 227-228.

129 ibid.
} 
statistics more than doubled with the reiteration that mixed-race children needed to be counted as Māori. ${ }^{130}$ It is not a stretch to determine that this persuasive reminder to include, which lead to more favourable data, managed to pacify Māori advocates for education, if only for a little while.

\section{The Abolition and Consequences}

The Māori Schools System was disestablished in 1969 after the Advisory Committee on Māori Education made the recommendation in 1966 that by 1969, the 105 Māori schools left should be the responsibility of the Education Department. ${ }^{131}$ Though the chronological scope of this thesis spans approximately 1850-1950, there are important addenda to note before consideration can be made to the influence of 100 years of legal and administrative action in Māori education on self-identified mixed-race Māori today. In 1961, the J.K Hunn Report on the Department of Māori Affairs was released. This report was described in 1961 by Māori academic, Bruce Biggs as "a statement on the Maori situation at present, a manifesto for future action, and a theoretical discussion on the inevitability and desirability of rapid racial integration." 132 The Hunn Report was a bold statement that "called for recognition that special assistance to the Maori people was needed if living standards, occupational distribution, educational and health levels of the Maori were to be brought to approximate equality with general non-Maori standards." 133 It was flawed in its belief that by the 1980s Māori would very nearly be fully integrated as Pākehā and would have left most if not all of their culture behind. ${ }^{134}$ Biggs criticised the Hunn Report for its empty promises and Pākehā, not Māori, point of view:

The author of the Report seems impatient of cultural differences. He speaks of Maoris "complacently living a backward life", and of "reluctance to fall into line." He thinks of Maori culture as a relic of the past. Some lip service is paid to its preservation but none to its development in changing conditions. None of the one hundred odd conclusions and recommendations of the Report mention either the preservation or adaptation of Maori culture. We are warned that some Maoris who retain links with both cultures in New Zealand suffer

\footnotetext{
130 'Education of Native Children, AJHR, Session 1, E-3, 1939.

${ }_{131}$ Ngā Kura Māori: The Native Schools System 1867-1969, p. xix.

132 Bruce Biggs, 'Maori Affairs and the Hunn Report', The Journal of Polynesian Society, Vol. 70, No. 3, September 1961, p. 361.

${ }^{133}$ L.M. Kenworthy, T.B. Martindale, S.M. Sadaraka, Some Aspects of the Hunn Report: A Measure of Progress: A D.P.A Course Group Project, (Wellington: Victoria University of Wellington, 1968) as cited by John Barrington, Maori and the State: Crown-Māori Relations in New Zealand/Aotearoa, 1950-2000, (Wellington: Victoria University Press, 2009), pp. 9293.

134 Jack Kent Hunn, Report on Department of Maori Affairs: With Statistical Supplement, 24 August 1960, (Wellington: Government Printer, 1961), pp. 14-16.
} 
psychological stress as a result, but no mention is made of the equally plausible proposition that many Maoris gain psychological security from such links. And the western culture Maoris are being urged to adopt holus-bolus is probably the most stressful the world has known. ${ }^{135}$

Biggs foresaw that the security of having a mixed-heritage was being threatened by the continued removal of Māori culture.

Wally Penetito states that "how politicians decide what direction an education system will take depends much of the time on the political philosophy of those who have command of the treasury benches."136 In the second half of the twentieth century, Māori saw that "the government had effectively disaffected every sector of te ao Māori, and by the 1970s Māori were ready to communicate their frustrations publicly and angrily." 137 This created a movement of resistance towards deliberate actions which tried to remove Māori culture, such as the Hunn Report. Such actions were met with a "surge forward by Māori in promoting and revitalising the essence of what it means to be Māori." 138 This surge was especially seen through education and the establishment of kōhanga reo, kura kaupapa Māori, and wānanga in the 1980s and 1990s. In 2010, Pentito explained that the success of these versions of Māori education was due to the validation of Māori identity in a way which had never been allowed before:

Common questions and answers repeatedly reflect the priority of concerns about identity...How will the establishment of a Māori education authority improve the delivery of education to Māori? It will do exactly what the system does now and with equivalent bias, but in favour of Māori rather than the dominant system. What is it that accounts for the perceived success of kōhanga reo and kura kaupapa Māori? They acknowledge the Maori world as a valid option to be maintained in everyday life. ${ }^{139}$

By the 21st century, there was a growing awareness of the importance of multiculturalism. Attempts made in policy to appease multiple interest groups were seen, but they also raised the question of where mixed-race Māori fit, and how their educational success should be measured. An Education Review Office (ERO) report in 2010 for "Promoting Success for Māori Students" stated that "despite clear expectations from the government, the Ministry and ERO,

\footnotetext{
${ }^{135}$ Bruce Biggs, 'Maori Affairs and the Hunn Report', p. 362.

${ }^{136}$ Wally Penetito, What's Māori About Māori Education? (Wellington: Victoria University Press, 2010), p. 135.

137 Atholl Anderson, Judith Binney, Aroha Harris, Tangata Whenua: A History, (Wellington: Bridget Williams Books, 2015), p. 357.

138 Wally Penetito, What's Māori About Māori Education? p. 136.

139 ibid., p. 265.
} 
and the compelling information on Māori achievement outcomes, for a significant group of New Zealand schools Māori success is not yet given sufficiently high priority."140

Matthew described in his interview ERO visiting the college he taught at when they were compiling data for the 2010 report:

'We need to let Māori learn as Māori' that was 'the go-to' from the Ministry of Education and that was ERO coming in and doing that and ERO had gone around and talked to students and they got this false sense of - that the school wasn't catering for the Māori students and Māori staff ... ERO has made this meeting with the six Māori staff they've [ERO] all come out they've all got their massive pounamu carvings on and they're pulling them out 'showing them off' and they'd been in school about 5 or 6 days already and not once had they been wearing them. Their questioning was just so bias towards trying to make the school look like it wasn't catering to the needs of the Māori students so we explained the school bends over backwards to help Māori achievement but it's a two way street...we've got students who sit there and as soon as they flick the switch and identify as Māori they feel as though the standards required of them are lower... We've got students who don't want to identify as Māori and they get almost pressurised to do something, at the end of the day it's just tokenistic if you're force feeding those people to do it. ${ }^{141}$

Substantiating this idea of fluidity of identity and the expectations set upon themselves. In my interview with Chelsey she described how in high school she would overstate the Māori inequality she faced, “as a joke I would say I won't get things because I am brown." ${ }^{142}$ Later in the interview she states she did not take the classes known as being for 'Māori' as these were remedial and/or vocational. ${ }^{143}$ Chelsey stated her parents made sure she was in the mainstream classes because the 'Māori' classes were of a lesser standard and she should not take them if she wanted to better herself and her career prospects. ${ }^{144}$

\section{Conclusion}

The need to understand the circumstances, legislative intention and effect, and influence of native schools and the ideas of control, submission, and assimilation behind them allow for

\footnotetext{
140 Education Review Office/Te Tari Arotake Matauranga, Promoting Success for Māori Students: Schools' Progress, June 2010, (Wellington: New Zealand Government, 2010), p. 3.

141 Matthew Lambert interview conducted by Kiriana Haze, 22 May 2019, Upper Hutt, New Zealand.

142 Chelsey Aroha Brown interview conducted by Kiriana Haze, 21 June 2017, Wanuiomata, New Zealand.

143 ibid.

144 ibid.
} 
an understanding of two issues. Firstly, why special attention is given in the education system today to improve disparities between Māori and Pākehā academic achievements. Secondly, why it is important to listen to the children who experience the special attention and act accordingly. This reclamation on a macro level is one of recovery of self for my interviewees. Patricia Johnson and Leonie Pihama state that "difference is often employed in contexts which serve to uphold the interests of groups and individuals - that is, dominant groups and individuals over 'other.""145 The 1967 report and recommendations on Māori Education by the New Zealand Educational Institute stated that "Pakeha New Zealanders have a compounded sense of guilt and responsibility towards the Maoris... as long as Pakehas continue to view the social problems of a plural society through Pakeha eyes, the solution of those problem will remain slow and laborious." 146 Mixed-race children today carry the compounded guilt of historic educational inclusion and exclusion, alongside the recognition that something is still wrong, but the uncertainty of what to do about it. That has been the most staggeringly upsetting influence and legacy that educational legislation and legal administration has had on mixed-race Māori identity, that they believe they owe it to both parts of themselves to find a solution to a problem they never caused.

145 Patricia Johnson and Leonie Pihama, 'What Counts as Difference and What Differences Count: Gender, Race and the Politics of Difference', in Kathie Irwin and Irihapeti Ramsden (eds.), Toi Wāhine: The Worlds of Mãori Women, (Auckland: Penguin Books, 1995), p. 75.

${ }_{146}$ New Zealand Educational Institute, Report and Recommendations on Maori Education Presented to 1967 Annual Meeting, (Wellington: New Zealand Educational Institute, G. Deslandes Ltd., 1967), p. 11. 


\section{Chapter Four: Enumeration}

We occasionally encountered someone saying 'well we're all mixed, aren't we' ... it does belittle the lived experience of those who daily encounter the challenges and benefits of being visibly different - be this in everyday interactions with their own parents, or with others who ask 'where are you from', or in the process of 'passing' or in more material encounters with bureaucratic procedures in relation to rights.

- Kirsten McGavin and Farida Fozdar. ${ }^{1}$

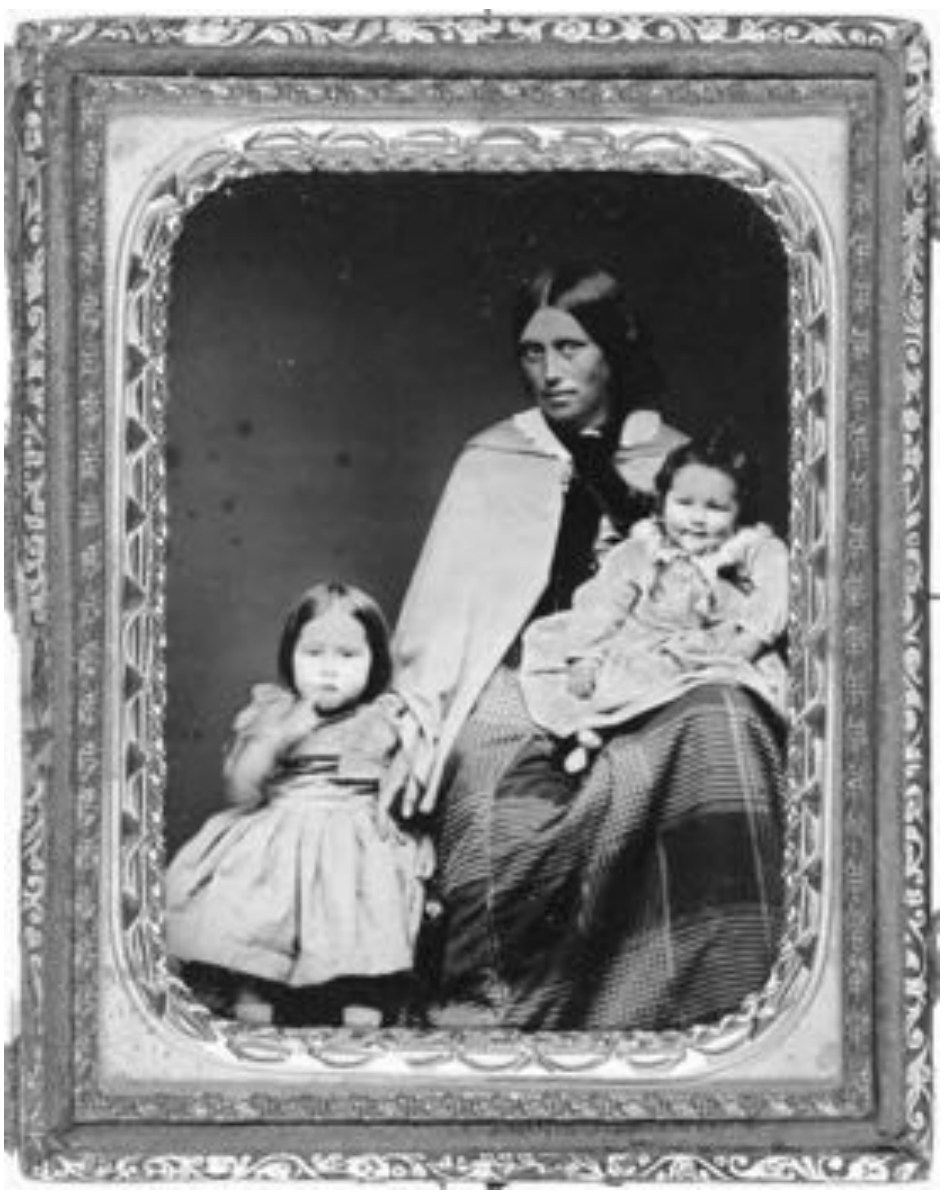

Figure 7. Jane Maria Gray with her children. Ref: 1/2-137188-F. Alexander Turnbull Library, Wellington, New Zealand. /records/23010883.

\footnotetext{
${ }^{1}$ Kirsten McGavin and Farida Fozdar, "Mixed Race' in the Australo-Pacific Region' in Kirsten McGavin and Farida Fozdar (eds.), Mixed Race Identities in Australia, New Zealand and the Pacific Islands, (New York: Routledge, 2017), p. 2.
} 


\section{Introduction}

Until I started university, the only New Zealand history I had learnt in schools had been from the Treaty of Waitangi in 1840 onwards. Of course, things happened before that, but it felt as though what really mattered was how Pākehā came to New Zealand, modernized Māori, and made New Zealand in the image of Britain. This chapter considers this Pākehā invented 'encounter narrative' between themselves and Māori and how it influenced enumeration legislation, legal administration, and the expression of mixed-race identity.

A current gap exists in more recent enumeration data where mixed-race Māori are willing to identify themselves in the census as being descended from Māori. However, this identification does not extend to ethnically identifying as Māori. This gap between descent and identity underpins this chapter as enumeration, until very recently, actively worked to condense identity. Yet again, this shows how mixed-race Māori were place in a precarious position of both privilege and challenge, which will be elucidated below. As stated in the introduction chapter, not all Māori identify as mixed-race and this chapter does not look to diagnose a reason for this. Rather, the gap between descent and identity will be explored with the intention to trace the gradual, reluctant, allowance of freedom to self-identify in the law.

How did this identification variance come to be? What does immigration, the acceptance of others, and blood quantum have to do with it? Although socially, politically and legally constructed, questions about race and ethnicity have lived consequences that are very real respecting the hierarchical treatment of people. How populations are counted matters as much as which populations are counted. This is because enumerators can construct a narrative with their data resulting in the canon of the country's population history being at their whim.

\section{The 'New Zealander' Question}

The issue with an historical New Zealand census is that it was often not an objective empirical piece of evidence, it was a tool for erasure for particular groups. ${ }^{2}$ On March 7, 2006 it was my 10th birthday and I filled out my New Zealand census form with the help of my mother. While it was the third census of my lifetime, it was the first that I remembered. In this census of Population and Dwellings there was 'the ethnicity question' which caused a public and media buzz regarding "the format of the question and the purpose of the statistics." 3 This questioning led to

\footnotetext{
${ }^{2}$ Issues concerning Māori exclusion and the census are still fraught in 2019 from the 2018 census: see 'Maori Have Been Let Down by Census Botch-Up", Stuff, 15 August 2019; accessed 26 August 2019.

${ }^{3}$ Statistics New Zealand, Final Report of a Review of The Official Ethnicity Statistical Standard 2009, (Wellington: New Zealand Government, 2009), p. iii.
} 
unprecedent number of the population responding that they were ethnically a "New Zealander."4

It is understandable for there to be a fundamental misunderstanding of the purpose of the ethnicity question regarding how the results influence the terms of funding and prioritization of support from the government. It is also understandable that there exists a fundamental misunderstanding of the implication made when one asserts that they are a "New Zealander." This is because there is little clarity on what defines a 'New Zealander.' Statistics New Zealand's 'Final Report of a Review of the Official Ethnicity Statistical Standard' in 2009 explained that "a persistent challenge has been accommodating people of European ancestry, whose ethnic identity has evolved with the increasing proportion of this population living in New Zealand for two or more generations." 5

A profile report from the 2006 Census results explained that the "New Zealander" category "was welcomed by people who felt uncomfortable with the problematic terms New Zealand European and Pākehā, and who may have seen New Zealander as a more appropriate way of describing themselves." So, does this make it a category for those uncomfortable with being called Pākehā? Therefore, is 'New Zealander' synonymous with Pākehā? The 2006 report stated that "many of those in the New Zealander category reported having Māori descent than Māori ethnicity...12,876 people indicated they belonged to the Māori ethnic group, while 41,820 reported having Māori descent." The numbers and report would suggest that to be a "New Zealander" is to either be uncomfortable in being defined as Pākehā /New Zealand European, or, to have Māori ancestry but cultural behaviours that are consistent with Pākehā because, "well we're all mixed, aren't we."7

On the other hand, what if we define "New Zealander" as someone with Māori descent but who no longer identifies as being "culturally" indigenous, simply descended from an ethnic/immigrant grouping? The term can be more accommodating to use for mixed-race Māori if you are mixed-race Māori but do not look or act as a such. The 2009 report on how the census considered ethnicity in 2006 noted the problematic nature of the response "New Zealander" stating "it is ambiguous, because it can refer to either an ethnic identity or the national identity of all

4 ibid, p. 1.

5 ibid.

${ }^{6}$ Statistics New Zealand, Profile of New Zealander Responses, Ethnicity Question: 2006 Census, (Wellington: New Zealand Government, 2007), p. 11.

${ }^{7}$ Kirsten McGavin and Farida Fozdar, “Mixed Race' in the Australo-Pacific Region’, p. 2. 
citizens of this country." ${ }^{\prime \prime}$ In 1853, Governor George Grey referred to the Māori population as "New Zealanders." In 1859, writer Arthur S Thomson also referred to Maori as "New Zealanders." 10 This label had been used to described Māori since James Cook arrived in 1769. Its employment in the 2006 census saw that a noun which was once applied to Māori, was now being deployed to make Māori invisible.

In the 2009 report on the 2006 census, the Department of Statistics noted what respondents and members of the public thought "New Zealander" meant. Responses described a modern set of requirements for someone to have access to the term. These included "birthplace and tenure" and "if their family had lived in New Zealand for five, six, or seven generations." 11 The term triggered strong opinion regarding its importance:

[Some] thought that 'New Zealander' was an alternative response for 'New Zealand European', and a similar number thought people of mixed ethnic groups would call themselves 'New Zealanders', with one respondent thinking it might be for Māori that are 'half-caste' and another for first generation 'New Zealanders'... Others added a caveat of being born here but not of Māori descent, or, not Māori or Pākehā. Others thought it applied to newer migrants to New Zealand, or to people who didn't like to use the term Pākehā or who would rather identify with 'New Zealander' than with their ethnicity. ${ }^{12}$

Statistics New Zealand knew that officially introducing "New Zealander" as an option could cause upset as "recent migrants could see it as a test of their loyalty, and indigenous Māori and other settled groups could consider it an unjustified use of a label that applies equally to them, but not in ethnicity terms ['New Zealander'] raises issues about citizenship and sovereignty."13 Pākehā and mixed-race identifying Māori are both seemingly inclined towards the term. They are also two groups (the former more so than the latter) where "this genealogy of empathetic racial

\footnotetext{
${ }^{8}$ Statistics New Zealand, Final Report of a Review of The Official Ethnicity Statistical Standard 2009, p. 12.

${ }^{9}$ George Grey, Ko Nga Moteatea, Me Nga Hakirara O Nga Maori, (Wellington: The Honorable Robert Stokes, 1853), p. VIII.

${ }^{10}$ Arthur S. Thomson, The Story of New Zealand: Past and Present - Savage and Civilized, Volume 2, (London: John Murray, 1859), p. 69.

${ }^{11}$ Statistics New Zealand, Final Report of a Review of The Official Ethnicity Statistical Standard 2009, pp. 39-40.

12 ibid.

13 ibid, p. 13.
} 
impersonation has often meant power, privilege, and stereotype." ${ }^{14}$ This is as the 'New Zealander' category's intent to wholly encompass such groups and not to differentiate effectively erases the different lived experiences of Māori and mixed-race Māori and Europeans.

This attempt "teaches us about the process and hazards of racialization, and the naïve but sincere search for cross-racial understanding." 15 This is the base point of this chapter's consideration of how the census interpreted Māori and how this has impacted mixed-race identity. The data from c.1850-1950 enumeration allows for a look at how the legal administrative tools of the census have evolved. Throughout the research and writing of this chapter, it became clear that the overwhelming response to the "New Zealander" question in 2006 was more understandable than first thought.

\section{Where Did the Popularity of The Encounter Narrative Come From?}

What allowed for Europeans to create a 'White' New Zealand ancestry which created a gap between descentism and ethnic identification for mixed-race Māori was propagating Māori as the superior 'inferior' race and that this superiority was transitory until complete assimilation. The monopolizing encounter narrative focusing on interactions and relations between Māori and Pākehā that was spread to potential emigrants in the British Isles backfired. Emigrants upon their eventual New Zealand settlement noticed that they had been misled in how harmonious the narrative was. ${ }^{16}$ Many second and third wave British settlers made complaints against the New Zealand Company's deceitful interpretation of land attainment and the "competing Māori and European claims to the land...it was argued that the Company, in its haste to populate its territory, had pocketed emigrants' money without making proper surveys of the land." 17 To quell the concerns of the new settlers, and to defuse their accusations of being misled, evidence was needed to show "superior natives, and the superior treatment of natives." 18 This was one of the main differentiating factors in which New Zealand was advertised to the world "and told the difference between Australian Britons and New Zealand ones."19

Established settlers were not interested in showing the 'superior treatment' to Māori which

\footnotetext{
${ }^{14}$ Alisha Gaines, Black for a Day: White Fantasies of Race and Empathy, (Chapel Hill: University of North Carolina Press, 2017), p. 171.

15 ibid.

${ }^{16}$ Marjory Harper, 'A Century of Scottish Emigration to New Zealand', Historical Studies in Ethnicity, Migration and Diaspora, Vol. 29, no. 2, 2011, pp. 232-233.

17 ibid.

${ }^{18}$ James Belich, 'Myth, Race and Identity in New Zealand', New Zealand Journal of History, Vol. 31, no. 1, 1997, p. 19.

19 ibid.
} 
was propagated overseas. Many were opposed to Māori voting in elections as they saw enfranchisement as something that "was a trust rather than a right...[Māori] were unfit to undertake such an important obligation by virtue of their ignorance of political matters, inability to understand English, questionable loyalty to the Crown, and susceptibility to corruption." 20 Māori men who owned land under crown title were able to vote from 1852, however, few were able to due to the Crown title requirement. ${ }^{21}$ This was owing to what Pākehā called the "peculiar" way Māori held land, being communal. ${ }^{22}$ However, growing tensions in the height of the Wars saw some Pākehā politicians argue for Māori representation. This included James FitzGerald, Minister of Native Affairs, who recognised that though Māori men were able to vote under the 1852 provisions, a temporary initiative was needed until all Māori land became Crown title and more Māori men could vote. ${ }^{23}$ The 1867 Māori Representation Act introduced four seats for Māori representation in the House of Representatives. ${ }^{24}$ The 1867 Act allowed Māori men over the age of 21 to vote in elections, and stand for parliament, regardless of whether they owned Crown titled land. ${ }^{25}$ The caveat was having to vote and stand for the Māori electorates only. The few Māori men who were eligible to vote in 1852 retained their ability to vote in European electorates, but they could now also vote in the Māori electorate (until 1893 when dual voting was abolished). ${ }^{26}$

What of mixed-race Māori and their position in this new Māori electorate system? As an example, I will use politician James Carroll (1857-1926). Carroll's father was Sydneyborn Irishman, Joseph Carroll and mother, Tapuke, was descended from Ngāti Kahungunu. ${ }^{27}$ After Carroll's death in 1926, he was described by Ngāti Kahungunu author, Tiaki Hikawera Mitira, in 1944;

Never was Maori and pakeha blood fused to better purpose... One has written, "Does it not seem strange to us that the son of an Irish father and a Maori mother, should all his life have been proud to think of himself as a Maori, and all his life have acted as a European." If it was this mingled ancestry that made him great, it was his insistence on his

\footnotetext{
${ }^{20}$ Neill Atkinson, Adventures in Democracy: A History of the Vote in New Zealand, (Dunedin: University of Otago Press, 2003), p. 46.

${ }^{21}$ New Zealand Constitution Act 1852.

22 Maori Representation Act 1867.

${ }^{23}$ Neill Atkinson, Adventures in Democracy: A History of the Vote in New Zealand, p. 49.

${ }^{24}$ Maori Representation Act 1867.

25 ibid.

${ }^{26}$ Electoral Act 1893.

27 Tiaki Hikawera Mitira, Takitimu, 2nd ed. (Wellington: Reed Publishing, 1972), p. 207.
} 
Maori blood that sealed his greatness. He was acceptable to both races. The story of the period of transition which faced the Maori people in their gradual conversion to pakeha ways of life, might have contained many more sad tales of misunderstandings and heartburnings had he not lived. ${ }^{28}$

Mitira's mentioned acceptance in Pākehā and Māori communities was not entirely accurate. Carroll's political career can be described as trying to use a Pākehā system to help Māori. In 1883, Carroll successfully defeated Wi Pere in 1887 for the Eastern Maori Seat. ${ }^{29}$ However, in 1893 Carroll successfully stood for election in the Waiapu Electorate, a European seat. ${ }^{30}$ Carroll was able to do this as the 1893 Electoral Act stipulated that Māori owning Crown titled land or "any male or female half-caste" had the right to "choose to enrol in general (European) electorates, provided they gave up their right to vote in the Maori seats." 31

Carroll believed Māori would see more tangible change if they were to vote in the European electorates. ${ }^{32}$ Whether he used his 'half caste' status to stand for the European seat, or owned Crown titled land, or both, the move from a Māori electorate to a Pākehā one alienated some Māori. This was due to a climate where "an unprecedented degree of [pan] Maori unity" was seen from the "Kotahitanga movement." 33 Beginning in 1892, the movement held an annual "Maori parliament" until 1902, its purpose, in brief, showed "typical Maori capacity for adaption [as] it took on the contours and procedures of 'pakeha parliament." 34 In addition to Māori backlash, Carroll could also not fully appease Pākehā in this social climate where, despite Carroll not speaking on Māori issues to Pākehā audiences, some Pākehā saw his European seat win as “returning a 'fifth Maori Member' to the House" when Māori were only allocated four seats. ${ }^{35}$ James Carroll illustrates how someone who comes from both can receive backlash from both for not meeting the groups specific racial needs. This is despite the rhetoric of mixed-race 'fusions' having greater acceptance in New Zealand and 'harmonious' race relations being propagated through the British Empire.

\footnotetext{
28 ibid.

29 ibid, p. 210.

30 ibid.

${ }^{31}$ Neill Atkinson, Adventures in Democracy: A History of the Vote in New Zealand, p. 95.

32 ibid, p. 100.

${ }^{33}$ Richard Hill, State Authority, Indigenous Autonomy: Crown-Maori Relations in New Zealand/Aotearoa 1900-1950, (Wellington: Victoria University Press, 2004), pp. 38-39.

34 ibid.

${ }^{35}$ Neill Atkinson, Adventures in Democracy: A History of the Vote in New Zealand, p. 100.
} 
Perceptions of Māori and the idea of them as a similar race with shared Aryan (IndoEuropean) origins mattered. ${ }^{36}$ This was because it made Māori inclusion in Pākehā spaces appear more justified as the theory was founded in pseudo-ethnography. Though the term was later popularized in Europe in the 1930s by Nazism and a "utopian vision of genetics", the idea that Māori were Aryan was sporadically popular between the mid to late nineteenth century (with remnants moving into the twentieth century). ${ }^{37}$ The theory was that Māori migration patterns were only traceable by "European scholarship" and that tracing back intermarriage throughout the Asian continent led to their origin being near the Persian Gulf. ${ }^{38}$ James Belich usefully argues that Pākehā racial opinion in the nineteenth century was "more Aryanist than white" and that Aryanism was more "flexible" in that it covered "Scots, Welsh and Irish" but excluded Southern and Eastern Europeans. ${ }^{39}$ Though this ideology was not accepted by all, "it was widespread" and enduring. ${ }^{40}$

Examples of legislation which show this enduring 'Aryan' ideology are the 1881 Chinese Immigrants Act, 1882 Imbecile Passengers Act, the 1898 Kauri Gum Industry Act and Richard Seddon's attempt at passing the blatantly racist Asiatic Restriction Bill 1896. All were examples of the prevention of 'aliens' (usually Asian, excluding the Indian Empire). These concerns would persist and would be taken up by some Māori leaders like Āpirana Ngata and Peter Buck. Greg Ryan states that due to Ngata and Buck both being mixed-race the two saw themselves as most suited and "uniquely qualified to understand and analyse Maori culture and to articulate it to a new generation of [white] anthropologists... [this] manifested in continuing restrictive immigration policies against the Chinese in particular."41 If Aryan theory allowed for Māori and Pākehā to share common ground, this was something that Māori leaders wanted to protect and preserve so there would be greater leverage to elevate Māori in a Pākehā society. Unfortunately, this elevation manifested itself in exclusionary support of legislation and legal administration towards other minorities and saw the solidification of the Māori-Pākehā encounter narrative. It is important to note that though Ngata acknowledged and used the fact he was mixed, he self-identified as Māori. ${ }^{42}$ MPK Sorrenson argued that Ngata "had no sympathy for the long-held Pakeha assumption that he,

\footnotetext{
36 The "Indo-Aryan Diaspora Myth" connected to Māori origins was never "universally" accepted "but it was widespread" for more see: James Belich, 'Myth, Race and Identity in New Zealand', New Zealand Journal of History, Vol. 31, no. 1, 1997, p. 17.

${ }^{37}$ Paul Moon, Encounters: The Creation of New Zealand, (Auckland: Penguin Books, 2013), pp. 112-113, 325.

38 ibid, pp. 112-113.

${ }^{39}$ James Belich, 'Myth, Race and Identity in New Zealand', p. 20.

40 ibid, p. 18.

${ }^{41}$ Greg Ryan, 'Anthropological Football', New Zealand Journal of History, Vol. 34, no. 1, 2000, p. 66.

42 M.P.K Sorrenson (ed.), Na To Hoa Aroha: From Your Dear Friend: The Correspondence Between Sir Apirana Ngata and Sir Peter Buck, 1925-50, Volume 1: 1925-29, (Auckland: Auckland University Press, 1986), p. 15.
} 
Buck, and other leaders of the Young Maori Party owed their success to their Pakeha 'blood'... Ngata said many times, he owed his success to the determination of his kin...to support him in his quest for Pakeha knowledge so that it could be adapted to the needs of Ngatiporou."43

In 1907, the Wellington Branch of the 'Anti-Asiatic League' appeared with paternalistic sentiments towards Māori and European women which manifested itself as an ugly, racist organization attempting and advocating for the prevention of Chinese and other 'Alien' men employing or marrying Māori and European women. ${ }^{44}$ Māori/Asian employment relations were partly a consequence of the exclusion of Māori from unemployment relief benefits during the depression and Chinese market gardeners being willing to employ Māori men and women and provide food and accommodation. ${ }^{45}$ The 1926 Census saw that fears of Māori/Chinese unions were being realized in that the number of children from such relationships were increasing compared to earlier enumeration results. ${ }^{46}$ When asked about the children of Māori women and Chinese men, Āpirana Ngata stated in 1929 that "The further question of the relations between Maori girls and the Asiatics is one that I must mention without being able to offer any solution. The Akarana Maori Association has suggested a prohibition... but there are the laws of nature, and I do not know how we are going to prohibit the action of these." 47

It is important to note that these fears were only voiced by the loud and large parts of society, dissenters were present. One unnamed dissenter stated in a 1907 letter to the editor for the Evening Post that there is "no cause for the white man to fear the yellow man. He does not invade the labour market to the ousting of the white man. He pays his way and keeps out of the clutches of the law. The records of the Magistrate's Court show that the white man is prominent there. I doubt if there is a Chinaman in any of the gaols of the chief cities of the colony." ${ }^{48}$ So what does the fear of 'others' tell us about mixed-race identity in terms of New Zealand enumeration and immigration? It shows that fear comes from an insecurity of self. The monopolization narrative in New Zealand of the Māori/European mixed offspring being a symbol of the re-unification of two good, 'Aryan' races and harmonious race relations was threatened by other racial mixes, where rather than celebrating multi-ethnic societies, fear was propagated.

\footnotetext{
43 ibid.

${ }^{44}$ Angela Wanhalla, Matters of the Heart, (Auckland: Auckland University Press, 2013), p. 135.

45 Joanna Boileau, Chinese Market Gardening in Australia and New Zealand: Gardens of Prosperity, (Switzerland: Palgrave Macmillan, 2017), pp. 249-250.

46 Statistics New Zealand, The New Zealand Official Year-Book, 1929, (Wellington: New Zealand Government, 1929).

${ }^{47}$ Apirana Ngata, NZPD, 1929, Vol. 221, p. 487.

48 'Anti-Asiatics League', Evening Post, 18 May 1907, p. 9.
} 


\section{The First 'National' Census}

Prior to 1851 there were multiple enumeration divisions working where information was usually collected from regions of the country with no national, standardized system. An example of an enumeration division was the 'Blue Books' which sporadically included Māori. ${ }^{49}$ 'Blue Books' were statistical compilations created by the Crown Colony government which were used between 1840-52. The Governor of New Zealand had to send the 'Blue Books' to the British government, these contained various population statistics including legislation, occupations, education and crime data. ${ }^{50}$ The Census Ordinance of 1851 saw the introduction of a national system of population enumeration for Pākehā. It ordered that a "census of the number and condition of the population of the Islands of New Zealand" be introduced and conducted every three years but this count excluded Māori. ${ }^{51}$

The NZLC discussions on the ordinance show a theme of not wishing to include Māori, and actively working to find a legitimate reason to exclude Māori. In May 1849 the NZLC were trying to work out how to keep the costs down for the proposed general census. Edward Eyre, the Lieutenant-Governor of New Munster, when asked if "Natives" would be included stated, "certainly not." 52 Upon elaboration, Eyre said that it was necessary for enumerators to be able to speak te reo. Eyre added that the reluctance of "the most civilized natives" to give information requested in previous regional enumeration was due to a lack of English comprehension. ${ }^{53}$ Eyre did state that "the native Secretary and Interpreter might be employed for this purpose" in the future. ${ }^{54}$ Māori, according to Eyre, would decelerate the process of enumeration and would cost more money, as the native Secretary and Interpreter would need to be employed for this task..$^{55}$

The cost of the census was seemingly less of an issue where Pākehā were concerned. Henry Seymour told the NZLC of a "plan" which "had suggested itself to him which would lessen the expense....every [Pākehā] house holder with whom a schedule was left, should, on a certain day, deliver the same to the Resident Magistrate or some other officer." shot down because Pākehā settlers were already "inclined to question the propriety of the census at all, and it would certainly be more objectionable if house-holders were required to travel two or

49 'A History of Census Taking in New Zealand', Statistics New Zealand Archive Site, 2013; accessed 25 June 2019.

50 ibid.

${ }^{51}$ An Ordinance for Taking a Census of the Colony of New Zealand, 15 July 1851, s. 1.

52 'Legislative Council', New Zealand Spectator and Cook's Strait Guardian, 19 May 1849, p. 2.

53 ibid.

54 ibid.

${ }^{55} \mathrm{Ibid}$.

56 ibid. 
three miles to deliver the return." ${ }^{57}$ More money was willing to be spent to ensure Pākehā involvement in the census, this included the ease of returns. Such allowances were unthinkable to give to Māori.

According to the NZLC Māori were not worth the effort to enumerate. They made Pākehā work and spend money on their language and their knowledge. Upon further discussion of why Māori should be excluded from being included in the census, John Greenwood stated that:

[Greenwood] had some printed forms sent to him on one occasion at Nelson for collecting the Maori census, he tried it one day with the assistance of an interpreter but found it so troublesome that he was obliged to give it up. One Maori gave the names of himself and his family, and having returned some 200 pigs, proceeded to give the names of the pigs. ${ }^{58}$

There was very little thoughtful discussion for why Māori may not have been so willing to open to enumerators. It was generally accepted at face value by the NZLC that the language barrier was reason enough. However, Māori had a knowledge base that worked "seamlessly" throughout their whānau, hapū and iwi networks it is these networks where Māori were comfortable sharing their information. ${ }^{59}$ What this Māori knowledge base shows is that "social capital is created through networks and relationships that are within all of these expressions of "family" or community...in the Māori context, the distinction between cultural and social capital disappears." ${ }^{60}$ More than just a language difference, Pākehā were unwilling to incorporate the "expression of cultural capital in practice" which Māori based their "ways of operating" on. ${ }^{61}$

\section{'Living Like a Māori'}

Statistics New Zealand state that "the first census to count (rather than estimate) the total Maori population" was between 1857 and 1858. ${ }^{62}$ Ian Pool agrees calling the 1857-58 census enumerated by Francis Fenton, Chief Judge of the Native Land Court, the first of "the more

\footnotetext{
57 ibid.

58 ibid.

${ }^{59}$ David Robinson, 'Social Capital and Voluntary Activity: Giving and Sharing in Māori and Non-Māori Society', Social Policy Journal of New Zealand, Vol. 17, December 2001, p. 55

${ }^{60}$ David Robinson, 'Social Capital and Voluntary Activity: Giving and Sharing in Māori and Non-Māori Society', p. 55.

61 ibid

62 'Census Timeline 1840-1859', Statistics New Zealand Archive Site, edited 25 March 2013; accessed 25 June 2019.
} 
systematic censuses." 63 A nationwide census for Māori, similar to the 1851 European census, was not introduced until $1874 .{ }^{64} \mathrm{~A}$ contributing factor to the call for wariness when concerning inaccuracy is the definition of 'Maori.' The 1881 definition of Maori in the census was "Maori and half castes living as Maori." ${ }^{\prime 65}$ By 1896, the definition for Maori added another category of those "who are 'living as European." "66 What is of note is that "the reverse did not apply to Pākehā living 'as Māori." "67 These definitions were at the discretion of the enumerators and consequently decided how a 'half-caste' would be ethnically grouped depending on how an enumerator thought 'living like a Māori’ looked like. ${ }^{6}$

Māori did not welcome this alien form of population research and management with open arms. This fact is as important as the statistics from Māori who did supply data for the census in the nineteenth century. Māori who were against completing the Māori census were populated near areas where much land was lost, although antagonism could be seen in all areas of the country towards the exercise. ${ }^{69}$ Some factors contributing dislike of the enumeration included the fear of poll tax, the fear of payment being wanted, the fear of conscription and even "extermination, or for deportation once it was known who had survived contact with Pākehā."70 By the turn of the century the main point to emphasize regarding enumeration in the case of many Māori was that the choice of self-identification was not given at all. Angela Wanhalla stated that:

In 1891 Māori of mixed ancestry in Otago were, the enumerator decided, not 'living as members of a Maori tribe' and were omitted from the Māori census and instead included in the general one. In the same year, 40 'half-castes' in Auckland were excluded from George Wilkinson's return for the Māori census as they 'occupy wooden houses, and to all intents and purposes live like Europeans'. With the

\footnotetext{
${ }^{63}$ Ian Pool, Te Iwi Maori: A New Zealand Population Past, Present and Projected, (Auckland: Auckland University Press, 1991), p. 31.

${ }^{64}$ Lachy Paterson, 'Hāwhekaihe: Māori Voice on the Position of 'Half-Castes' within Māori Society', Journal of New Zealand Studies, Vol. 9, March 2010, p. 136.

${ }^{65}$ Neriko Musha Doerr, 'Beyond 'Mixed Race' and 'Unmixed Race', Being and Having Race in Aotearoa/New Zealand' in Kirsten McGavin and Farida Fozdar (eds.), Mixed Race Identities in Australia, New Zealand and the Pacific Islands (New York: Routledge, 2017), p. 219.

66 ibid.

${ }^{67}$ Damon Salesa, 'Half-Castes Between the Wars: Colonial Categories in New Zealand and Samoa', New Zealand Journal of History, Vol. 34, no. 1, 2000, p. 106.

68 ibid.

${ }^{69}$ Kate Riddell, 'Improving' the Maori: Counting the Ideology of Intermarriage', The New Zealand Journal of History, Vol. 34, no. 1, 2000, pp. 94-96.

70 ibid, p. 96.
} 
tick of a box, people who may have culturally identified as Māori were enumerated in the general census as 'half-castes living as Europeans', generating the data politicians needed to demonstrate the material effects of assimilation in action. ${ }^{71}$

This can be viewed as a form assimilation and colonisation through imposing added identity. This form of assimilation "escapes being viewed as pathological because assimilated individuals are perceived to be privileged with Pākehā beliefs, values, practices, and norms and are aligned with whiteness/racial superiority and privilege."72

The census enumerators perceived that mixed-race Māori who were 'living as Europeans' were privileged. This perception, from agents of the State, eventually reaches citizens and for mixed-race Māori, becomes a self-occupied and assured privilege. Mixed race people can accept the supposed 'gift' of Europeanness that has been placed upon them and eventually "assimilated Māori may reject their iwi connections by denying their genealogy."73 This is a very important point and arguably it was not until in the 1980s that some felt more comfortable reclaiming their genealogy the reason for which will be covered later in this chapter. This goes for not only those mixed-race Māori who reject their whakapapa, but also those "who do not fit either a traditional or assimilated articulation of identity." 74 These individuals are thus considered "identityless/rootless and are pathologized as colonized." 75

\section{The Census Between 1900-1950: Improper Fractions}

During the early twentieth century the census was not concerned with how one identified personally, the impetus was placed on the fractions that made up a citizen's heritage being as 'accurate' as possible. Despite mixed-race Māori such as Carroll claiming both sides of his heritage, overall "it would not have fitted assimilation theories for Māori to be part-Pākehā and yet consider themselves Māori." ${ }^{\prime 76}$ As is the fluid nature of identity, mixed race people would be transient in their choices. Though the census was to measure how the European/Māori mix could show the positives of intermarriage through assimilation, mixed race people were more likely to

\footnotetext{
${ }^{71}$ Angela Wanhalla, Matters of the Heart, p. 128.

72 Tess Moeke-Maxwell, 'Bi/Multiracial Maori Women's Hybridity in Aotearoa/New Zealand', Discourses: Studies in the Cultural Politics of Education, Vol. 26, no. 4, 2005, p. 502.

73 ibid.

74 ibid.

75 ibid.

${ }^{76}$ Kate Riddell, 'Improving' the Maori: Counting the Ideology of Intermarriage', p. 92.
} 
consider themselves Māori. ${ }^{77}$ How you accept yourself and how others accept you is delicate and changes and transforms into different machinations over time. However, "biological descent is either present or absent... presence of descent does not mean the someone will always identity as Indigenous." ${ }^{\prime 78}$ Descent, no matter how much, is non-negotiable but the choice of accepting it comes down to an individual consenting to how they wish to identify. Descent means nothing without choice, you cannot have one without the other.

The census was a State attempt to measure descent through fractions and blood arithmetic, but in doing so it removed the choice of self-identification. The opposite is also true, a person could not choose to identify as being descended from Māori, even if they identify with or even as Māori. Just as white people can use performative blackness in the USA, "if a person of color felt an instinctive or spiritual connection to whiteness, that feeling would never fully guarantee the protection of white privilege."79 This shows the nuances of the subject and the redundancy of trying to empirically understand a multifaceted thing like race which has layers of descent, physiognomy, culture.

By 1900, the enumeration data collected on Māori was still not as detailed as the data collected of and for Europeans. ${ }^{80}$ However, by Māori, I mean those who enumerators defined as such. By 1916 there was a population of 49,776 enumerator-identified-Māori, but only 1900 enumerator-identified-Māori were South Island residents. ${ }^{81}$ This was because, in order to save money on conducting a separate Māori census, South Island Māori were given the same schedules and enumerators as Pākehā. ${ }^{82}$ Its justification was that "the few distinctly Maori settlements in the South island were all in close proximity to European settlements, and very few of the South Island Maoris [were] incapable of speaking and reading English." 83 The North Island continued to have the two systems, one general and one for enumerator-identified-Māori. Whiteness equated to Europeanness. In losing the choice to identify as Māori, South Island Māori had their proximity to whiteness protected. Mixed-race superiority was thus re-iterated and the gap between descent and identity widened. In 1929 Āpirana Ngata stated in parliament that:

\footnotetext{
77 ibid, p. 93.

78 Emma, 'Descent, Classification and Indigeneity in Australia', in Kirsten McGavin and Farida Fozdar (eds.), Mixed Race Identities in Australia, New Zealand and the Pacific Islands, (New York: Routledge, 2017), p. 21.

${ }^{79}$ Alisha Gaines, Black for a Day: White Fantasies of Race and Empathy, p. 170.

${ }^{80}$ Statistics New Zealand, Statistical Publications 1840-2000, (Wellington: New Zealand Government, 2004$)$, p. 46.

${ }^{81}$ Statistics New Zealand, Report on the Results of a Census of the Population of the Dominion of New Zealand Taken for the Night of the 15 ${ }^{\text {th }}$ October 1916, (Wellington: Census and Statistics Office, 1920).

82 ibid.

83 ibid.
} 
As one went further south, one was better satisfied [of the present generation of Maori], because in the South Island the Europeanising process has been carried on a little more rapidly than in the North. That would appear to be so far as physical type is concerned. Though a large proportion are half-caste, and midway between half-caste and full European, still, in their outlook and spirit and physical characteristics they are very much Maori. Those of us who are interested in the Maori race would deplore less the loss of physical type then the loss of what may be called the Maori spirit. It pervades the Maori of the South Island just as much as it does his kindred of the North. ${ }^{84}$

However, other Māori leaders wondered how long this 'Māori spirit' would be left intact. In Peter Buck's letter to Ngata in 1928, Buck stated from his residence in Hawaii that:

The Hawaiians remind me strongly of the South Island Ngaitahu. The infiltration of the whites has broken up their village system so that they live as families in a European or rather American community. There is not a single native built house in the whole of Hawaii. Their setting is entirely American. They have gone a stage further than the Ngaitahu. The Ngaitahu can still gather together and have a Maori welcome and tangi. At the Hawaiian home we visited, there were over a hundred guests most with a dash of Hawaiian blood. ${ }^{85}$

In 1912, Native Minister James Carroll said on the topic of Māori children from European relations that "Māori were not yet convinced of the benefits of being 'improved' by amalgamation with Pākehā." 86 In 1921, the Census showed the Māori population were increasing for various reasons. Government statisticians thought that these included interracial offspring, improved sanitary education, the Māori Health Department giving Māori more resources to fight off illness, and a "greater desire to be industrious than was the case some years ago." ${ }^{77}$ Pākehā were happy to be thanked for all of this. Māori were not a dying race, they were present and active members of

\footnotetext{
${ }^{84}$ Apirana Ngata, NZPD, 1929, Vol. 221, p. 488.

85 M.P.K Sorrenson (ed.), Na To Hoa Aroha: From Your Dear Friend: The Correspondence Between Sir Apirana Ngata and Sir Peter Buck, 1925-50, Volume 1: 1925-29, p. 151.

${ }^{86}$ Kate Riddell, 'Improving' the Maori: Counting the Ideology of Intermarriage', p. 91.

87 'Census of the Maori Population', AJHR, Session 1, H-39a, 1921, p. 2.
} 
New Zealand society, they were however "becoming whiter." 88 Once again, the law (being the census) was being influenced by Pākehā society seeing what they wanted to see "a reflection of common nineteenth-century (mostly Pākehā) ideology, rather than an expression of how Māori viewed themselves." 89

Through the census, Pākehā were able to compile a set of data that showed the results that they wanted to publish to validate their opinions and actions. In a report on the 1921 Māori census, there were two categories of Māori as opposed to the intense fractions of the past, these categories were "full-blood" and "half-blood." 90 By 1921, it is not unlikely that enumerators defined "halfblood" by having distinguishably different parents but "colour does not always equate neatly with culture." 91 This showed how enumerators saw "the presence or absence of brownness or whiteness act as a cultural marker." 92 To say that Māori were doing better because of Pākehā, when Pākehā were the cause of grievances towards Māori is overtly manipulating data to ignore what has happened in society. In this instance, 'half-castes' could be used as tools for propaganda regarding assimilation through the census. Though happy to be congratulated for Māori numbers growing exponentially, behind closed doors "the numbers involved were not insignificant and were enough to create problems for the analysis of Māori population trends." 93

From the 1926 census onwards, the consensus from results was that though attempts to calculate 'half-castes' were continually made, mixed-race people proved not to be static in definition. This was especially seen when what Ian Pool calls "category-jumping" was involved. ${ }^{94}$ The 1926 census "gave a strict technical meaning to half-caste, knowing well that in general usage it was applied loosely to anyone who had mixed blood." 95 Māori were enumerated in 1926 under the criteria that if your 'blood' was "half or more" you would be enumerated as Māori. ${ }^{96}$ This definition is of course different to the previous Māori census. This is because the criterion of being "half-caste" and "living as European" in 1921 caused "the intercensal Maori growth rate from that date until 1926 [to become] unbelievably high, 21 per cent, whereas when the definitions are more directly comparable, the rate is only 12 percent, which is high but not unacceptably so."97 The idea

\footnotetext{
${ }^{88}$ Damon Salesa, 'Half-Castes Between the Wars: Colonial Categories in New Zealand and Samoa', p. 107.

${ }^{89}$ Kate Riddell, 'Improving' the Maori: Counting the Ideology of Intermarriage', p. 91.

90 'Census of the Maori Population', AJHR, Session 1, H-39a, 1921, p. 7.

${ }^{91}$ Tess Moeke-Maxwell, 'Bi/Multiracial Maori Women’s Hybridity in Aotearoa/New Zealand', p. 505.

92 ibid.

${ }^{93}$ Ian Pool, Te Iwi Maori: A New Zealand Population Past, Present and Projected, p. 18.

94 ibid.

95 Damon Salesa, 'Half-Castes Between the Wars: Colonial Categories in New Zealand and Samoa', p. 106.

96 ibid.

${ }^{97}$ Ian Pool, Te Iwi Maori: A New Zealand Population Past, Present and Projected, p. 18.
} 
of imposing a category by using pseudo-science, such as blood quantum, in an appearance of showing greater accuracy proved to have lasting consequences.

This change for greater precision led to greater obsession with the 'blood' make up of a mixed-race person once more. However, the excuse of wanting, as Pool states, "more directly comparable" data, is flimsy. ${ }^{98}$ The reintroduction of recording up to an eighth of someone's heritage was only required for mixed-race Māori. This intense detail was not required of other racial mixes who were Māori and a non-British race. Pool calls this exclusion as one of the "minor illogicalities" the 1926 census had. ${ }^{99}$ However, an alternate reading suggests that the categorization "had more to do with the interest in Māori assimilation, physical or cultural, than with interest in finding out the racial composition of all New Zealand residents." 100

Due to the Depression and World War Two there was only one census between 1926 and 1945 which took place in $1936 .{ }^{101}$ The 1946 census was brought forward to 1945 where the general census was held for the twentieth time. 1945 also marked the end of the separate Māori census which was held for the fifteenth time. ${ }^{102}$ The first half of the twentieth century allows for an insight into how legal administration attempted to take pictures of the mixed-race population over a period of time, through the census, to support their interests or confirm their fears. It also allows for an insight into how these pictures continue to influence mixed-race people, as Angela Wanhalla states "census statistics rarely make visible the complexities of cross-cultural relationships, how cultural traditions are maintained, how customs are mixed into new forms, how people live together, and the emotional contours and patterns of everyday life." 103

\section{Case Study: The Blue Book}

The Blue Book is South Island iwi Ngāi Tahu's index of lineage. It usefully shows how Māori can use census type material for their own ends. The Blue Book was prepared by the Ngai Tahu Census Committee in the 1920s whose intentions were to compile a list of all Ngāi Tahu who were alive in 1848 to establish its legitimate beneficiaries. ${ }^{104}$ The prospect of a financial settlement with the Crown was the immediate prompt for what was, essentially, a retrospective 1848 census of Ngāi Tahu. In 2001, Hana O’Regan stated the accuracy of the Blue Book could be

\footnotetext{
98 ibid.

99 ibid.

100 Neriko Musha Doerr, 'Beyond 'Mixed Race' and 'Unmixed Race', Being and Having Race in Aotearoa/New Zealand', p. 217.

101 'Census Timeline 1900-1949’, Statistics New Zealand Archive Site, edited 25 March 2013; accessed 25 June 2019.

102 'Census Timeline 1900-1949', Statistics New Zealand Archive Site, edited 25 March 2013; accessed 25 June 2019.

${ }^{103}$ Angela Wanhalla, Matters of the Heart, p. 139.

${ }^{104}$ Hana O’Regan, Ko Tahu, Ko Au: Käi Tahu Tribal Identity, (Wellington: Horomaka Publishing, 2001), p. 53.
} 
supported due to only one addition being made since its publication. ${ }^{105}$ In the current document on Ngāi Tahu's website, there have been five additions to the Ngāi Tahu Kaumatua list since 1929. 106 In 2000, members of Ngāi Tahu got together for a hui regarding their vision for Ngāi Tahu over the next 25 years. One of the goals they wished to have completed within five years of the hui was: "The completion of the whakapapa database based on the 1848 census (the Blue Book) [which] enabled all Ngāi Tahu Whanui to identify with at least one Papatipu Runanga... This database will identify the Papatipu Runanga linkages to each of the 1848 kaumatua."107

Working alongside a master file detailing the "huge and systematic whakapapa" of Ngāi Tahu, O'Regan argues that the iwi "are extremely fortunate to have had this resource available, as it has relieved a lot of the pressures place upon the collective to define "who we are." 108 I found this really interesting as it made clear the distinctions between iwi today are a direct result of what happened in the past. Namely, the clinical approach to enumeration through what was applied to Ngāi Tahu historically, is applied to themselves, by themselves, today.

Throughout the nineteenth century the census was resisted, engaged with, and sometimes accommodated by indigenous peoples in settler societies. Indeed, the census was not merely just an act of counting people. ...Ngāi Tahu leaders drew a link between land loss and counting, and sought to redefine the enumeration process, by establishing a 'census' that has become the basis for tribal membership, participation and identity today. ${ }^{109}$

By 1966, the Maori Purposes Act saw that when there was a question as to whether someone was a descendant of Ngāi Tahu and therefore a beneficiary, the Ngai Tahu Maori Trust Board had to first determine whether someone's claim to the iwi was legitimate. ${ }^{110}$ A claimant had to be able to trace their familial connection back to Ngāi Tahu kaumātua in the Blue Book. ${ }^{111}$ The

\footnotetext{
105 ibid.

106 'Ngai Tahu Kaumatua Alive in the 1841 as established by the Maori Land Court in 1925 and the Ngai Tahu Census Committee in 1929', Issued by Ngai Tahu Maori Trust Board as at $1^{\text {st }}$ January 1967, (reprinted $1^{\text {st }}$ January 2002).

107 'Ngāi Tahu 2025: Presented at Vision 2025 at a Hui-ä-Tau held at Kaikōura in 2000', Ngāi Tahu Iwi Website, accessed 2 June 2019, p 14. URL: https://ngaitahu.iwi.nz/wp-content/uploads/2013/06/NgaiTahu_20251.pdf

${ }^{108}$ Hana O’Regan, Ko Tahu, Ko Au: Kāi Tahu Tribal Identity, p. 53.

${ }_{109}$ Angela Wanhalla, 'The Politics of 'Periodical Counting': Race, Place and identity in Southern New Zealand', in Tracey Banivanua Mar and Penelope Edmonds (eds.), Making Settler Colonial Space, (London: Palgrave Macmillan, 2010), p. 198.

${ }^{110}$ Maori Purposes Act 1966.

111 'Ngai Tahu Kaumatua Alive in the 1841 as established by the Maori Land Court in 1925 and the Ngai Tahu Census Committee in 1929', Issued by Ngai Tahu Maori Trust Board as at $1^{\text {st }}$ January 1967, (reprinted $1^{\text {st }}$ January 2002 ).
} 
Board had the jurisdiction to reject a claim of descent and if it did, within six months of the rejection the decision could be appealed through the Maori Land Court, however, once the Court had made their decision it was "final and conclusive." 112 In making secondary the importance of culture and physiognomy, O'Regan argues this heightens the "primacy of a tribal identity over a general Māori identity." 113 Even in terms of whāngai where a child is raised within the iwi, but their biological heritage is not to Ngāi Tahu, without whakapapa the child's inclusion "could only ever be a temporary state; the permanence inherent in whakapapa was something that could not be acquired or given away." "114 If you cannot prove your descent to the Blue Book, you cannot receive resources that the rest of the iwi do, regardless of how you identify. Tony Ballantyne illustrates how this type of legal administration has a lasting influence:

The new bodies of demographic, ethnographic, and historical knowledge produced by agents of empire ultimately textualized cultures and subsequently transformed the mentalities and social practices of colonized, indigenous, and enslaved populations, who increasingly understood their own communities through the categories of caste, tribe, religion, and race that were elevated and calcified under colonial rule. ${ }^{115}$

This vigilance in terms of whakapapa is connected to the reparations from settlements that need to be protected to safeguard them for descendants of Ngāi Tahu in the future. The issue of whakapapa becomes important to prove when Pākehā "are confronted with the possibility that an individual's Māori ethnicity might result in some form of economic gain." ${ }^{116}$ In Pākehā eyes, if you are not physically Māori you need to prove you are Māori. There seems to be a pervasive fear that some Māori might receive benefits to which they are not entitled.

Years of enumeration based on blood quantum has shaped Pākehā opinion on identity being inextricable from blood. Māori identity does not fit comfortably in a European legal and capitalist economic model. Pākehā opinion, alongside Pākehā legal and economic models influence Māori identity and this can be seen in the importance of whakapapa through the Blue Book to Ngāi Tahu.

\footnotetext{
112 ibid.

113 Hana O’Regan, Ko Tahu, Ko Au: Käi Tahu Tribal Identity, p. 55.

114 ibid, pp. 55-57.

115 Tony Ballantyne, 'Paper, Pen, and Print: The Transformation of the Kai Tahu Knowledge Order', Comparative Studies in Society and History, Vol. 3, no. 2, 2011, p. 233.

${ }^{116}$ Hana O'Regan, Ko Tahu, Ko Au: Kāi Tahu Tribal Identity, p. 133.
} 
You need to both choose to identify as Ngāi Tahu, but you also need to be able to prove your whakapapa to Ngāi Tahu through the Blue Book. When it comes to monetary reparations how you identify is not enough. That is the economics behind Māori identity. O’Regan believes that Ngāi Tahu are fortunate for the Blue Book as "many other tribes are presently struggling with the problems of identifying their members, especially in the light of having to manage and organize post-Treaty settlement situations." 117 The importance of the Blue Book to Ngāi Tahu speaks to the individual iwi experience of collective identity, they have long been considered 'white' Maori, or no longer Maori, or a subsection of indigenous legitimacy. ${ }^{118}$ This also speaks to the difference between South Island and North Island Māori experiences. The table following is from the Te Arawa Lakes Trust Website, the Trust is an administrator formed from the Te Arawa Lakes Settlement Act 2006. ${ }^{119}$ To be a settlement beneficiary requires one to be descended from any TeArawa hapu that is listed in the 2006 Act, who in 1840 exercised customary rights over one of the Te Arawa lakes. ${ }^{120}$ Such descendants only need to prove the last three generations in their heritage.

Angela Wanhalla has stated of her Ngāi Tahu iwi that "census taking provided evidence for the erasure of Ngāi Tahu land ownership and territorial rights, while enumerators also reconstructed the tribal population as 'white."'121 However, Ngāi Tahu used enumeration practice for their own purposes, namely, to take back what was taken away. Whakapapa to Ngāi Tahu is seemingly more than family history. It is an affirmation of identity. O'Regan calls it that "untouchable, steadfast element" to their identity. ${ }^{122}$ Just because something is written does not make it true, however, to be counted as Māori in this document is for one to be defined as Māori for themselves and their descendants for the rest of time.

\footnotetext{
117 ibid, p. 53.

118 ibid, p. 122.

119 Te Arawa Lakes Settlement Act 2006, s. 12(2).

120 ibid.

${ }^{121}$ Angela Wanhalla, 'The Politics of 'Periodical Counting': Race, Place and identity in Southern New Zealand', p. 198.

${ }^{122}$ Hana O’Regan, Ko Tahu, Ko Au: Käi Tahu Tribal Identity, p. 54.
} 


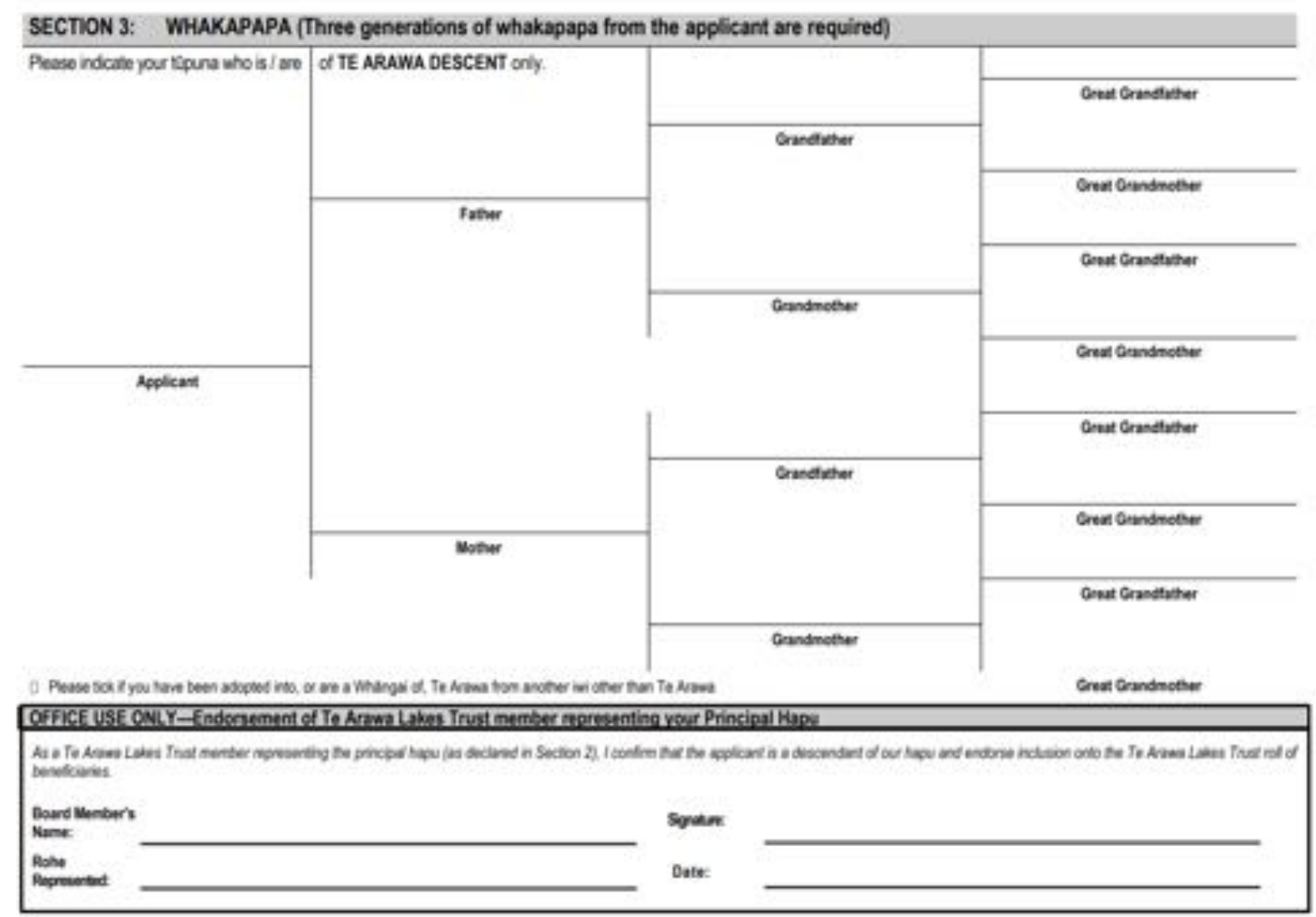

Figure 8. Te Arawa Iwi Registration Form as at 2019 from Te Arawa Lakes Trust: https://tearawa.iwi.nz/; accessed 1 July 2019.

\section{Back to the Future, 1950- Today:}

Mass Māori urbanization saw Pākehā and Māori in closer contact than ever before. In the 1960s the Department of Maori Affairs undertook a detailed inventory on Māoridom including aspirations, policies and resources. ${ }^{123}$ This alternative enumerative action was for more information on urbanization issues, "the state to finally redress the problems arising from the relentless fragmentation of ownership of interests in Maori land", and for the Government to relinquish to Māori some sovereignty in decision making to do with them. ${ }^{124} \mathrm{With}$ this climate, the Hunn report was released to the public in 1961. ${ }^{125}$ The surveying gathered statistical information on the exhaustive facets of Māori daily life such as education, occupations as well as crime and health. ${ }^{126}$ A simplistic summary of the report is that Māori could work and improve with

123 Richard Hill, Maori and the State: Crown Relations in New Zealand/Aotearoa 1950-2000, (Wellington: Victoria University Press, 2009), p. 89.

124 ibid.

125 Jack Kent Hunn, Report on Department of Maori Affairs: With Statistical Supplement, 24 August 1960, (Wellington: Government Printer, 1961).

126 ibid. 
what they had left, rather than losing more assets. This way "they would both better integrate into Pakeha society and contribute to the general prosperity of the nation." ${ }^{27}$ Richard Hill stated on the Report that:

The Hunn report has been demonised in recent years, but generally for anachronistic reasons. Critics have tended to condemn its lack of interest in Maori autonomy. It is unrealistic, however, to expect official analyses and recommendations made in 1960 to have encompassed rangatiratanga. Any such review would naturally fall within the constrained parameters of the received wisdom of officials and politicians concerned, for whatever reasons, to improve the socio-economic lot of Maori. ${ }^{128}$

I am reluctant to agree that such criticism is 'anachronistic.' I say this because arguing that Māori autonomy was unlikely to come from the mouth of the State in the 1960s suggests that no one was making the State aware of such aspirations for autonomy at the time. You cannot overarchingly say they were doing their best and are just representative products of their time when there were vocal, powerful people who contemporarily dissented. This is seen in Āpirana Ngata's correspondence with Peter Buck from 1932 where Ngata noted that "the strictures of the Pakeha have hardened the determination and fighting spirit of our people." ${ }^{129}$ Māori, from the outset and well into the twentieth century, resisted assimilation.

When the Labour Party won the 1972 election Matiu Rata was appointed Minister of Lands and Minister of Maori and Pacific Island Affairs. Rata made extensive changes for Māori during his time in parliament. ${ }^{130}$ Of note was the 1973 Maori Affairs Amendment Bill which would be the beginning of closing the gap between identity and descent. ${ }^{131}$ Rata changed what defined a Māori, finally ending the era of official blood quantum and moving to any amount of descent from an ancestor. This was very significant as legislation prior had often reduced Māori identity to fractions. Rata also amended electoral law so than anyone defined as Māori now had "the opportunity to exercise their electoral option" by choosing the Māori or general roll. ${ }^{132}$ By 1991, the census saw self-identification be reiterated through a maximum of three ethnic groups, although a marked step

\footnotetext{
127 Richard Hill, Maori and the State: Crown Relations in New Zealand/Aotearoa 1950-2000,p. 89.

128 ibid.

129 M.P.K Sorrenson (ed.), Na To Hoa Aroha: From Your Dear Friend: The Correspondence Between Sir Apirana Ngata and Sir Peter Buck, 1925-50, Volume 3: 1932-50, (Auckland: Auckland University Press, 1989), p. 78.

${ }^{130}$ Maori Affairs Amendment Bill 1973.

131 ibid.

132 Neill Atkinson, Adventures in Democracy: A History of the Vote in New Zealand, pp. 197-198.
} 
forward "people who described themselves as belonging to one, two or three ethnic categories, one of which is 'New Zealand Maori"' were placed in the New Zealand Māori cohort regardless of the other options ticked. ${ }^{133}$

The introduction in 2006 of the 'New Zealander' option seems less unreasonable. To pander to the idea of a progressive multi-ethnic society, the option staunchly signified that there was no longer any need for consideration of ethnicity because everyone in New Zealand was 'the same'. In an attempt to treat everyone the same, once again, the erasure of the various lived Māori experiences took place. This is because a legal administrative tool such as a census can act as a vanity project that "pointed to erasures upon many indigenous populations in former colonies through law and violence" and validated colonial superiority. ${ }^{134}$ The freedom to self-identify along with the discussions of not "looking" Māori enough in the following oral interview section show that the simple act of counting has had vast implications to mixed-race identity.

\section{Oral Interviews}

Vanessa stated in her interview that at her high school in Whakatane she looked white compared to the other students and she had a European surname. This caused an identity complex which shows how cultural identity "belongs to the future as much as to the past." 135 Vanessa said, "I always had to prove my 'Māoriness'... I felt like you had to prove the percentage ... [due to] growing up white I'm always like ok, do I come across as a European or do I come across as a Māori?"'136

Rhianna informed me that during her childhood and early teen years she primarily identified as Pākehā. "That's what my Mum would write down, she would tick New Zealand European for my ethnicity on my school thing and then she would put like Māori as second if she had to."137 Rhianna explained that this caused some confusion with her identity as a child. Rihanna knew that she was Māori because she was brown, and her father was brown, but she did not know what this meant for her in terms of self-identity.

Similarly, when talking about university enrolment forms, Jordan, stated that she would tick herself as New Zealand European. 'I don't know, it's just kind of how I've been brought up and I'm not super Māori or super anything else. I'm very just white [refers using hand gestures to her skin

\footnotetext{
133 Statistics New Zealand, The Official Yearbook 1996, (Wellington: New Zealand Government, 1996).

${ }^{134}$ Angela Wanhalla, 'The Politics of 'Periodical Counting': Race, Place and Identity in Southern New Zealand' p. 198.

${ }^{135}$ Stuart Hall, 'Cultural Identity and Diaspora' in Jonathan Rutherford (ed.), Identity: Community, Culture, Difference, (London: Lawrence \& Wishart, 1990), p. 225

136 Vanessa Immink interview conducted by Kiriana Haze, 12 April 2019, Wellington, New Zealand.

${ }^{137}$ Rhianna Morar interview conducted by Kiriana Haze, 1 May 2019, Wellington, New Zealand.
} 
colour], but if they wanted to know, like if it was a survey, asking for what I am then I would tick all the boxes that I would be." ${ }^{138}$ Both Rhianna and Jordan show how a gap between identity and descent can be constructed. They also show how society bases identity on skin colour.

Matthew explained that his brother "refuses to allow [Matthew's] nephews to be enrolled as Māori or Pacifica on a school roll because he doesn't want them to be used as statistics, he's real anti it." "139 Matthew elaborated that he could see where his brother was coming from in terms of negative stereotyping. How someone perceives themselves to be is influenced by the world around them and "identifying with a low status group may result in low-self-regard."140 Avoiding this is understandable but also shows how "threats to Māori identity have been numerous."141

\section{Conclusion}

In Pākehā forging a New Zealand ancestral identity for themselves, a divide and conquer strategy played out through enumeration and immigration. The gap between descent and ethnicity that this chapter opened with matters. The gap matters because in recent years it has, against all odds, been getting smaller through the reclamation of identity. The constructed narrative nineteenth and early twentieth century enumerators told did not win. You are always a consequence of something in terms of statistics and empirical understandings. The documentation of a country and its inhabitants is important and necessary. However, the questions asked, and the results presented, are coloured by the shades of society that are not easily distinguishable from numbers alone. Though race is a construct, the action of documenting it makes it something very real. When you identify as Māori alongside any other category you identify with, you are rejecting the notion of blood quantum gatekeeping, you are rejecting the notion of an imposed identity. Kate Riddell states that "in contrast to nineteenth - and early twentieth - century predictions, intermarriage has added directly to the numbers of those people who choose to define themselves as Maori and of Maori descent."142 The statement is reaffirmed in what my interviewees told me, they are defying assimilation predictions from the nineteenth and early twentieth century by acknowledging the duality in their experience rather than isolation. They are defining themselves by not conflating privilege with a lack authenticity, but by acknowledging privilege and accepting the individual experience as authentic.

\footnotetext{
138 Jordan Bougen interview conducted by Kiriana Haze, 13 October 2017, Upper Hutt, New Zealand.

139 Matthew Lambert interview conducted by Kiriana Haze, 22 May 2019, Upper Hutt, New Zealand.

140 J.S. Phinney, 'Ethnic Identity in Adolescences and Adults: Review of Research', Psychological Bulletin, Vol. 108, no. 3, 1990, p. 501 .

${ }^{141}$ T Moeke-Pickering, Maori Identity Within Whanau: A Review of Literature, Working Paper, University of Waikato, New Zealand, 1996, p. 4.

${ }^{142}$ Kate Riddell, 'Improving' the Maori: Counting the Ideology of Intermarriage', p. 97.
} 
As we own these 'faults' in authenticity they no longer become faults, they become an essential part of our being. 


\section{Chapter Five: Conclusion}

Nah, it's racist as fuck. I mean, I think New Zealand is the best place on the planet, but it's a racist place... They're like, 'Oh, you've done so well, haven't you? For how you grew up. For one of your people.'

-Taika Waititi. ${ }^{1}$

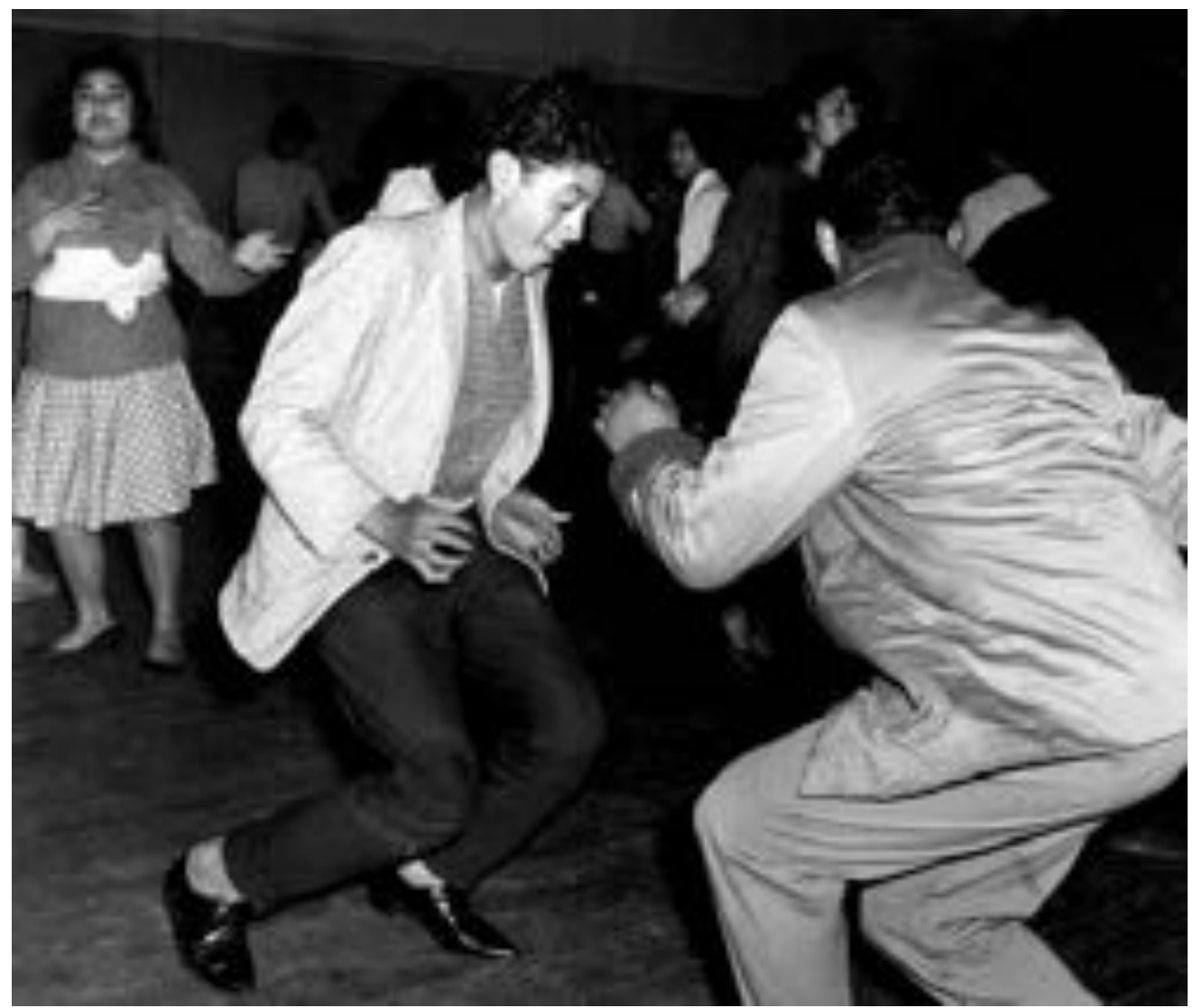

Figure 9. Auckland Māori Community Centre, 1960s: Photograph by Ans Westra. Ref: AAMK W3495/28H. Archives New Zealand - Te Rua Mahara o te Kāwanatanga.

\footnotetext{
${ }^{1}$ Alex Denney, 'Unknown Mortal Orchestra \& Taika Waititi on New Zealand Culture', Dazed, 5 April 2018;
} accessed 26 July 2019. 


\section{Conclusion}

Before embarking on this project, I would mention that I was interested in mixed-race Māori identity research. The most common response I would receive was that there was already extensive literature on Ngāi Tahu, by Ngāi Tahu, but I had not even mentioned Ngāi Tahu. The narrative and resources available on mixed-race Māori from Ngāi Tahu scholars are important. However, over 200 years after first Pākehā/Māori contact, the narrative has shifted in New Zealand. Interracial relationships happened all over the country and no one iwi has a monopoly of that experience.

'Half-caste' is a colonial term used to divide Māori. This term is very readily seen in legislation and legal administration between c.1850-1950. What I have shown in this thesis is that some Māori (such as 'half-castes'), by virtue of lighter skin and fractions of ancestry, were defined or treated as Europeans. Whether mixed-race Māori were conscious of it or not, it was a legal and social advantage to be considered as such. This work has shown that a legal identity is not a personal identity. But, what a legal identity can do is powerful. It can impose a reimagined version of a personal identity. Consequently, who you need to be to look after yourself, to survive in a colonial landscape (both historically and now), necessitates the fluidity of identity. Despite some advantages, there were also the legal and social disadvantages mixedrace Māori faced. They were infantilised, paternalised and dehumanised and it is important to remember that though they were 'above' Māori, they were also below Pākehā and faced much of the worst parts of colonisation as 'full' Māori did.

This thesis' main substantive chapters were ordered as 'Marriage and Land', 'Native Schools', and finally 'Enumeration.' You are born, if you are lucky you get educated, then you become an adult who gets counted as a member of society. 'Marriage and Land' as a chapter argued that the children of interracial marriages were used to help create a 'new', New Zealand racial hierarchy in the law. The children had amalgamation tactics thrust upon them. This chapter showed that 'illegitimate' interracial marriages and 'illegitimate' interracial children were a very real legal issue in New Zealand which greatly impacted land dealings. Such laws had consequences for mixed-race children, which were a reminder that if your parents did not 'match', the law needed to reconcile you with Pākehā ideals of identity. However, this reconciliation process had limits and Māori resisted it in order to re-affirm identity on Māori terms. These terms included the understanding that mixed-race is a reality; it is not something you are constantly conscious of. It is a different way to express and relate to people.

The 'Native Schools' chapter identified that the disparities in Māori educational achievement today resulted from years of control, submission, and alienation through Māori schooling. The experiences of mixed-race children in the education system, past and present, 
matter. The paradoxical inclusion and exclusion of mixed-race children led to opportunities that were undermined by caveats. From their inception, Native Schools were informed by the idea of 'civilising' through English language pedagogy for reading, writing, arithmetic, and of course, worshiping God. Mixed-race Māori students were often given preferential treatment compared to their Māori peers, but they also faced the same disregard of their language and culture and were perceived as a threat, a potential criminal underclass. This is history, but these were children who were made to feel as though their culture and language was an offense and their worth was cheap. Mixed-race children did not face the worst parts of the Native Schools system, but they were not immune to it either.

The 'Enumeration' chapter argued that as it is so easy for mixed-race Māori to feel they need to be Pākehā or Māori, it is important to remember that this feeling was not accidental. This feeling has been imposed for over two centuries with very little official affirmation that it is acceptable to identify as both. The settings where mixed-race Māori are made to feel different (where they look or act 'too' Māori or 'too' Pākehā), add up to moments of vulnerability. This is partly because 'blood quantum usage', historically a preoccupation of officials, is still used colloquially today. Māori culture and physiognomy are still used as precursors to identity today. The census has a lot to answer for concerning the gap between choosing to tick that you descend from Māori versus identifying as Māori. This chapter critiques the enumeration practices that have occurred in New Zealand which placed mixed-race Māori in a position of privilege and challenge. It also showed that a census, which takes so little time to complete, can have extremely long lasting consequences. This can be seen even now, with the fallout from the 2018 census. In this census Māori were, once more, let down and excluded with the introduction of online data collection which led to "the absence of reliable Māori data [which] has been described as an impediment on [Māori] self-determination and progress that will have an impact for up to a decade." 2 Despite the state of enumeration in New Zealand today, the chapter did end on a hopeful note, that defying earlier predictions of Māori extinction through enumeration would continue.

Barack Obama, the 44th President of the United States, was brought up when I was first discussing this project with one of my supervisors. Obama was the 'first black president', but this discussion was about how he was 'light skin black.' The media during his first campaign were obsessed and fascinated that he had a white mum and a black dad. It was not that such a child had never been born before; it was that this preoccupation both helped and hindered how

\footnotetext{
2 'Maori Have Been Let Down by Census Botch-Up", Stuff, 15 August 2019; accessed 26 August 2019.
} 
palatable he was to USA voters. Obama eloquently wrote about this universal, mixed-race, outsider/insider bind:

When people who don't know me well, black or white, discover my background (and it is usually a discovery, for I ceased to advertise my mother's race at the age of twelve or thirteen, when I began to suspect that by doing so I was ingratiating myself to whites), I see the splitsecond adjustments they have to make, the searching of my eyes for some tell-tale sign. They no longer know who I am. Privately, they guess at my troubled heart, I suppose - the mixed blood, the divided soul, the ghostly image of the tragic mulatto trapped between two worlds. And if I were to explain that no, the tragedy is not mine alone, it is yours, sons and daughters of Plymouth Rock and Ellis Island, it is yours, children of Africa, it is the tragedy of both my wife's six-yearold cousin and his white first grade classmates, so that you need not guess at what troubles me, it's on the nightly news for all to see, and that if we could acknowledge at least that much then the tragic cycle begins to break down...well, I suspect that I sound incurably naive, wedded to lost hopes, like those Communists who peddle their newspapers on the fringes of various college towns. Or worse, I sound like I'm trying to hide from myself. ${ }^{3}$

This is not to compare myself to the $44^{\text {th }}$ President of the United States, but I am also constantly aware that in asserting myself as 'white' feels both 'ingratiating' and somewhat sycophantic. Unlike Obama (and there are many possible allusions to this difference: race, age, gender, country, family background, wealth), I always attempted to ingratiate myself as Pākehā until I realised that I was resisting the wrong thing. I thought that I was resisting all the negative stereotypes of being Māori without realising all the good I was cutting out too. The act of acknowledging an origin that is both Pākehā and Māori shows a refusal to accept complete colonisation.

This refusal is not easy, and it is constant, because implicitly, this work has been about control. How much control is granted to someone over their own identity, which was seen in all the interviews I conducted for this thesis. For too long, Māori have been denied, not only the label they choose, but the terms of that label and what they define as the meaning of it. The

\footnotetext{
${ }^{3}$ Barack Obama, Dreams from My Father Second Edition, (Melbourne: Text Publishing Melbourne Australia, 2009), p. Xv.
} 
racialised position of a person is emotional as much as it is physical. What I know to be true is that I have never fitted in anywhere, like my interviewees. I have never been comfortable in any setting because I reflect my own complex identity qualifiers into any given situation, like my interviewees. I over-analyse how those around me see me in terms of race, like my interviewees. I am not the first to feel this way, I am not alone in feeling this way, and I will not be the last.

I cannot sufficiently stress the emotion that was in the interviews I conducted. The embarrassment and the shame and the sadness that my interviewees carried over the belief they did not know enough. The fear that they would never know or be allowed to know enough because of having to be a part of two worlds that do not easily or readily co-exist. This emotion was raw, and it was real and the term 'half-caste' and its use in the law cannot and should not be considered in only historical terms. Legislation and legal administration affected social identity in New Zealand through the creation of a social structure that suited Pākehā. This structure has been maintained or changed in the law by Pākehā. What this work has ultimately established is that the law was used by Pākehā to make themselves gatekeepers of access to Māori identity. This thesis has dealt with the history of this gatekeeping, but the effects continue to be felt. 


\section{Bibliography}

\section{Primary Sources (Official)}

Acts and Ordinances:

An Ordinance for the Support of Destitute Families and Illegitimate Children, 26 October 1846. An Ordinance for Promoting the Education of Youth in the Colony of New Zealand, 7 October 1847.

An Ordinance for Taking a Census of the Colony of New Zealand, 15 July 1851.

Education Act 1877.

Electoral Act 1893.

Half-Caste Disability Removal Act 1860.

Maori Affairs Amendment Act 1974.

Maori Purposes Act 1951.

Maori Purposes Act 1966.

Maori Representation Act 1867.

Marriage Act 1854.

Middle Island Half-Caste Crown Grants Act 1877.

Middle Island Half-Caste Grants Act 1883.

Middle Island Half-Caste Grants Act 1885.

Middle Island Half-Caste Grants Act 1888.

Native Land Act 1909.

Native Schools Act 1858.

Native Schools Act 1867.

Native Land Amendment Act 1912.

Native Land Court Act 1894.

New Zealand Constitution Act 1852.

Stewart Island Grants Act 1873.

Te Arawa Lakes Settlement Act 2006.

Appendices to the Journal of the House of Representatives (AJHR):

'Report of the State of Native Affairs in New Zealand', AJHR, Session 1, 9 July 1856.

'Reports on Native Schools', AJHR, Session 1, E-1, 16 June 1858.

'Papers Relative to Native Education: Being Reports of Inspectors of Native Schools', AJHR, Session 1, E-8, 23 August 1860.

'Native Schools: Reports of Inspectors Presented to Both Houses of The General Assembly Pursuant to Act $21 \& 22$ VIC. C. 55', AJHR, Session 1, E-9, 1863.

'Petition of Wi Te Hakiro and 336 Others', AJHR, Session 1, J-4, 29 June 1876.

'Half-Caste Claims in the South and Stewart Island', AJHR, Session 1, G-9, 12 July 1876.

'The Native Schools Code', AJHR, Session 1, H-1, 4 June 1880.

'Report on Middle Island Native Land Question', AJHR, Session 1, G-1, 1 January 1888.

'Middle Island Half-Caste Grants', AJHR, Session 1, G-8, 23 July 1890.

'Education in Native Schools', AJHR, Session 1, E-2, 1899.

'Education in Native Schools', AJHR, Session 1, E-2, 1908.

'Education in Native Schools', AJHR, Session 2, E-3, 1909.

'Native-Land Claims Commission', AJHR, Session 1, G-5, 1 January 1921.

'Census of the Maori Population', AJHR, Session 1, H-39a, 1921.

'Education of Native Children, AJHR, Session 1, E-3, 1939. 


\section{Parliamentary Debates:}

NZPD, 1858-60.

NZPD, 1861-63.

NZPD, 1867, Vol. 1(2).

NZPD, 1877, Vol. 26.

NZPD, 1885, Vol. 52.

NZPD, 1882, Vol. 43.

NZPD, 1897, Vol. 99.

NZPD, 1900, Vol. 115.

NZPD, 1903, Vol. 127.

NZPD, 1910, Vol. 150.

NZPD, 1910, Vol. 152.

NZPD, 1911, Vol. 156.

NZPD, 1929, Vol. 221.

NZPD, 1938, Vol. 253.

NZPD, 1951, Vol. 296.

\section{Law Reports:}

Rira Peti v Ngaraihi Te Paku (1888) 7, New Zealand Law Reports (NZLR), pp. 235-241.

\section{Miscellaneous Primary:}

Education Review Office/Te Tari Arotake Matauranga, Promoting Success for Māori Students:

Schools' Progress, June 2010, (Wellington: New Zealand Government, 2010).

Grey, George, Journals of Two Expeditions of Discovery in North-West and Western Australia, During the Years 1837, 38, and 39, (London: T and W Boone, 1841).

Grey, George, Ko Nga Moteatea, Me Nga Hakirara O Nga Maori, (Wellington: The Honorable Robert Stokes, 1853).

Hunn, Jack Kent, Report on Department of Maori Affairs: With Statistical Supplement, 24 August 1960, (Wellington: Government Printer, 1961).

New Zealand Educational Institute, Report and Recommendations on Maori Education Presented to 1967 Annual Meeting, (Wellington: New Zealand Educational Institute, G. Deslandes Ltd., 1967).

'Ngai Tahu Kaumatua Alive in the 1841 as established by the Maori Land Court in 1925 and the Ngai Tahu Census Committee in 1929', Issued by Ngai Tahu Maori Trust Board as at $1^{\text {st }}$ January 1967, (reprinted $1^{\text {st }}$ January 2002).

'Ngāi Tahu 2025: Presented at Vision 2025 at a Hui-ā-Tau held at Kaikōura in 2000', Ngāi Tahu Iwi Website, accessed 2 June 2019, pp. 1-50. URL: https://ngaitahu.iwi.nz/wp-content/uploads/2013/06/NgaiTahu_20251.pdf

Rusden, George William (ed.), Aureretanga: Groans of the Maoris, (London: William Ridgway, 1888). 
Statistics New Zealand, Report on the Results of a Census of the Population of the Dominion of New Zealand Taken for the Night of the 15 th October 1916, (Wellington: Census and Statistics Office, 1920).

Statistics New Zealand, Final Report of a Review of The Official Ethnicity Statistical Standard 2009, (Wellington: New Zealand Government, 2009).

Statistics New Zealand, Profile of New Zealander Responses, Ethnicity Question: 2006 Census, (Wellington: New Zealand Government, 2007).

Statistics New Zealand, Statistical Publications 1840-2000, (Wellington: New Zealand Government, 2004).

Statistics New Zealand, The New Zealand Official Year-Book, 1929, (Wellington: New Zealand Government, 1929).

Statistics New Zealand, The Official Yearbook 1996, (Wellington: New Zealand Government, 1996).

Tai Tokerau District Maori Land Development Scheme Register, c. 1961, Series 24179, Box 5, Record R23419177, Archives New Zealand, Auckland.

Taylor, Richard, The Past and Present of New Zealand; With its Prospects for the Future. With Numerous Illustrations, (London and New Zealand: William Macintosh and Henry Ireson Jones, 1868).

The Teaching of English in Native Schools: The Direct, Or Natural, Method, (Wellington: Education Department, 1917).

\section{Primary Sources (Unofficial)}

Newspaper Articles:

Daily Southern Cross

Evening Post

Nelson Examiner and New Zealand Chronicle

New Zealand Spectator and Cook's Strait Guardian

New Zealander

Poverty Bay Herald

The Press

Taranaki Herald

\section{Interviews:}

Chelsey Aroha Brown interview conducted by Kiriana Haze, 21 June 2017, Wanuiomata, New Zealand.

Jordan Bougen interview conducted by Kiriana Haze, 13 October 2017, Upper Hutt, New Zealand.

Maddison Baker interview conducted by Kiriana Haze, 14 March 2019, Wellington, New Zealand.

Matthew Lambert interview conducted by Kiriana Haze, 22 May 2019, Upper Hutt, New Zealand.

Rhianna Morar interview conducted by Kiriana Haze, 1 May 2019, Wellington, New Zealand. 
Vanessa Immink interview conducted by Kiriana Haze, 12 April 2019, Wellington, New Zealand.

\section{Secondary Sources}

\section{Books:}

Alexander, R.R., The Story of Te Aute College, (Wellington: A.H. \& A.W. Reed, 1951).

Anderson, Atholl, The Welcome of Strangers: An Ethnohistory of Southern Māori, (Dunedin: Otago University Press, 1998).

Anderson, Atholl, Race Against Time: The Early Māori-Pākehā Families and the Development of the Mixed-Race Population in Southern New Zealand, (Dunedin: Otago University Press, 1991).

Anderson, Atholl, Judith Binney, Aroha Harris, Tangata Whenua: A History, (Wellington: Bridget Williams Books, 2015).

Atkinson, Neill, Adventures in Democracy: A History of the Vote in New Zealand, (Dunedin: University of Otago Press, 2003).

Ballantyne, Tony, Webs of Empire: Locating New Zealand's Colonial Past, (Vancouver: UBC Press, 2014).

Barbee, Winifred, Coming Aware of Our Multiraciality: The Politics of Skin Color, (Colorado: Outskirts Press, 2006).

Barrington, J.M and T.H. Beaglehole, Maori Schools in a Changing Society, (Wellington: New Zealand Council for Education Research, 1974).

Barrington, John, Separate but Equal? Māori Schools and the Crown 1867-1969, (Wellington: Victoria University Press, 2008).

Barrington, John, Maori and the State: Crown-Māori Relations in New Zealand/Aotearoa, 1950-2000, (Wellington: Victoria University Press, 2009).

Belich, James, 'Myth, Race and Identity in New Zealand', New Zealand Journal of History, Vol. 31, no. 1, 1997, pp. 9-22.

Binney, Judith, Stories Without End: Essays 1975-2010, (Wellington: Bridget Williams Books, 2010).

Bird, Stephanie Rose, Light, Bright, and Damned Near White: Biracial and Triracial Culture in America, (Santa Barbara: Greenwood Publishing Group, 2009).

Boileau, Joanna, Chinese Market Gardening in Australia and New Zealand: Gardens of Prosperity, (Switzerland: Palgrave Macmillan, 2017).

Gabriel, Deborah, Layers of Blackness: Colourism in the African Diaspora, (London: Imani Media, 2007).

Gaines, Alisha, Black for a Day: White Fantasies of Race and Empathy, (Chapel Hill: University of North Carolina Press, 2017). 
Glenn, Evelyn Nakano (ed.), Shades of Difference: Why Skin Color Matters, (Stanford: Stanford University Press, 2009).

Hall, Ronald E (ed.), The Melanin Millennium: Skin Color as 21st Century International Discourse, (Dordrecht: Springer, 2013).

Harris, Aroha, Hīkoi: Forty Years of Māori Protest, (Wellington: Huia Publishers, 2004).

Hill, Richard, State Authority, Indigenous Autonomy: Crown-Maori Relations in New Zealand/Aotearoa 1900-1950, (Wellington: Victoria University Press, 2004).

Hill, Richard, Maori and the State: Crown Relations in New Zealand/Aotearoa 1950-2000, (Wellington: Victoria University Press, 2009).

Hunter, Margaret L., Race, Gender and the Politics of Skin Tone, (New York: Routledge, 2005).

Jha, Meeta Rani, The Global Beauty Industry: Colourism, Racism, and the National Body, (Oxford: Taylor \& Francis, 2015).

Livesay, Daniel, Children of Uncertain Fortune: Mixed-Race Jamaicans in Britain and the Atlantic Family, 1733-1833, (Chapel Hill: North Carolina Press, 2018).

Metge, Joan, Rautahi: The Maori of New Zealand, (London: Psychology Press, 2004).

Mitira, Tiaki Hikawera, Takitimu, 2nd ed. (Wellington: Reed Publishing, 1972).

Moon, Paul, Encounters: The Creation of New Zealand, (Auckland: Penguin Books, 2013).

Moorfield, John C, Te Aka Māori-English, English-Māori Dictionary and Index, 3rd ed. (Auckland: Longman/Pearson Education, 2011).

Morris, Grant, Prendergast: Legal Villain? (Wellington: Victoria University Press, 2014).

Obama, Barack, Dreams from My Father, 2nd ed. (Melbourne: Text Publishing Melbourne Australia, 2009).

O’Malley, Vincent, The New Zealand Wars: Ngā Pakanga o Aotearoa, (Wellington: Bridget Williams Books, 2019).

O’Regan, Hana, Ko Tahu, Ko Au: Kāi Tahu Tribal Identity, (Wellington: Horomaka Publishing, 2001).

Penetito, Wally, What's Māori About Māori Education? (Wellington: Victoria University Press, 2010).

Platt, Una, Nineteenth Century New Zealand Artists: A Guide and Handbook, (Christchurch: Avon Fine Prints, 1980).

Pool, Ian, Te Iwi Maori: A New Zealand Population Past, Present and Projected, (Auckland: Auckland University Press, 1991).

Selby, Rachael, Still Being Punished, (Wellington: Huia, 1999).

Simon, Judith and Linda Tuhiwai Smith, A Civilising Mission? Perceptions and Representations of the Native Schools System, (Auckland: Auckland University Press, 2001). 
Smith, Phillipa Mein, A Concise History of New Zealand, (Cambridge: Cambridge University Press, 2012).

Sorrenson, M.P.K (ed.), Na To Hoa Aroha: From Your Dear Friend: The Correspondence Between Sir Apirana Ngata and Sir Peter Buck, 1925-50, Volume 1: 1925-29, (Auckland: Auckland University Press, 1986).

Sorrenson, M.P.K (ed.), Na To Hoa Aroha: From Your Dear Friend: The Correspondence Between Sir Apirana Ngata and Sir Peter Buck, 1925-50, Volume 3: 1932-50, (Auckland: Auckland University Press, 1989).

Thomson, Arthur S., The Story of New Zealand: Past and Present - Savage and Civilized, Volume 2, (London: John Murray, 1859).

Walker, Ranginui, Ka Whawhai Tonu Matou - Struggle Without End, (Auckland: Penguin, 1990).

Wanhalla, Angela, In/Visible Sight, (Wellington: Bridget Williams Books, 2009).

Wanhalla, Angela, Matters of the Heart, (Auckland: Auckland University Press, 2013).

Williams, Melissa Matutina, Panguru and the City: Kãinga Tahi, Käinga Rua: An Urban Migration History, (Wellington: Bridget Williams Books, 2016).

\section{Journal Articles:}

Austin, Tony, 'Cecil Cook, Scientific Thought and 'Half-Castes' In the Northern Territory 1927-1939’, Aboriginal History, Vol. 14, no. 1, 1990, pp. 104-122.

Ballantyne, Tony, 'Paper, Pen, and Print: The Transformation of the Kai Tahu Knowledge Order', Comparative Studies in Society and History, Vol. 3, no. 2, 2011, pp. 232260.

Biggs, Bruce, 'Maori Affairs and the Hunn Report', The Journal of Polynesian Society, Vol. 70, No. 3, September 1961, pp. 361-364.

Derby, Melissa and Sonja Macfarlane, 'How High is your RQ?' Is Te Reo Māori the New Blood Quantum?', Te Kaharoa, Vol. 11, no. 1, 2018, pp. 219-221.

Harper, Marjory, 'A Century of Scottish Emigration to New Zealand', Historical Studies in Ethnicity, Migration and Diaspora, Vol. 29, no. 2, 2011, pp. 220-239.

Jones, Trina, 'Shades of Brown: The Law of Skin Color', Duke Law Journal, Vol. 49, 2000, pp. 1487-1557.

Kukutai, Tahu H, 'White Mothers, Brown Children: Ethnic Identification of Maori-European Children in New Zealand', Journal of Marriage and Family, Vol. 69, no. 5, 2007, pp. $1150-1161$.

Lachance, Paul, 'The Formation of a Three-Caste Society: Evidence from Wills in Antebellum New Orleans', Social Science History, Vol. 18, no. 2, Summer 1994, pp. 211-242.

Mahtani, Minelle, 'What's in A Name? Exploring the Employment of 'Mixed Race' as an Identification', Ethnicities, Vol. 2, no. 4, 2002, pp. 469-490. 
Mair, Laura M, 'They 'Come for a Lark': London Ragged School Union Teaching Advice in Practice, 1844-70', Churches and Education, Vol. 55, June 2019, pp. 324-346.

McCabe, Jane, 'Working the Permit System: Anglo-Indian Immigration to New Zealand, 1920-1940', New Zealand Journal of History, Vol. 48, no. 2, 2014, pp. 27-49.

Mikahere-Hall, Alayne, 'Constructing Research from An Indigenous Kaupapa Māori Perspective: An Example of Decolonising Research', Psychotherapy and Politics International, Vol. 15, no. 3, October 2017, pp. 1-14.

Mitnick, Eric J., 'Law, Cognition, and Identity', Louisiana Law Review, Vol. 67, no. 3, September 2007, pp. 823-869.

Moeke-Maxwell, Tess, 'Bi/Multiracial Maori Women's Hybridity in Aotearoa/New Zealand', Discourses: Studies in the Cultural Politics of Education, Vol. 26, no. 4, 2005, pp. 497-510.

Moon, Paul, “To Teach the Natives English”: James Pope's 1880 Native Schools Code', History of Education, Vol 48, no. 5, 2019, pp, 591-606.

Nystrom, Justin, 'In My Father's House: Relationships and Identity in an Interracial New Orleans Creole Family, 1845-1875', Louisiana History: The Journal of the Louisiana Historical Association, Vol. 49, no. 3, 2008, pp. 287-313.

O’Malley, Vincent, 'A Tale of Two Rangatira: Rewi Maniapoto, Wiremu Tamihana and the Waikato War', Journal of the Polynesian Society, Vol. 125, no. 4, December 2016, pp. 341-357.

O'Regan, Tipene, 'Old Myths and New Politics. Some Contemporary Uses of Traditional History', The New Zealand Journal of History, Vol. 26, no. 1, 1992, pp. 5-27.

Paterson, Lachy, 'Hāwhekaihe: Māori Voice on the Position of 'Half-Castes' within Māori Society', Journal of New Zealand Studies, Vol. 9, March 2010, pp. 135-156.

Phinney, J.S., 'Ethnic Identity in Adolescences and Adults: Review of Research', Psychological Bulletin, Vol. 108, no. 3, 1990, pp. 499-514.

Phoenix, Aisha, 'Colourism and the Politics of Beauty', Feminist Review, Vol. 108, no. 1, 2014, pp. 97-105.

Riddell, Kate, 'Improving' the Maori: Counting the Ideology of Intermarriage', The New Zealand Journal of History, Vol. 34, no. 1, 2000, pp. 80-97.

Ryan, Greg, 'Anthropological Football', New Zealand Journal of History, Vol. 34, no. 1, 2000, p. 60-79.

Salesa, Damon, 'Half-Castes Between the Wars: Colonial Categories in New Zealand and Samoa', New Zealand Journal of History, Vol. 34, no. 1, 2000, pp. 98-116.

Schwimmer, Eric, 'The Māori Hapu: A Generative Model', Journal of Polynesian Society, Vol. 99, no. 3, 1990, pp. 297-317.

Spolsky, Bernard, 'Reassessing Māori Regeneration', Language in Society, Vol. 32, no. 2, September 2003, pp. 553-578.

Stephenson, Maxine, 'Closing the Doors on the Maori Schools in New Zealand', Race, Ethnicity and Education, Vol. 9, no. 3, 2006, p. 307-324. 
Wanhalla, Angela, 'Interracial Sexual Violence in 1860s New Zealand', The New Zealand Journal of History, Vol. 45, no. 1, 2011, pp. 71.84.

Wanhalla, Angela, ' 'Modernizing' Māori Marriage in New Zealand', Journal of Religious History, Vol. 43, no. 2, June 2019, pp. 217-233.

\section{Chapter in Edited Collections:}

Borell, Belinda, 'Living in the City Ain't So Bad: Cultural Identity for young Maori in South Auckland', in James H. Liu, Tim McCreanor, Tracy McIntosh and Teresia Teaiwa (eds.) New Zealand Identities: Departures and Destinations, (Wellington: Victoria University Press, 2005), pp. 191-206.

Doerr, Neriko Musha, 'Beyond 'Mixed Race' and 'Unmixed Race', Being and Having Race in Aotearoa/New Zealand' in Kirsten McGavin and Farida Fozdar (eds.), Mixed Race Identities in Australia, New Zealand and the Pacific Islands, (New York: Routledge, 2017), pp. 213-226.

Fozdar, Farida and Maureen Perkins, 'Antipodean Mixed Race: Australia and New Zealand', in Rebecca C. King-O’Riain, Stephen Small, Minelle Mahtani, Miri Song, Paul Spickard (eds.), Global Mixed Race, (New York: NYU Press, 2014), pp. 119-143.

Hall, Stuart, 'Cultural Identity and Diaspora' in Jonathan Rutherford (ed.), Identity: Community, Culture, Difference, (London: Lawrence \& Wishart, 1990), pp. 222-237.

Hunter, Margaret, The Consequence of Colorism', in Ronald E Hall (ed.), The Melanin Millennium: Skin Color as $21^{\text {st }}$ Century International Discourse, (Dordrecht: Springer, 2013), pp. 247-256.

Johnson, Patricia and Leonie Pihama, 'What Counts as Difference and What Differences Count: Gender, Race and the Politics of Difference', in Kathie Irwin and Irihapeti Ramsden (eds.), Toi Wāhine: The Worlds of Māori Women, (Auckland: Penguin Books, 1995), pp. $75-86$.

Kowal, Emma, 'Descent, Classification and Indigeneity in Australia', in Kirsten McGavin and Farida Fozdar (eds.), Mixed Race Identities in Australia, New Zealand and the Pacific Islands, (New York: Routledge, 2017), pp. 19-35.

O' Sullivan, Vincent, 'Joseph Jenner Merrett' in Roger Robinson and Nelson Wattie (eds.), The Oxford Companion to New Zealand Literature, Online Version, (Oxford: Oxford University Press, 2006). Web. Accessed 27 Aug. 2019, from https://www.oxfordreference.com/view/10.1093/acref/9780195583489.001.0001/acref $-9780195583489-\mathrm{e}-802$.

Pihama, Leonie, 'Kaupapa Māori Theory: Transforming Theory in Aotearoa', in Leonie Pihama, Sarah-Jane Tiakiwai, and Kim Southey (eds.), Kaupapa Rangahau: A Reader, (Hamilton: Te Kotahi Research Institute, 2015). Web. Accessed 27 Aug. 2019, from https://www.waikato.ac.nz/_data/assets/pdf_file/0009/339885/Kaupapa-RangahauA-Reader_2nd-Edition.pdf.

Robinson, David, 'Social Capital and Voluntary Activity: Giving and Sharing in Māori and Non-Māori Society', Social Policy Journal of New Zealand, Vol. 17, December 2001, pp. 52-71. 
Simon, J. (ed.), L. Smith, G. Smith, S. McNaughton, K. Matthews, W. Smith, L. Pīhama I. Hēperi, V. Tuteao, Ngā Kura Māori: The Native Schools System 1867-1969, (Auckland: Auckland University Press, 1998), p. 2.

Spolsky, Bernard, 'Māori Lost and Regained', in Allan Bell, Ray Harlow, Donna Starks (eds.), Languages of New Zealand, (Wellington: Victoria University Press, 2005), pp. 67-85.

Wanhalla, Angela, 'The Politics of 'Periodical Counting': Race, Place and identity in Southern New Zealand', in Tracey Banivanua Mar and Penelope Edmonds (eds.), Making Settler Colonial Space, (London: Palgrave Macmillan, 2010).

Wanhalla, Angela, 'Rethinking 'Squaw Men' and 'Pakeha-Maori': Legislating White Masculinity in New Zealand and Canada, 1840-1900', in Leigh Boucher, Jane Carey, Katherine Ellinghaus (eds.), Re-Orienting Whiteness, (New York: Palgrave Macmillan, 2009).

\section{Theses and Other Papers:}

Callister, Paul, Robert Didham and Deborah Potter, 'Ethnic Intermarriage in New Zealand', Working Paper, Statistics New Zealand, 2005.

Jenkins, Kuni, 'Becoming Literate - Becoming English, A Research into The Beginnings of English Literacy Within Maori Society', Monograph, University of Auckland, 1993.

Moeke-Pickering, T, 'Maori Identity Within Whanau: A Review of Literature', Working Paper, University of Waikato, New Zealand, 1996.

Wanhalla, Angela, 'Transgressing Boundaries: A History of the Mixed Descent Families of Maitapapa, Taieri, 1830-1940', PhD Thesis, University of Canterbury, 2004.

\section{Web:}

Alex Denney, 'Unknown Mortal Orchestra \& Taika Waititi on New Zealand Culture', Dazed, 5 April 2018; accessed 26 July 2019. URL: https://www.dazeddigital.com/music/article/39590/1/unknown-mortal-orchestraruban-nielson-taika-waititi-interview

Cameron, Graham, 'The Cruelty Behind Willie Jackson's Attack on Paula Bennett's Māori Identity', The Spinoff, 6 May 2019; accessed 10 May 2019. URL: https://thespinoff.co.nz/atea/06-05-2019/the-cruelty-behind-willie-jacksons-attack-onpaula-bennetts-maori-identity/

'Census Timeline 1840-1859', Statistics New Zealand Archive Site, edited 25 March 2013; accessed 25 June 2019. URL: http://archive.stats.govt.nz/Census/2013-census/infoabout-the-census/intro-to-nz-census/history/Timeline/Census\%20timeline\%2018401859.aspx

'Census Timeline 1900-1949', Statistics New Zealand Archive Site, edited 25 March 2013; accessed 25 June 2019. URL: http://archive.stats.govt.nz/Census/2013-census/infoabout-the-census/intro-to-nz-census/history/Timeline/Census\%20timeline\%2019001949.aspx 
'Early New Zealand Statutes and Ordinances 1841-1940', The University of Auckland New Zealand; accessed 2 August 2019. URL: http://www.enzs.auckland.ac.nz/

Hayden, Leonie, 'How to Tell If You're Māori', The Spinoff, 4 January 2019; accessed 10 May 2019. URL: https://thespinoff.co.nz/atea/04-01-2019/summer-reissue-how-to-tell-ifyoure-maori/

'A History of Census Taking in New Zealand', Statistics New Zealand Archive Site, 2013; accessed 25 June 2019. URL: http://archive.stats.govt.nz/Census/2013-census/infoabout-the-census/intro-to-nz-census/history/history-summary.aspx

'Maori Have Been Let Down by Census Botch-Up", Stuff, 15 August 2019; accessed 26 August 2019. URL: https:/www.stuff.co.nz/national/politics/opinion/114986288/mori-havebeen-let-down-by-census-botchup

Te Arawa Lakes Trust: https://tearawa.iwi.nz/; accessed 1 July 2019. 